a $\frac{\text { SPORT \& SCIENCE }}{\text { SON THE }}$
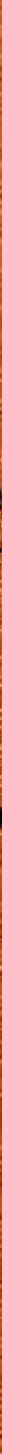

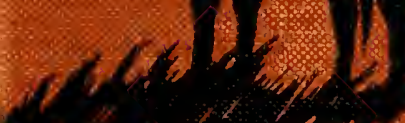

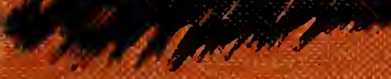





SPORT AND SCIENCE ON THE SINO - MONGOLIAN FRONTIER 




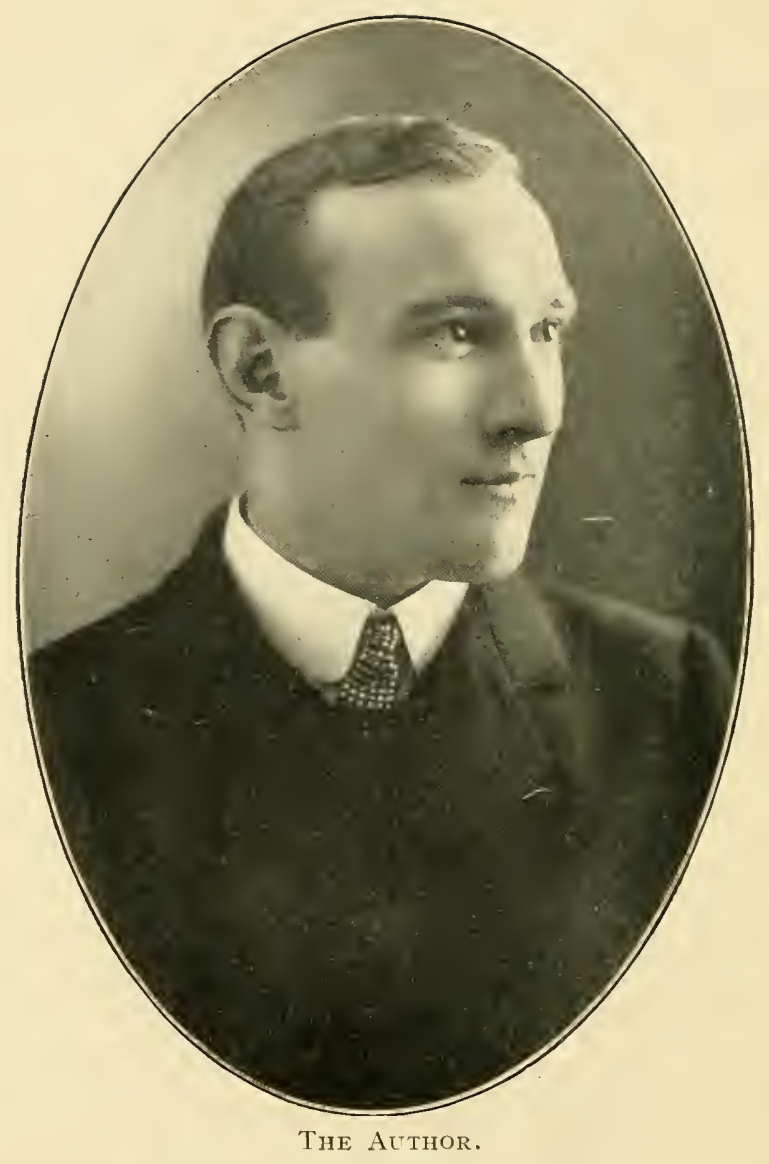

Frontispiece. 


\section{SPORT AND SCIENCE} ON THE

SINO-MONGOLIAN FRONTIER

By

ARTHUR DE CARLE SOWERBY, F.Z.S., F.R.G.S.

Joint Author with Robert S. Clark of "Through Shên-Kan," and Author of "Fur and Feather in North China" and "A Sportsman's Miscellany"

"Till a voice, as bad as Conscience, rang interminable changes On one everlasting Whisper day and night repeated-so :

'Something hidden. Go and find it. Go and look behind the RangesSomething lost behind the Ranges. Lost and waiting for you. Go!",

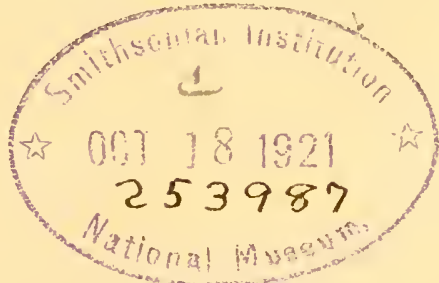

K1PLING.

LONDON : ANDREW MELROSE, LTD.

3 YORK STREET, COVENT GARDEN, W.C. 
To

MAJOR ROBERT STERLING CLARK,

In memory of many happy days' hunting on the Sino-Mongolian Frontier. 


\section{Introduction}

GVER since the Original Hundred Families wandered eastward from Central Asia into the land now known as China, and settled in the broad and fertile valley of the Wei River in the present province of Shensi, forming the nucleus of the Flowery Kingdom, its people have been harassed continually by the ravaging hordes of Tartary.

The frontiers between the two races, one peaceful and addicted to the practice of the Arts, the other warlike, and caring only for plunder, rapine and conquest, have always been marked by scenes of bloody conflicts, ruthless raids and brutal massacres ; yet, strange though it may seem, it has been the peaceful nation which has won in the end, and continually the Sino-Mongolian boundary has been pushed further to the north.

The Chinese have repeatedly been conquered by the Tartars, and subjected to a rule of tyranny and oppression; but it has always ended in the same way-either the absorption or the ejection of the Tartar conquerors, and a further advance of the Chinese upon the acknowledged territories of these predatory Nomads. 


\section{INTRODUCTION}

From the Wei valley, occupied twenty centuries before the Christian era, the Chinese, themselves an invading race, driving out or exterminating the aborigines, spread steadily eastward and northward, till, in the reign of the illustrious Shih Huang-ti, the boundaries of the Empire were marked by the Great Wall. This for many centuries divided the actual territories of the Chinese from those of the Mongols, in spite of further invasions and conquests on the part of the latter; that is to say, the dwellers on the south side of the Wall remained Chinese and those on the north Mongol, regardless of the nationality of the ruling Emperor.

This state of affairs was maintained up to the middle of the nineteenth century, when as the Tartar Power, both Manchu and Mongol, Eastern and Western, gradually declined, the Chinese pushed beyond the Wall, settling further and further out on the Mongolian Plateau. This was not done by force of arms, but by intrigue and purchase, and it has led to much bitterness and ill-feeling on the part of the Mongols.

To-day, we again have before us the old drama, being played in much the same old way. The Chinese have risen, have shaken off the enfeebled Tartar yoke, and are endeavouring to add yet another portion of Mongolia to the ever-increasing domains of the Middle Kingdom.

The aggression of the New Republic, whose 


\section{INTRODUCTION}

rights over Mongolia are only such as she may maintain by force-Mongolia having been tributary to the Manchu and never to the Chineseis naturally resented by the Mongolians. Thus we see armed bands of both nations lining the present frontier, in many places far beyond the Great Wall, while we hear of depredations and incursions made by wild undisciplined horsemen, who swoop down from the grassy plain or sandy desert to burn, plunder and kill, returning whence they came before the slow-moving Chinese troops can offer resistance, or strike an effective blow in return.

The most recent political boundary between Mongolia and China, that is the one extant before the declaration of Mongolian Independence in September 1911 and the present ensuing complications, extended from the border of Manchuria near Liao-chou in the province of Fêng-t'ien in a west-south-westerly direction north of Lama Miao (Dolon Nor) to the north-eastern corner of Shansi province. Thence bearing more to the south, it kept north and west of K'uei-hua-ch'êng, till it reached the Yellow River near He-k'ou. From here it followed the course of that river, running due south as far as the north-eastern corner of Shensi province. From this point on it coincided with the course of the Great Wall, extending into the heart of Asia, and terminating only with the western boundary of Chinese Turkestan. 


\section{INTRODUCTION}

Westward from the point where it strikes the Yellow River near He-k'ou this boundary is the natural one, being marked, first by a section of the river, then by the sandy edges of the Ordos Desert, next by a second stretch of the Yellow River, and finally by the southern border of the Gobi Desert.

Eastward from He-k'ou it is more difficult to trace a natural boundary, as the whole country is broken up by irregular ranges of hills and mountains interspersed with wide river valleys, which in some instances assume the dimensions of plains.

On the whole the course of the outer loop of the Great Wall may be said to define most satisfactorily the natural boundary. Especially is this the case immediately north and north-west of Kalgan, where a line of high cliffs of volcanic origin marks the edge of what is generally known as the Mongolian Plateau.

From Kalgan the Wall runs first east and then, after making a big loop to enclose the valley of Pei Ho, turns south-east, following the crests of the mountain ranges, finally ending abruptly on the sea coast at Shan-hai-kuan (lit. Mountain-sea pass).

The line of demarcation between the land actually occupied by the Mongols on the one hand and the Chinese on the other follows the political boundary, but, so far as the writer has been able to observe, the floral and faunistic, as well as the 


\section{INTRODUCTION}

geologic boundaries coincide with the natural one, excepting only that part extending from Kalgan to Shan-hai-kuan. Here the faunistic and floral boundaries undoubtedly lie far more to the north, coinciding rather with the political boundary.

In the present volume the term "Sino-Mongolian Frontier" indicates not so much the political boundary as here set forth, but rather the boundary marked out by Shih Huang-ti when he built the Great Wall, which as already stated defines to a great extent the natural boundary.

The subject of this book is a series of explorations, carried out by the author accompanied in each case by at least one other European, through districts, which, lying in close proximity to the Great Wall, may be included in the title as already defined.

The work carried out on these explorations was in the nature of scientific and geographical research, including the collection of biological specimens, the making of geological notes, the carrying out of compass traverses, and the general investigation into the lives, customs and conditions of the natives.

These explorations were as follows :-

1. A journey through North Shensi, the Ordos Desert and Western Shansi, by Malcolm $\mathbf{P}$. Anderson and the author in connexion with the Duke of Bedford's Exploration ix 


\section{INTRODUCTION}

of Eastern Asia; Spring and Summer 1908.

2. An expedition through the upper basin of the Fên River in Western Shansi, by the author and his wife; Winter, 1909-10.

3. Short collecting trips round T'ai-yüan Fu, Shansi ; Autumn 1911.

4. A shooting trip in the mountains north-east of Kalgan; February 1912.

5. A journey from Kalgan to K'uei-hua-ch'êng in North Shansi ; Spring, 1912.

6. A journey in Inner Mongolia; Summer, 1912.

It may be noted that the Clark Expedition, which forms the subject of Through Shên-Kan, took place between the first and second of the explorations enumerated above, and the present book may be considered supplementary to that work.

Chapters dealing with the scientific aspects of the work of the several expeditions are given at the end of this book. An itinerary, which, it is hoped, will be found useful by future travellers in these parts is also given.

The results of the compass traverses have been

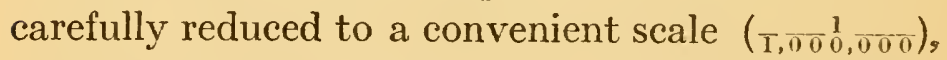
and maps will be found in the cover-pocket at the end of the book.

I am indebted to Mr. Malcolm P. Anderson for photographs illustrating the first of the series of explorations, to MIr. Robert S. Clark for others 


\section{INTRODUCTION}

of North Shensi, and to Dr. P.H. Atwood, who is the best big game shot in North China, for those of the wild boar and the leopard.

My best thanks and appreciation are due to Mr. Frederick W. Warrington, who at his own expense accompanied me on the last two expeditions, rendering the ablest assistance.

\section{ARTHUR DE C. SOWERBY.}

\section{NOTE}

This book was written in 1913, but on account of conditions brought about by the European War, which broke out on the eve of publication, it was thought advisable not to issue it till now.

On the whole conditions in China and Mongolia are much the same to-day as they were in 1913 , with the exception, perhaps, that the suzerainty of China over Mongolia has been re-established, while the threat of annexation by Russia has, for the time at least, been removed. Intermittent fighting still takes place between the Mongols and Chinese, but this partakes more of the nature of raids by lawless bands than direct military conflict between the two countries.

The railway from Kalgan westward has been completed as far as Fên-chêng (see page 105) on its way to K'ueihua-ch'êng, thus reducing the journey a day's march.

The effect of the recent outbreak of pneumonic plague in this region has not yet been made known, but since the whole of the area from Fên-ehêng westward was affected, it is certain that the population, already sparse enough, has been further reduced. It has been reported that whole villages have been wiped out by this terrible disease.

1918.

A. DE C. S. 



\section{TABLE OF CONTENTS}

PAGE

INTRODUCTION

CHAPTER I

'The Ordos Border . . . . . . . 3

CHAPTER II

The Forests and Lakes of tile Fên Ho Basin · 39

CHAPTER III

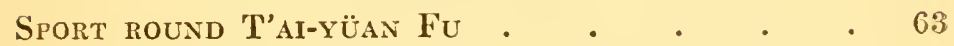

CHAPTER IV

Trip to Hsi-wan-tZŬ . . . . . . 83

CHAPTER $V$

Journey to K'UEI-HUA-Ch'ÊNG : the 'T'AI HAI • 101

CHAPTER VI

After Argali and Wapiti . . . . . 113

CHAPTER VII

The Mongolian Plateau $\quad . \quad$. $\quad$. $\quad$. 139

CHAPTER VIII

Biological Work . . . . . . . 173

\section{CHAPTER IX}

The Flora of the Sino-Mongolian Frontier • 215

i. Trees . . . . . . . . 216

(a) Gymnosperms . . . . . . 218

(b) Angiosperms . $\quad \cdot \quad \cdot \quad \cdot \quad \cdot \quad \cdot 221$ 


\section{CONTENTS}

ii. Fruits • • . . . . . . 226

iii. Flowers . . . . . . . 237

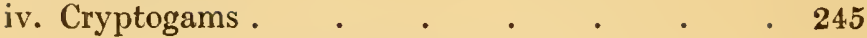

\section{CHAPTER X}

Geological Notes . • • • • • . 251

Part 1.-The Geology of the Country traversed by

the Chên-T'ai Railway, Western Chihli and Eastern Shansi . . . . . . 253

Part 2.-The Geology of the Country traversed by

Anderson and the Author in 1908, Northern

Shansi, the Ordos and Western Shansi . . 258

Part 3.-The Geology of the Upper Fên Ho Basin,

Western Shansi . . . . . . 263

Part 4.-The Geology of the Country traversed by the Peking-Kalgan Railway, North Chihli ～. 268

Part 5.-The Geology of the Ch'ing Ho and Hsiwan-tzŭ District, North Chihli . . . 270

Part 6.-The Geology of the Country traversed by

the Ch'ang-sui Extension Line, North-Western

Chihli and North-Eastern Shansi 272

Part 7.-The Geology of the Country from Yang-

kao to K'uei-hua-ch'êng, North Shansi 273

Part 8.-The Sedimentary Rocks north-west of Pi-ch'ien-ch'i, North-Western Shansi ～. . 276

Part 9.-The Geology of the Mongolian Plateau,

Inner Mongolia . • • • • . 278

Appendix; Itineraries . . . . . . . 283 


\section{LIST OF ILLUSTRATIONS}

PLATE

FACING

PAGE

The Author

Frontispiece

I. Yen-an Fu, looking up the Yen-shui . . 6

II. Cave Dwellings near Yen-an Fu . . . 14

III. Idols in Temple Cave, near Yen-an Fu. . 30

IV. Leopard (Felis fontanieri) shot by Dr. P. H.

Atwood in Shansi . . . . . 42

Wild Boar (Sus sp.) shot by Dr. P. H. Atwood in Shansi. Weight, $330 \mathrm{lb}$. . . . 42

V. Mr. and Mrs. A. de C. Sowerby with Bag of Wild

Pigs, Bustards and Small Game . $\quad 58$

Water-Mill in Winter . . . . . 58

VI. Hunting Party on Summit of High Peak, near Tái-yüan $\mathrm{Fu}$. . . . . . 72

Front View of North China Wild Pig, shot at

Shêng-yieh, near Tái-yüan Fu . • . 72

VII. Crossing the Yellow River . • . 88

Yen-ch'uan Hsien, North Shensi . • . 88

VIII. The Author and his Big Ram, photographed where it fell . . . . . . 114

IX. Mongol Women wearing Full Dress Headgear of Silver-Mounted Coral and Turquoise . . 142 Mongol Woman in Ordinary Headgear . . 142

X. Procession leaving Prayer Hall, Lama Miao, Mongolia . . . . . . . 154 


\section{LIST OF ILLUSTRATIONS}

PLATE

FACING

XI. Big Prayer Wheel, Lama Miao, Mongolia . 160 Devil-dancers, Lama Miao, Mongolia . $\quad 160$

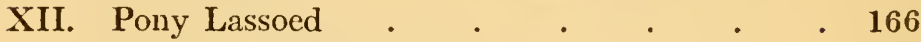

A Herd of Mongol Ponies . . . . 166 Watehing the Races $\quad . \quad$. $\quad . \quad 166$ Breaking a Wild Pony . . . . 166 Examining Teeth of Wild Pony . . . 166 Branding Wild Pony . . . . . . 166

XIII. Giant Hamster (Cricetulus triton incanus) . 180 Young Antelope . . . . . . . 180 Wild Sheep. . . . . . . 180

XIV. Mink (Mustela sibirica) Eating Teal . . 192 Golden Eagle $\quad . \quad$. $\quad$ • $\quad$. $\quad$. $\quad 192$ Ruddy Sheld-Duck . . . . . $\quad$. 192

XV. Wild Peach in Blossom near Yen-an Fu. March 226

XVI. Wild Peach Blossom (Amygdalus davidiana) near Yen-an Fu. Late March . . . 238

XVII. A Tower of the Great Wall, Ordos Border . 258 Loess Ravine in North Shensi . . . 258 
THE ORDOS BORDER 



\section{CHAPTER I}

\section{THE ORDOS BORDER}

$\mathrm{V}$

ERY early in life my travels began. I was only four years old when my parents took me from an interior town of China to the coast, and thence to Europe. Vaguely I remember the mule train "coughing in the dust" of a Shansi road, and the house-boat journey down a Chihli river, with my mother lying at death's door in the cramped and tiny cabin, overcome by that cruel journey. Then came the strange sights and scenes of the sea journey to England, followed by the even stranger (to me) life of my native land. Three years later we were back again in the interior town, and from that time on I have scarcely lived in one place longer than a year or two at a time.

All this doubtless accounts for my love of travel, which has led to my kicking the traces and becoming a wanderer. What more natural than that the wandering should have for its scene the land of my nativity, where I know the people and their language, where I can live, if necessary, 


\section{SPORT AND SCIENCE ON THE}

upon the land, without the help of stores from Europe or American canned goods? What more natural than that the unknown places in this land of mystery should beckon to me, and that I should hear that voice ringing its "interminable changes .... something hidden. Go and find it. ...."?

I cannot claim with Kipling's Explorer to have found country unknown to man; but I can say that I have been the first white man to tread many a forest and wild mountain, many a sandy waste and boulder-strewn wilderness, many a rich pasture and fertile valley. I, too, have seen the promise of future prosperity in "the big fat marshes that the virgin ore-bed stains," in the " nameless timber," and "illimitable plains."

Will others go up and occupy? Will my countrymen aid in developing that potential wealth ? I hope so.

Strange though it may seem it has not been the solemn grandeur of the great back ranges, nor the mysterious silence and gloom of the virgin forests, nor yet the smiling fatness of the valleys and plains that have appealed to me most. It is the sun-baked, barren ridges, the shifting, windswept sand-dunes and the saline, brackish swamps of the Ordos Desert that have cast upon me the strongest spell.

Even as a boy I had been fascinated by what I had heard of that howling wilderness, that 


\section{SINO-MONGOLIAN FRONTIER}

waste of sand, that "Never-never country." The romance of those wild Tartars, living their lives of untrammelled freedom always appealed to my imagination and I longed to go and see it all.

At last the chance came, and never shall I regret the step that once and for all settled my destiny, when I exchanged a town life of comparative ease for that of the explorer and collector.

It was in Tientsin in the summer of 1907 that I first met Mr. Malcolm P. Anderson, who was out in the East collecting mammals and specimens of zoological interest generally for the British Museum at South Kensington, in connexion with the Duke of Bedford's Exploration of Eastern Asia.

At the time I was engaged in mounting the fruits of a hunting and collecting trip in Western Shansi for a local museum.

With common interests a friendship sprang up between us, which culminated a month or so later in a decision to join forces in carrying out an expedition into the hitherto practically unknown Ordos Desert.

As I would not be free till the end of the year Anderson went to T'ai-yüan $\mathbf{F u}$ in Shansi, where he continued to collect, till, everything having been arranged satisfactorily, I joined him towards the end of January 1908.

The proximity of the Chinese New Year pre- 


\section{SPORT AND SCIENCE ON THE}

vented our starting for another fortnight, but at last on February 10, we set out from T'ai-yüan Fu with a somewhat meagre equipment of four mules and one pony, together with three natives.

A glance at the map of China will suffice to show the reader the position of the Ordos Desert. It is situated within a mighty loop of the Yellow River immediately north of Shensi, from which province it is divided by the Great Wall. The Ordos is known to the Chinese as Ts'ao-ti (grass land), and the only information we could glean concerning it was that it was an immense wilderness of sand and coarse scrub, in which wild Tartars lived, and where hardy races of small ponies and cattle were bred.

This sounded interesting, though hardly favourable to our purpose of making a large collection. Nevertheless our instructions were definite on the subject, so we set about attaining the end in view as best we could.

We found that by travelling due west we could have reached $\mathrm{Yü}$-lin $\mathrm{Fu}$ on the border of the desert in fourteen days, but this would have brought us to the country at a time of year when the weather would have been most unsuitable for the collecting of small mammals, and much valuable time would have been wasted.

We therefore decided to travel south-west to Yen-an Fu in North Central Shensi, and from there work north-west, to the southernmost point 
PLATE I.

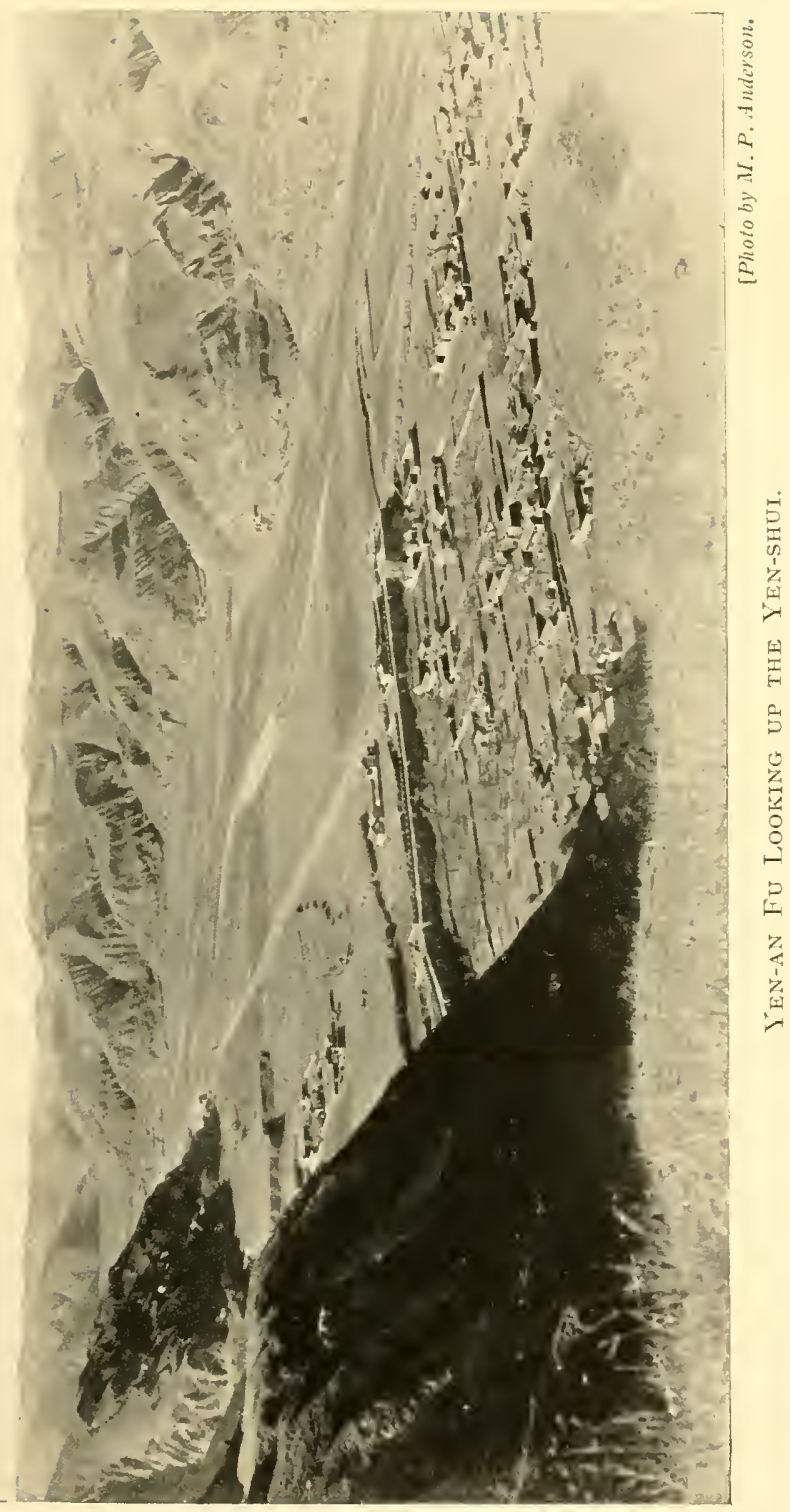





\section{SINO-MONGOLIAN FRONTIER}

of the Ordos. By stopping and collecting at a few places along this route, we would gauge our arrival on the frontiers of the desert to sometime in spring, the best season for our work.

After leaving T'ai-yüan $\mathrm{Fu}$, and crossing the low mudfiats of the Fên River, our road lay in a south-westerly direction through well cultivated country. Round the villages we noticed innumerable jujube trees (Zizyphus sativa), which grow extensively in all the low lying valleys and plains of Shansi, Chihli and Shensi. The fruit of these trees resembles nothing so much as a date, and when treated with honey makes an excellent preserve. It is largely used in the manufacture of sweetmeats, especially of the cheaper qualities, while bread-steamers ${ }^{1}$ use it instead of currants in the manufacture of a kind of bun loaf.

Our first stopping place was the small torw of Chin-ssŭ, famous for its temple and spring. The latter gushes out of the base of the hill upon which the temple is built, and irrigates the surrounding fields, making the cultivation of rice on a large scale possible.

It also forms the motive power of a number of paper mills, a coarse straw-paper being manufactured in the district.

The temple of Chin-ssǔ is a very beautiful edifice, composed as it is of magnificent buildings

${ }^{1}$ In north China, excepting in Kansu, the best bread is steamed, and goes by the name of " Chêng mo." 


\section{SPORT AND SCIENCE ON THE}

standing upon a series of stone terraces running up the steep hillside. A long flight of stairs extends from the base to the topmost shrine, while in the extensive grounds are artificial lakes, filled with carp. Old and stately trees stand here and there, the most interesting of which are two huge Maidenhair trees (Gingko biloba).

We reached Fên-chow $\mathrm{Fu}$ two days later, passing on our way the important towns of Chiaoch'êng Hsien and Wên-sui Hsien. The country between these two places is noted as being the finest grape producing district in China. The grapes grown are mostly purple, but some white varieties occur. In the season these fruits sell at less than one halfpenny per pound.

Fên-chou Fu itself is a large business town with an extensive floating population. It has nothing of particular interest to recommend it to the traveller, who is only too anxious to get away from its dirt and smells.

On leaving this town we took a westerly course, and following a deep and narrow gorge in the limestone formation, crossed a high divide at its head.

We spent the night at a large village named Wu-ch'êng. From here we turned southward, and after travelling fifteen miles, stopped at a place named Shi-shi-ling, situated in a mountainous and well-wooded district. Here we remained for some days hunting and collecting. 


\section{SINO-MONGOLIAN FRONTIER}

Wild boars, leopards and roe-deer were seen, but we were too busy trapping for small mammals to pay much attention to large game.

Pheasants, partridges and hares were abundant, and kept our pot well filled. The weather was too severe for good work, and beyond a few squirrels, field-mice, small hamster rats and three or four species of birds we secured very little.

The country was typical of Shansi, consisting of rugged shale and limestone mountains, overgrown with scrub oak, hazel, birch, wild peach, conifers and thorny shrubs of various kinds.

From Shi-shi-ling, we travelled westward towards the Yellow River, putting up at Ninghsiang Hsien, and Liu-lin-chên on February 24 and 25 respectively. The former of these two places is a town of no importance and less interest. At Liu-lin-chên some fine springs, open all the year round, form a winter resort for countless wildfowl, including teal, mallards, sheld-ducks, golden eyes and mergansers.

On February 26 we crossed the Yellow River and put up at a small village on its right bank. The crossing was effected by means of large ferry boats, into which mules and baggage were ignominiously bundled, when, with long, roughly made oars, the ferrymen kept the boats at angles such that the swift current forced them along in the desired direction. In consequence, the landing 


\section{SPORT AND SCIENCE ON THE}

was effected some considerable distance down stream.

Continuing westward over barren wind-swept loess ridges for two days, we reached a busy little town named Sui-tê Chou. Thence we travelled southward for four days along a splendid road, which had recently been cut by the Yü-lin Fu garrison. This country was very desolate, consisting as it did at that season of bare loess hills inhabited only by occasional coveys of partridges and a few foxes and eagles.

At a place called Yen-ch'uan Hsien, not far from some recently opened oil wells, we turned westward, and after crossing a steep loess pass, entered the valley of the Yen-shui, the river on whose banks is situated the old town of Yen-an Fu. All the towns and villages we passed were in a sad state of ruin, while the inhabitants were terribiy poverty-stricken. The country has not yet recovered from the devastating effects of the great Mohammedan rebellion of the sixties, followed in $\mathbf{1 8 8 7}$ by a protracted famine. It is true that the greater part of the loess hills is under cultivation, but years must elapse before the country regains its former prosperity. ${ }^{1}$

1 In the winter of 1911 , the writer again visited this district, as leader of the Shensi Relief Expedition.

The effects of the Revolution, which has been described as being "synonymous with anarchy in Shensi," were only too painfully evident. The year's crops were still standing. 


\section{SINO-MONGOLIAN FRONTIER}

Near Yen-an $\mathrm{Fu}$ we noticed that there were many dense thickets, consisting chiefly of the thorny wild jujube (Zizyplus sativa spinosa) along the Yen-shui valley, so we decided to stop and spend a few days in collecting. Our efforts met with immediate success, so that we prolonged our stay in the vicinity. We secured one new species and three new sub-species of rodents, besides several already well-known forms.

Each morning ere it was light we would sally forth with satchel and shot-gun to inspect our traps, set the night before. Bringing in the specimens secured, we would spend the rest of the day till mid-afternoon in skinning and preparing our day's haul, after which we would once more go out to look over the traps, or set new ones.

The new species referred to above was a pika (Ochoton abedfordi), a small rabbit-like rodent,

Many villages along the high road were deserted, such of the inhabitants as had escaped death having betaken themselves to hastily built stockades in the highest loess hills, while the towns were continually menaced by robber hordes and lawless bands of the dreaded Ko Lao Hui (Elder Brother Society).

Since that date no word of the prevailing conditions in North Shensi has reached the outside world, but it is highly probable that the already scanty population has been still further reduced by sword and famine, and that large stretches of country under cultivation at the time of the writer's first visit to this district, now lie a wilderness - a refuge for the increasing coveys of game, and a hiding place for robber bands.-A. DE C. S. 


\section{SPORT AND SCIENCE ON THE}

while the new sub-species were a sulphur-bellied rat (Epymys confucianus luticolor), a large hamster rat (Cricetulus triton incanus), and a hare (Lepus swinhoei subluteus). The kindred forms of the last three species are found in the Shantung Peninsula and in Chihli.

The abundance of game and small mammals round Yen-an-Fu is undoubtedly due to the extensive thickets of wild jujube in the vicinity. This plant, wherever it occurs, forms excellent cover for pheasants, hares, small mammals and birds. It grows usually in the form of low shrubs, and is thickly covered with strong sharp thorns, some of which are straight, and others hooked. The result is that large animals and human beings experience great difficulty and inconvenience in traversing thickets of this growth. The fruit, which has a pleasant sour taste, together with the hard stony kernels, forms a regular part of the autumn and winter diet of the smaller mammals and birds. One of the characteristics of this peculiar plant is that it never grows at an altitude exceeding 3,000 ft. above sea level, and another is that it comes into leaf long after all other plants in the same districts in which it grows.

We were told by the natives that there were some very good collecting grounds about ten miles south-west of Yen-an Fu. Accordingly we packed our traps and visited the spot. We were rewarded by finding excellent country, both for shooting 


\section{SINO-MONGOLIAN FRONTIER}

and trapping, so that our collection began to reach pleasing proportions.

This country we found to consist of the usual loess hills, but they were thickly covered with scrub and rapidly extending woods of birch, hazel and poplar.

In some places the hillsides were covered with wild peach (Amygdalus davidiana), which was now in full bloom, and presented a wonderful sight. This peach is supposed to be the original stock from which all our many varieties have been derived. This however is not at all certain, as wild peaches have been found in other parts of Asia. It is very hardy, withstanding extremely low temperatures. The fruit is small and worthless as a table delicacy, though it is greatly appreciated by squirrels and other rodents.

The tracks of wild boars, roedeer, leopards and wolves were frequently seen, while pheasants were particularly plentiful.

Some interesting birds were secured, amongst which were a large and handsome blue magpie (Urocissa sinensis), and the sweet-voiced timeline (Pomatorhinus gravivox). A single specimen of the grey-headed plover (Microsarcops cinereus), a large and elegant member of the family, was shot in one of the stream beds.

The weather was now wonderfully mild, so that our thoughts began to turn towards the sandy stretches of the Ordos, and finally on April 6, 


\section{SPORT AND SCIENCE ON THE}

after once more reaching Yen-an $\mathrm{Fu}$, we set out in a north-westerly direction along the Yen-shui valley.

We were somewhat reassured as to the prospects of securing food for ourselves and our animals in the Ordos, the natives of Yen-an Fu having informed us that there were plenty of Mongols, who were well off and hospitable, scattered in little encampments at easy stages in every direction.

The journey up the Yen-shui proved uneventful except that as we neared the end of the valley on the third day, we had to cross the river no less than sixty-eight times. Towards the end of the afternoon, however, it began to dwindle down till it was no longer of formidable dimensions and crossings were easily effected.

As the day wore on we noticed that the loess hills were growing higher and higher, while the substratum of rock changed from grey to red sandstone. Through this the stream cut deeply, forming sheer and lofty cliffs on either side.

In one place we noticed, high up on the face of the cliff, some cave dwellings, which were reached by a series of stakes driven into the face of the rock. Many of these were missing, from which we concluded that the caves had long remained untenanted.

The natives of our last stopping place told us that here we would find a good-sized village with 
PLATE II.

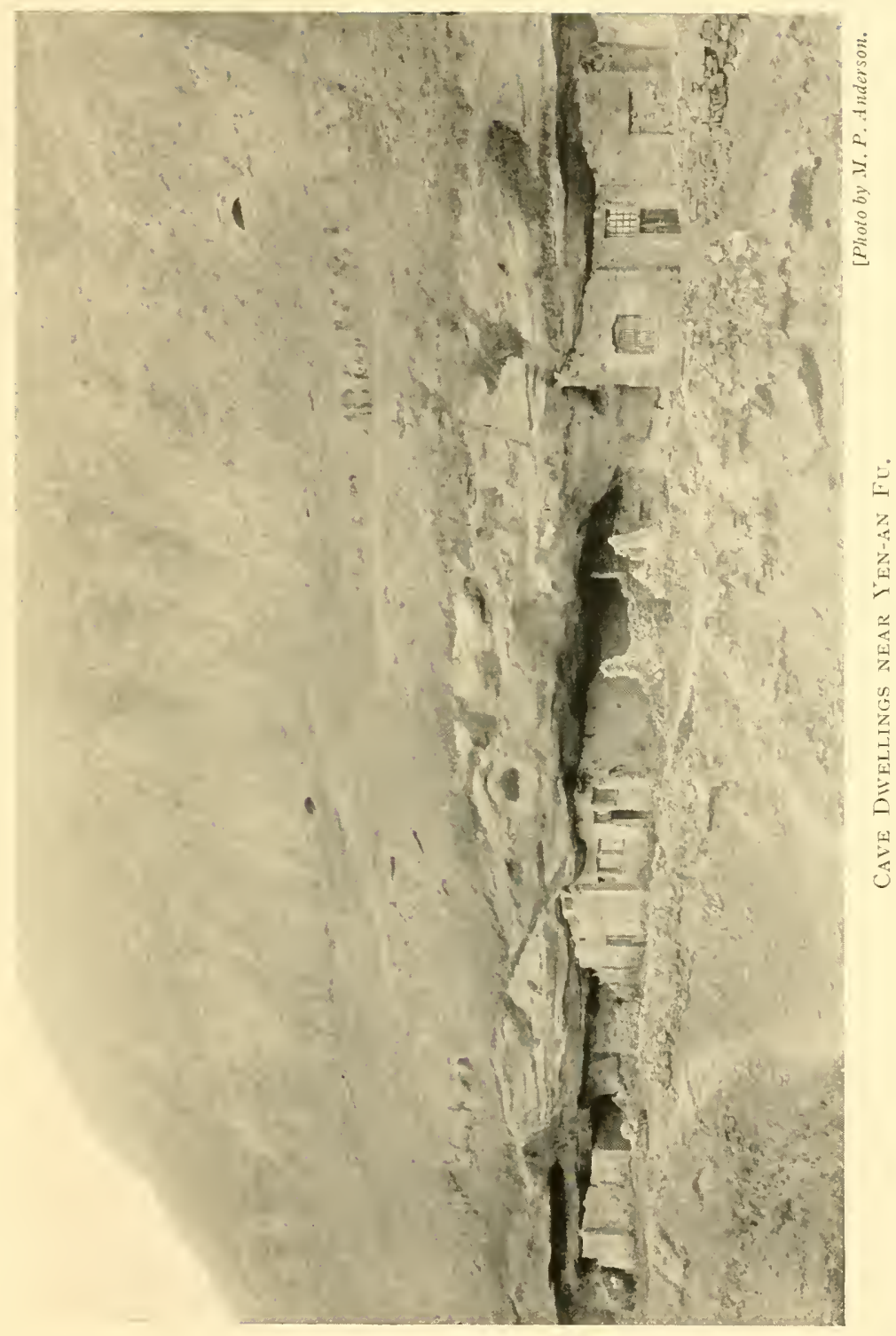

opposite p. I4]. 



\section{SINO-MONGOLIAN FRONTIER}

plenty of accommodation. This turned out to be a purely malicious and unprovoked falsehood, for when night began to descend our little party found itself in a desolate and seemingly uninhabited wilderness.

Following the only bridle path we began a long and difficult ascent till we reached an altitude of 6,000 feet, having climbed over 3,000 feet since leaving Yen-an Fu. The path now led along the top of a rugged ridge and became momentarily more difficult, till, darkness overtaking us, we realized that we were hopelessly lost. To make matters worse, a cold north wind sprang up, cutting us to the bone.

We wandered aimlessly along for two hours, discussing the advantages or otherwise of making a tentless camp where we were, without fuel for a fire, food for ourselves, fodder for the mules, or even a drop of water.

Just as we were about to unload the mules a voice hailed us from the darkness, and the welcome barking of dogs told us that we were near some human habitation. To our joy we found not fifty yards from us a cluster of huts, including an inn, surrounded by a high mud wall. The latter had effectually hidden the lights of the huts, and but for the vigilance of the innkeeper we should have been condemned to spend the night exposed to hunger, thirst and a bitter north wind. The following day we pursued our course over 


\section{SPORT AND SCIENCE ON THE}

steep mountain peaks, down frightful chasms and treacherous cliffs, and over wastes of sinking sand, but at last we reached Ching-pien Hsien, a small garrison town within a mile of the Great Wall, and the longed for Ordos Desert.

However pleased we might be at having reached our goal we were nevertheless far from comfortable. The weather had turned very cold again; nothing but the very poorest food was obtainable. The air was filled with fine sand, which got into our eyes, scrunched between our teeth, and stung our faces as it was driven by the cruel north wind.

“. . . I think never saw

Such starved ignoble nature; nothing throve : For flowers-as well expect a cedar grove! But eockle, spurge, according to their law Might propagate their kind, with none to awe, You'd think; a burr had been a treasure-trove.

As for the grass, it grew as scant as hair In leprosy ; thin dry blades prieked the mud Which underneath looked kneaded up with blood."

The utter dreariness and desolation of the surrounding country, together with the poverty and wretchedness of the inhabitants, combined to depress and harass our spirits, which were only restored to their normal condition by the assurance that the country beyond the Wall was much better. We made a short excursion as far as the Wall, and climbing one of the isolated towers, obtained our first view of the Ordos. 


\section{SINO-MONGOLIAN FRONTIER}

A wide expanse of sand, thickly studded with trees gave promise of better things in store.

On the following day, April 11, we lost no time in leaving behind us the miserable town of Chingpien, and for some miles travelled northward through a country that grew more promising with each succeeding step. Flocks of stately cranes fed on the stretches of reddish sand, while innumerable trees, chicfly willows, arranged in long rows, relieved our eyes, after the days of barren wastes we had endured.

In crossing a deep ravine, just after leaving Ching-pien, we nearly lost one of our mules with its precious burden, comprising our only stores, in some deadly quicksands. It was only a miracle that saved the animal. As it was much of our food got wet, and some of it was rendered useless.

That evening we reached the end of the broad belt of trees, and put up at a small farmstead named Ning-t'ieh-liao, which we were surprised to find was owned by Chinese.

We learnt that the Chinese here, and elsewhere along the Ordos border, are gradually pushing further and further into the Mongol territory.

By planting rows of trees they prevent the drifting and piling up into dunes of the loose shifting sand. They manage thus to grow crops of millet, such areas as they do not cultivate producing a coarse grass. This with the leaves 


\section{SPORT AND SCIENCE ON THE}

of the willows forms the chief food for their flocks of sheep and goats.

We spent April 12 at this farmstead, drying out our stores and exploring the immediate vicinity. We found that the river that flows past Ching-pien continues northward into the desert, subsequently turning eastward and flowing back into Chinese territory.

Being anxious to see something of the Mongols themselves we left Ning-t'ieh-liao the following day, taking a northerly direction.

We were told that the Tartars lived some twelve miles away, and that it would be necessary to hire a guide to lead us across a difficult stretch of sandhills. We therefore engaged the services of a stupid yokel, who had accompanied us from Ching-pien, and who claimed to know some of the Mongol families.

We soon left behind us the belt of willows, and passing a small lagoon, from which Anderson secured a fine grey-lag goose, we entered the dunes. Considerable difficulty was experienced with the mules, whose small hoofs sank deep into the sand. Spills were frequent. Once all four mules were down together, piling one atop of the other as they rolled down a more than usually steep slope. Great confusion followed, and it was only with the greatest care that animals and loads were extricated without serious damage. 


\section{SINO-MONGOLIAN FRONTIER}

We also found going very difficult and tiresome, owing to the looseness of the sand.

At last after we had passed through a belt of tall scrub, there opened out before us a long and broad stretch of grass land dotted over with lagoons and marshes. As we approached these we noted vast numbers of waterfowl of every description. Grey-lag geese and sheld-ducks wandered in pairs between the tussocks of coarse grass in search of food. Flocks of stately cranes and lordly bustards waded knee deep in the marshes, or fed upon the grassy meadows. Teal and ducks of every variety blackened the surface of the lagoons, while plovers flapped heavily overhead uttering their plaintive calls.

Scattered far and wide over the plain were innumerable herds of ponies and cattle, the property of the Mongols whose huts and tents we could see on the opposite edge of the grassland.

We made our way across to one of these huts, where we interrogated the goodwife, who was brought to the door by the barking of some savage and wolfish looking dogs. She refused us shelter on the ground that she could not supply our mules with the necessary fodder.

IVe passed on to the next hut and met with a similar reception. At last after trying several farmsteads we reached a newly built, two-roomed hut, enclosed in a neat willow fence, and, unload- 


\section{SPORT AND SCIENCE ON THE}

ing our mules we refused to proceed any further.

Finding that these border Mongols could speak Chinese fluently, $\mathbf{I}$ went into the hut to discuss with the owners of the place, a newly married couple, the much vexed question of quarters for ourselves and fodder for our mules.

The Mongols were polite, and offered us shelter for one night only, this being the custom. More they dared not do, or they would be held responsible for our actions. It was plain that they were suspicious of us, and my explanation that we were collecting small animals only seemed to deepen their suspicions. Evidently they had not yet experienced the eccentricities of white men.

At last we decided to take what we could get, and as we could not bring ourselves to sleep in the hut with the natives, we put up our beds inside the willow fence.

We were next invited to take some salted tea, in which parched millet was steeped. This was not very palatable, but was better than nothing.

The hut was built after the manner of those occupied by the poorer Chinese, and, as already stated, was enclosed by a high willow fence. There were also stables and storehouses built of willow stems plastered over with mud. The confines of our hosts' property were marked by a low mud wall, about two feet high, outside which was a ditch of corresponding depth. 


\section{SINO-MONGOLIAN FRONTIER}

A well, some six feet in depth, supplied the residents and their cattle with water, that of the lagoons in the district being too brackish for either man or beast. Even the wells were far from sweet.

Outside and opposite the gate of the enclosure was a long pole stuck into an immense wicker basket filled with sand. From a crosspiece near the top of the pole depended several pieces of white and red calico, while the end of the pole was adorned with a tuft of dry grass. The whole contrivance formed a sort of totem pole, having something to do with the religious ceremonies of the owners. We noticed one of these poles outside every Mongol hut or tent.

The tents of these Mongols were of the usual pattern-wooden framework covered with coarse felt, usually of a black colour.

We soon found that these people were intensely superstitious, practising a sort of demon worship. Everywhere, they said, were malign spirits, which must not be offended. Thus I was called sharply to book, when I inadvertently sat upon the coping of the mud fireplace. It was insulting the "fire demon." Again, as we approached one of the huts, the muleteers led their animals across the low boundary wall, when an old woman rushed out and cursed us roundly, while her daughter tore the bells off the mules. Completely discomfited by the vigorous onslaught we retired 


\section{SPORT AND SCIENCE ON THE}

in disorder, afterwards learning that some religious function in connexion with the birth of a child was in progress, and the ringing of the bells within the confines of the farmstead would attract evil spirits.

At one place we were refused admission on the ground that they were having a spring cleaning of devils, and if we entered we would assuredlybring some with us. Even at the place where we did secure quarters our baggage was left outside the enclosure long enough for the demons it contained to escape.

Our hostess on finding a snake inside the mud wall very carefully carried it outside, and refused to let us have it for a specimen, saying that it would not do to offend the snake spirit.

For the rest these people are Buddhists, one or more of the sons in each family becoming lamas.

In physique the Ordos Mongols are superior to the Chinese. They are a tall well built race, admirably fitted to wrest a living from the cruel desert in which they live. The women are good looking, some even beautiful, while their lives in the open give them a grace of carriage together with a strength and freedom of movement never seen inside the Wall. They can ride barebacked, and with the ease and grace of a cowboy, the shaggy and wicked little ponies that they rear upon the surrounding grasslands.

They wear a peculiar headdress of silver-mounted 


\section{SINO-MONGOLIAN FRONTIER}

coral and turquoise beads, surmounted by a gold embroidered cap, while their hair falls over their shoulders in two thick strands. The rest of their ordinary attire is similar to that of the men, which is the usual Manchu dress-baggy trousers and long coat or gown of blue surmounted by a large sleeveless waistcoat of some bright colour. Only in the absence of buskins does the women's dress differ from that of the men.

On gala days, which the women celebrate equally freely with the men, the former sport silk robes of the most gorgeous and vivid colours, and even the latter manage to don clothes of gayer hues.

They are a light-hearted, cheery people, always on the look-out for fun, and always playing jokes upon one another.

As already stated a large proportion of the men are lamas, who have their heads shaved and wear long robes of red or yellow, with sashes of the same colours. These priests are supposed to be celibate, but we saw several with large and flourishing families.

The food of these Mongols consists in winter of mutton and beef, but in summer they live almost entirely upon parched millet, which to render palatable they steep in salted tea. The millet, a poor and coarse variety, they grow themselves.

For fuel they depend almost entirely upon the droppings of their cattle, which when dried they 


\section{SPORT AND SCIENCE ON THE}

call " argol." Camel "argols" are undoubtedly the best fuel of this nature.

While setting some traps in the willow scrub that fringed the grasslands, dividing them from the wastes of sand beyond, we noticed great numbers of hares, which, as dusk came on, left the sheltering bushes, and froliced or fed upon the meadow land. We also saw a few pheasants and partridges.

Next day, having brought in our traps and packed our baggage we loaded the mules, and were about to start, when up rode a well dressed old man, wearing a mandarin's hat and blue button, and accompanied by two attendants. Jumping from his pony he saluted us, producing a crucifix to show that he belonged to the true faith. After exchanging civilities we told him of our difficulty in finding quarters. He at once gave us permission to stay where we pleased as long as we chose. Our erstwhile hosts promptly offered us further hospitality, but with such a charter as we now had we preferred to go further in search of better collecting grounds and more commodious quarters. The old chief offered us rooms in his own home, which he said was at a place named Borrobalgosun some twenty miles westward. Accordingly we set out together in that direction and soon were engaged in friendly conversation.

We found that our new friend thought that we were Catholic priests, of which religion he was a convert. On finding that we were not even 


\section{SINO-MONGOLIAN FRONTIER}

missionaries of any other sect, he changed his attitude towards us. He was still polite, but less bonhomme and presently he withdrew his invitation to stay at his home.

However he promised to find us quarters elsewhere, and excusing himself on the plea that he had some business to attend to, set his pony at a gallop and was soon out of sight, leaving us to follow as best we could.

At last after passing several more farmsteads, we came to a cluster of huts, outside which our friend awaited us. We were well received, being at once shown into a spare room, and offered salted tea and millet.

Mr. Bluebutton introduced us to our host, and all arrangements were made for a stay of some days, after which, said he, we would be welcome to Borrobalgosun. Things having thus been arranged to his entire satisfaction, the chief bade us a hearty farewell, and with his minions rode away into the west.

We at once set about making ourselves as comfortable as possible. We got out our traps, but met with little success. The only things caught were specimens of ground squirrels (Citellus mongolicus) and two varieties of gerbils (Meriones unguiculatus and $M$. auceps), together with the hare.

An attempt to secure some antelopes failed, though quite a number were seen. Specimens of a snake (Coluber dione) and two lizards (Phryno- 


\section{SPOR'T AND SCIENCE ON THE}

cephalus frontalis and Eremias argus) were added to the collection. Besides the waterfowl and game birds already mentioned, wheatears and larks seemed to be the only feathered denizens of these sandy wastes.

The scarcity of animal life was a great disappointment to us, and we decided to waste no more time in this locality. The muleteers came to us complaining that they could get no grain for their mules, while very little fodder was to be had. The obstinate animals refused the coarse alkaliimpregnated herbage that grew around. Our own stores also were sadly diminished, and we were told that we would not fare better by going to Borrobalgosun, where nothing but parched millet was to be had.

Under these circumstances we decided to head for $\mathrm{Yü-lin} \mathrm{Fu}$, where we could replenish our stock of provisions, and properly equipped could once more attempt to penetrate the desert.

Five days we travelled in a north-easterly direction across heartbreaking sand dunes. By the end of the first day we had left behind us the Tartar encampments, and found ourselves once more in country occupied by Chinese.

The villages we passed were few and far between and we suffered considerably from thirst and heat. The white sand reflected the blinding rays of the sun, which shone ever more fiercely, till our eyes ached and our faces scorched and peeled. 


\section{SINO-MONGOLIAN FRONTIER}

From time to time we crossed shallow rivers, all of which flowed in a south-easterly direction. They had cut down through the fifty feet or so of sand to bedrock, which consisted of the same red sandstone that we had noticed at the sources of the Yen-shui. At one place there was a wonderful natural arch spanning the river, over which the road lay.

On the third day, April 18, we reached a place named Hai-liu-t'u-ho, where we secured the first specimen of the Ordos jerboa (Dipus sowerbyi).

Herbage of any sort was very scarce, dwarf willows, a coarse grass and a sort of sage brush composing the sparsely distributed thickets.

In one or two places we came across a species of conifer, which grew in thick clusters amongst the sand hills, and which we found to be very resinous, burning furiously even when quite fresh and green.

April 19 we spent at Hai-liu-t'u-ho in the hope of securing some more jerboas. Two more were brought in by the natives. That day a terrible sandstorm sprang up, so that when we set out the following day there was no sign of a road. We could not hire a guide as the people refused to have anything further to do with us. A baby and a cow had died in the village during our stay, and the superstitious natives looked upon us as the cause of these disasters.

The consequence was that we soon went astray. 


\section{SPORT AND SCIENCE ON THE}

Another sandstorm commenced, and before long we were hopelessly lost. For hours we wandered over the dunes with blinded eyes and sand-choked lungs, but at last we found a desolate looking farm, the owner of which we induced by promise of reward to set us on the right road once more. This he did, and we were able to keep to it by following some newly made tracks.

The following day we reached Yü-lin Fu, a large border town, situated on the bank of the Yü-lin Ho, some three miles south of the Great Wall. Here we found comfortable quarters, and thankful we were to escape for a time the allpervading sand.

We at once set about making plans for another trip into the Ordos, but first we decided to offer money for specimens. A notice to the effect that the foreigners were willing to buy wild animals was put up at the South Gate, where all the country people and market gardeners would see it.

Within a few days we reaped a rich reward, so much so that we abandoned any idea of making another journey into the desert. Jerboas, hedgehogs, hamster rats, molerats, chipmunks and ground squirrels were brought in in great numbers. Of these the jerboa (Dipus sowerbyi), the hedgehog (Erinaceus miodon) and the sand hamster (Phodopus bedfordice) proved to be new species, while the chipmunk (Eutamias asiaticus ordinalis) was a new sub-species. Besides these a fine 


\section{SINO-MONGOLIAN FRONTIER}

badger (Meles leptorhynchus) and a wild cat's skin were purchased.

One day we visited a peculiar fort guarding a gate in the Great Wall, through which once passed the high road between Yü-lin Fu and Pao-t'ou, a large town on the northern border of the Ordos. The fort consists of three massive blocks of masonry built one upon the other. The largest at the base measures ninety feet square, while the whole edifice is about ninety feet high.

The Wall all along the Ordos border has crumbled away, leaving little more than a slight ridge. The watch towers which are situated at intervals of about three hundred yards, are, however, intact and serve still to mark the boundary line. It is obvious that the Wall in these parts was not faced with brick.

Yü-lin $\mathrm{Fu}$ is a prosperous military town with some seven thousand inhabitants. It is supposed to maintain a garrison of one thousand men to overawe the Mongols. Its walls are in good repair, and enclose many elegant temples. Like all the other border towns that we passed Yü-lin $\mathbf{F u}$ is for ever threatened with inundation by the vast sea of sand that rolls in from the north and west. But for the river that flows past its western wall the city would long ago have been submerged, and even now the officials are continually perplexed with the problem, as sand, sweeping round from the north, banks itself against the eastern wall in 


\section{SPORT AND SCIENCE ON THE}

many places right up to the battlements, forming an easy entrance for the belated traveller. We explored all the temples inside the city, but found nothing of extraordinary interest.

At length having made a sufficiently large collection, we decided to make a move, and on May 14 left the city by the East Gate, heading in a north-easterly direction. Gradually we approached the Wall, and did not lose sight of its grey towers till we were within a day's journey of the Yellow River and Shansi.

At intervals of about twelve miles we passed the dilapidated remains of small garrison towns now inhabited by a few poverty-stricken families. The country as we journeyed became more broken, and the mules had considerable difficulty in negotiating the steep slopes covered with drifts of sand. Towards the end of the first day we found ourselves on somewhat more elevated land, cut up in every direction by frightful chasms, which descended abruptly for hundreds of feet. Here our mules were momentarily threatened with destruction, as the path frequently led along the very edges of these precipices, and the loose soil continually broke away under their feet.

These chasms have certainly formed since the building of the Wall, for they frequently cut right across its length. To circumvent an unusually long one, we had to cross the Wall and make a long detour into the desert. 
PLATE III.

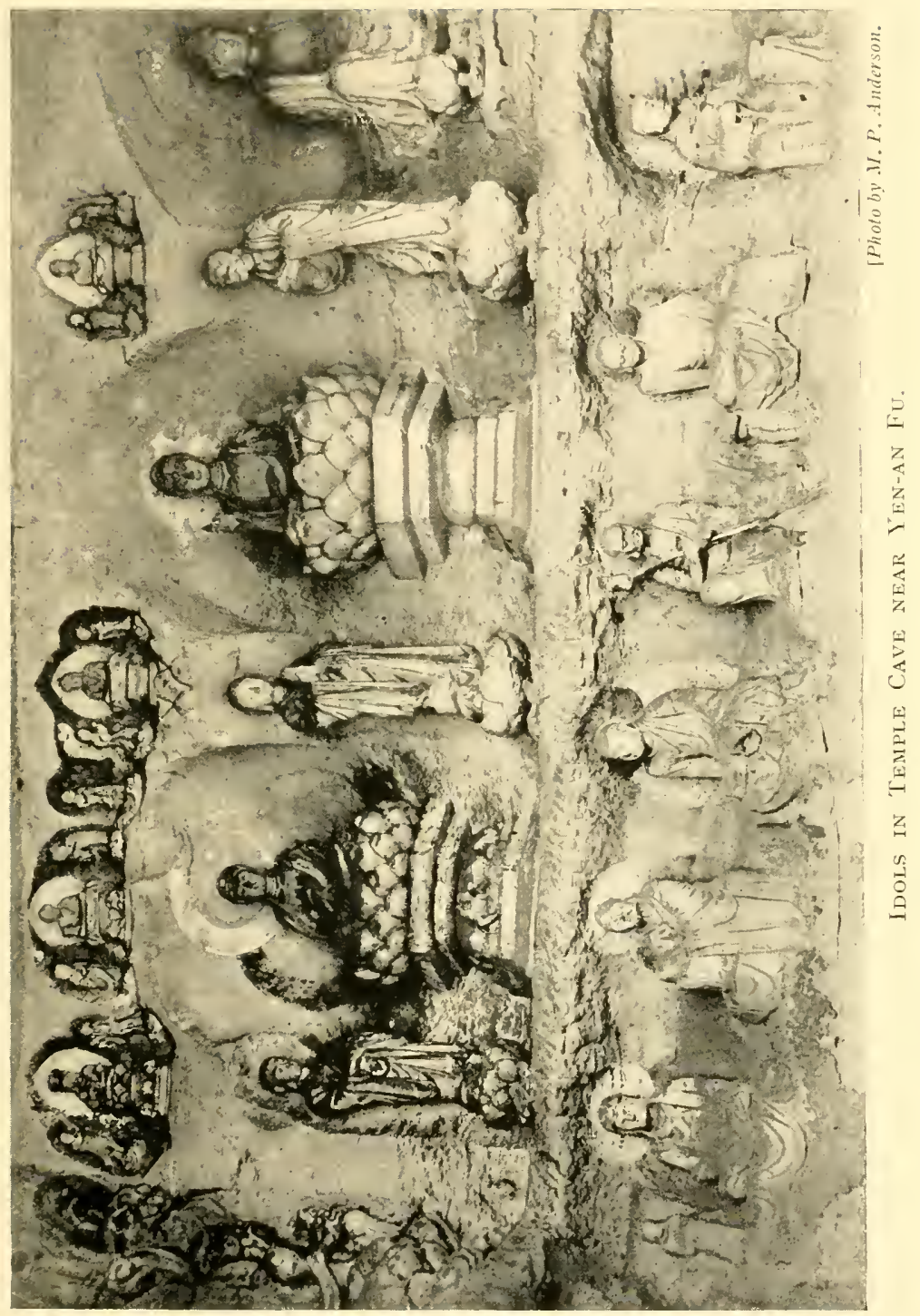

Opposite p. 30.] 



\section{SINO-MONGOLIAN FRONTIER}

That night we put up at an isolated inn called Tuan-ch'iang, situated beneath the shelter of the Wall, and on the edge of a chasm some five hundred feet deep.

The following day another long detour into the desert was made, and we stopped for our midday meal at a little village situated at the end of a ravine in the sand. A clear stream, springing from beneath the wall of sand at the end of the ravine flowed along its bottom irrigating some small fields of black clayey soil, which supported good crops.

We followed down the stream till we reached a river, along whose banks we travelled till we came to a fair-sized town named Kao-chia-pu, where we put up for the night.

A guide, whom we engaged, here told me that forty years ago, when he was a boy, the Mohammedan rebels crossed the Ordos from Ning-hsia in the west, and devastated the whole region. He distinctly remembered their entry into Kaochia-pu when they massacred all who did not escape into the surrounding hills.

The following day after a long hard march of some thirty miles we reached a large town named Shên-mu Hsien. We had now left behind us sand and loess, and were in hilly country composed mainly of sandstone.

On May 19 we descended from the high ground, and travelled down a long valley, making our 


\section{SPORT AND SCIENCE ON THE}

midday halt at a small place named Ku-shan-pu. My companion and I were some distance ahead of our mules when we entered the village, where a fair was in progress. Finding an inn we sought our usual rest from the noonday heat, but were soon disturbed by the crowd which became very aggressive.

I went out to pacify them and before I was aware of what was going on, found myself the centre of an angry mob. Cries of "Sa! Sa!" (kill, kill) assailed my ears, and the excited natives began to stone me. Convinced that my end had come, I resolved to sell my life dearly, but had no weapon save my bare fists with which to defend myself. I struck out right and left with all the force of desperation, feeling a grim pleasure as each successive blow laid one of my assailants low. At last my chance came. I was fighting towards a wall so as to gain protection for my back, which was being badly bruised, when the ringleader of the gang of desperadoes came for a moment between me and my goal. With all the force I could muster I let fly at his head, driving it with a thud against the wall. Down he went like a pole-axed ox and lay stunned. At this the mob broke up and fled. By now my temper was thoroughly roused and I resolved to teach those cowardly outlaws a lesson. Chasing the flying mob, I jerked two or three over onto their backs by sharp tugs at their outstretched queues. One 


\section{SINO-MONGOLIAN FRONTIER}

man in his haste to get away tumbled head foremost into a large earthen jar of water. The mob made a rush for the gate of the inn yard, where they were met by Anderson, who was returning, all aboil, from a sharp fight in the street. There in the gate we caught the twenty odd, now cringing, Chinese, and hammered them, till, in sheer desperation, they pushed past Anderson and fled up the street. We next cleared the street and then bruised, with bleeding knuckles, and torn clothes, but triumphant, we returned to the inn to secure our interrupted rest.

The end of the day found us at Fu-ku Hsien, on the banks of the Yellow River, and crossing in a ferry we put up at an inn in the suburb of Pao-tê Chow.

These two towns are situated on high loess hills facing one another on either side of the Yellow River, the passage of which they are supposed to hold against invading Mongols.

Neither of the towns is populous, but large suburbs have sprung up on the banks of the river below them.

At Pao-tê Chow we stayed for a few days collecting, but meeting with little success, we left the place and headed for a wooded area in the mountains some two days' journey to the south-east. Here we secured quarters at a farmstead situated at the top of a high loess ridge.

The surrounding country was well wooded and 


\section{SPORT AND SCIENCE ON THE}

we made excellent collections of voles, mice and hamsters. Two new voles (Microtus johannes and $M$. inez) were secured in this district. Some vipers (Ancistrodon intermedius) were also caught.

The forest and woods, which were rapidly being cut down, consisted mainly of spruce, larch and pine. The open hillsides at the time of our visit were ablaze with the rich yellow blossoms of the wild rose and the delicate mauve of the lilac. Some varieties of hawthorn and blackthorn were also noticed, while a species of wild pear (Pyrus $s p$.) was found growing on the hilltops. In places the ground was thickly covered with Solomon's seal, lilies and other flowering herbs.

The mountains themselves were composed of limestone, of the usual grey colour, covered in most places with thick deposits of loess and a very fertile soil. In spite of the abundant vegetation the district was very dry and drinking-water scarce. Daily our mules and those of our host had to make a six mile journey to secure water at a spring which was rapidly drying up, owing to drought, and the number of farms it supplied.

After a stay of ten days we moved on to K'o-lan Chou, a dilapidated town some three days' journey north-west of T'ai-yüan Fu. From here we travelled northward to Ning-wu Fu, passing Wutsai Hsien and Ch'ên-ch'êh Hsien on our way, both of which towns are situated on a wide plain stretching away to the Yellow River and Ordos Desert. 


\section{SINO-MONGOLIAN FRONTIER}

Neither of these towns is of much importance.

Ning-wu $\mathrm{Fu}$ is a poor looking city of no great importance. Its walls, temples and gate towers are in a sad state of disrepair. It is situated on the Hui Ho, a tributary of the San-kan Ho, near the source of the Fen Ho. The inner loop of the Great Wall passes from east to west about five miles to the north, and its towers may be seen from the city wall.

On a hill behind the city lie two very large tower-forts, long abandoned and allowed to crumble and decay.

The business quarter of the city is small and unimportant, showing how poor the inhabitants are. There is no special produce or manufacture, and but for the fact that the surrounding districts are governed from this city, it would doubtless cease to exist as such.

At Tung-tsai near Ning-wu Fu we collected a good series of molerats (Myospalax fontanus), chipmunks (Eutamias asiaticus intercessor) and pikas (Ochotona bedfordi). Of these the molerat, which was first identified as Myospalax fontanieri was new to science, while the chipmunk proving to be an intermediate form between the Chihli species (E. $a$. senescens) and that from the Ordos (E. a. ordinalis) was described as a new sub-species.

Single specimens of the little wood pika (Ochotona sorella) and the allactaga (Allactaga mongolica) 


\section{SPORT AND SCIENCE}

were secured. The former of these turned out to be a new species, and it is very rare.

On June 26 we left Ning-wu Fu, travelling in an easterly direction as far as a small town named T'ai-niu-tien, after spending the night at which place we continued as far as Hsin Chow in a south-easterly direction. From here two easy stages brought us to 'T'ai-yüan $\mathbf{F u}$ on June $\mathbf{3 0}$.

We had been away for five months, during which time we had not set eyes on a European other than ourselves, had completed a circuit of considerably over one thousand miles, and had made a collection of three hundred and fifty mammals including thirty-three species, twelve of which were subsequently described as new. Some dozen species of reptiles and batrachians were also secured, besides a small collection of birds. 
THE FORESTS AND LAKES OF THE FÊN HO BASIN 



\section{CHAPTER II}

THE FORESTS AND LAKES OF THE FEN HO BASIN

A FTER the Clark Expedition, described in A Through Shên-Kan, had been brought to a close in T'ai-yüan $\mathrm{Fu}$, I decided to continue the work of scientific exploration provided that funds were forthcoming and that I could find a suitable companion. Both conditions were soon fulfilled. My wife would make a more than suitable companion, while financial arrangements were made whereby I could carry on my work, sending the results to the Smithsonian Institution.

Returning to T'ai-yüan Fu from the coast, my wife and $I$ at once set about preparations for an extended journey up the valley of the Fên Ho, a large tributary of the Yellow River which flows from north to south down two-thirds of the western portion of Shansi province.

Before starting, however, we decided to do a little work in the immediate vicinity.

Accordingly we hired a cart and took our outfit on to the plain, pitching our tents about five 


\section{SPORT AND SCIENCE ON THE}

miles south of the city on the bank of the Fên Ho. Here we stayed for ten days, during which time I initiated my wife into the delights of camp life.

We spent the whole time trapping, shooting and riding. Geese, ducks, quail and hares were plentiful, and many were brought to bag. One day a bustard weighing about $16 \mathrm{lb}$. was brought down after a long and careful stalk through the underbrush.

Our traps yielded well, so that we made a very respectable little collection of mammals. It included specimens of the mink, the shrew, the vole, the giant hamster, Anderson's hamster, the gerbil and the common mouse.

We next moved up into the mountains east of T'ai-yüan Fu, called Lung-wang Shan, where we put up at a fine old temple. This place constitutes one of the summer resorts of the T'ai-yüan community, and is distant from that city about twenty miles.

The district is well wooded and is noted for its beautiful scenery, especially during the summer. The deep ravines are filled with cypress, firs and willows, while in places the rare white-barked pine (Pinus bungeana) grows in a wild state. The rocky watercourses at the ravine bottoms are filled with ferns, mosses and other cryptogams. Where these ravines widen out there are rich grass-plots, on which grow the orchis, the butter- 


\section{SINO-MONGOLIAN FRONTIER}

cup, the daisy, the forget-me-not and many other beautiful flowers.

The tops of the shale slopes are studded with bushes of the wild peach, the lilac and the yellow rose, all of which blooming in spring clothe the mountains with rich masses of blossom, and lade the air with delicate perfume. In autumn the rose bushes, which in themselves are more than usually ornate, with their red stems and spines, and minute pinnate leaves, are loaded with large sweet hips of a deep crimson colour.

Throughout the warmer months flowers of one sort or another lend their beauty to the scene, but it is in the autumn that the richest variety is seen. Then it is that the deep rich blue of the gentian, mingling with the delicate mauve of the scabious, the warmer tints of the vetches and trefoils, the golden yellow of the toadflax, the pink of the daisy, and the brilliant scarlet and orange of the lilies, presents a wealth of colour hard to surpass even in the tropics.

At the time of our visit all these floral glories were over, and the first nip of winter was making itself felt.

We collected here a few specimens of well known species of mammals, such as the sulphur-bellied rat (Epimys confucianus luticolor), the wood mouse (Apodemus speciosus) and the hamsters (Cricetulus triton incanus and $C$. andersoni).

On November 9 we returned to T'ai-yüan $\mathrm{Fu}$ 


\section{SPORT AND SCIENCE ON THE}

prepared to face all the rigors of winter travel through a practically unknown country.

This was no light undertaking for a woman used to all the comforts and luxuries of the European settlements in the East. We would be entirely dependent upon Chinese inns, often mere hovels, for shelter from the bitter cold, while, even allowing for a good supply of stores, the food must often be of the roughest. Nevertheless, my wife refused to be dissuaded by sympathetic but sceptical friends from her purpose of accompanying me.

We hired seven mules to carry our outfit, and engaged a groom, a cook and two boys to act as servants. We ourselves would travel on horseback, for which purpose I secured three good Mongol ponies.

Our outfit was as good as could be secured for the work in hand, and everything promised a successful trip.

On November 25 our little caravan left T'aiyüan $\mathrm{Fu}$ by the west gate, and crossing the Fên valley, we entered the mountains due west of the city.

Travelling very slowly, we followed the same route as that taken by the Clark Expedition as far as Ku-chao, thirty miles west of T'ai-yüan Fu. At this point we turned northward up the Fên Ho.

Journeying up the course of the river at this 
PLATE IV.

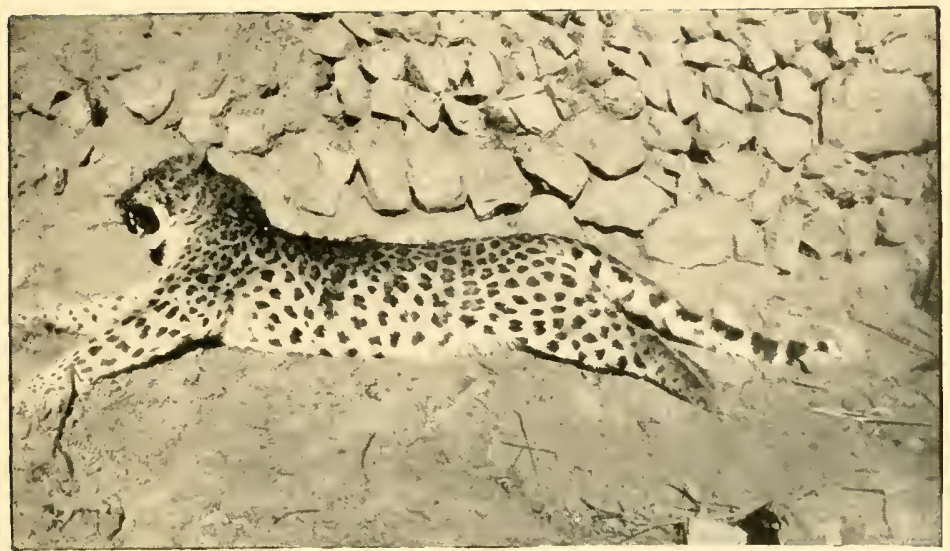

[Photo by P.H. Atwood.

LEOPARD (Felis fontanieri) SHOt BY DR. P. H. Atwood in SHANSI.

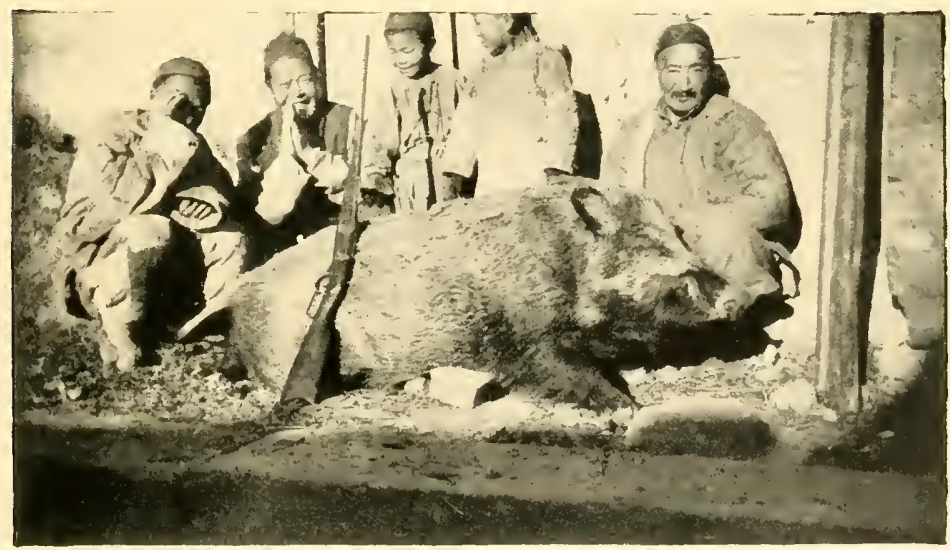

Photo by P.H Atwood

Wild Boar (Sus sp.) shot by Dr, P. H. Atwood in Shansi. Weight, 330 LBS.

Opposite p. 42.] 



\section{SINO-MONGOLIAN FRONTIER}

season was no light task. The precipitous sides forced us to keep to the bed, and the wide stream, flowing from side to side of the valley, necessitated frequent crossings. As it was in a semi-frozen condition, this was dangerous work. Once my wife narrowly escaped the horrible fate of being swept under the ice. It was only the agility of her pony in bounding clear of the breaking ice and rushing torrent that saved her.

More than once it was necessary personally to wade through the icy water in order to find a firm bottom for the passage of the mules and ponies. The natives neither dared nor could be trusted to do this, preferring always to allow the mules to take their chance of crossing with dry loads, while they themselves found safe passage where the ice would stand their weight.

On December 8, after one or two short halts en route to try and pick up a few specimens, or to check up the compass traverse, we reached Tsing-lo Hsien.

Here we stayed till December 14, while I tried to trap some pikas and wolves. I secured two of the former, but was unsuccessful with the latter.

Leaving Tsing-lo Hsien, we continued up the valley of the Fên Ho for another ten miles, when, after spending the night at Yung-an-chêng, we turned westward up a side valley, reaching a place named Wu-chia-kou at the edge of some magnificent forested country. Here we decided to 


\section{SPOR'T AND SCIENCE ON THE}

spend Christmas, as the surrounding country offered prospects of good hunting and trapping.

In this we were not disappointed. During our stay here we had a long line of traps out, which yielded well, while in pig-hunting we were very successful.

The first pig that was bagged was an enormous animal measuring six feet two inches from tip to tip, with a height of thirty-two inches at the shoulder and a weight of $310 \mathrm{lb}$.

For several days reports came in of a sounder of fifteen swine, led by an enormous white pig, the size of a cow. I made up my mind to get this fellow if possible. Several days were spent in fruitless search. Always on returning to camp I was told that the sounder had been seen in some valley other than the one I had been searching. At last one evening, as I was returning from a tiring day in the highest portion of the range, the villagers told me that not half an hour before, the sounder I had been hunting for had passed the village and had climbed the opposite ridge.

Tired as I was, I at once set off in the direction indicated, and there sure enough were the tracks I had grown so familiar with during the past few days. Following these up, I climbed the long ridge, and was just beginning to think that once more the pigs had eluded me, when one of the villagers who had accompanied me pointed across the ravine on my right. There, in a small field, 


\section{SINO-MONGOLIAN FRONTIER}

about a dozen pigs were feeding, but nowhere could I see the great white leader.

Thinking that I had better make sure of at least one pig, I began to cross the ravine, keeping under cover as much as possible. Just as I was near enough, and was about to aim, the great white leader came treading majestically round a small shoulder of rock. What a pig! He seemed to my excited imagination to be more the size of an elephant than a cow. On he came with nose up, scenting round for danger, while behind came several other pigs looking very small beside their magnificent leader.

Raising my rifle, I fired. The huge brute whirled round, stood for a second, and then broke madly up and across the ravine. Reaching the head he vanished from view. I hurried up the steep ravine, and reached the top of the ridge just in time to see my quarry rounding the head of a second ravine. Without waiting to regain my breath, I raised my rifle and fired. The pig continued his course for a few yards, and then suddenly plunged down the hill side. He struggled madly to keep his footing, but presently staggered and went head over heels, finally fetching up at the bottom of a small cutting, stone dead.

The following day I went in search of an old tusker, that had been wounded the day before by a Chinese hunter, and had subsequently met and knocked down one of my men, who was out 


\section{SPORT AND SCIENCE ON THE}

setting traps. We found the trail easily enough, but did not follow it up far, as it lost itself in a stony ravine bottom.

While trying to pick it up on the wooded slope, we ran across a very fresh trail and decided to follow it up at once. It led us across the top of the ridge, and a few yards down the next slope, which was covered with dense hazel scrub. As we entered the latter, there was the sound of some large body moving through the brush. Breathlessly we waited, soon being rewarded by the sight of a good-sized pig, rapidly climbing the opposite slope. I fired a couple of quick shots, but the pig gained and crossed the top of the ridge and vanished. We dashed down through the hazel scrub and up the steep slope. On reaching the top a spot of blood told us that our pig was hit. Continuing on the run we tracked him round the head of the next ravine, over the divide at the top, and once more drove him from the dense brush in which he was lying up. This time as he climbed the slope opposite us, I managed to get in a shot that bowled him over, but again he struggled to his feet and vanished over the crest of the ridge. Another arduous climb brought us into a small wood of scrub oak, where we found great difficulty in singling out the trail of our quarry from a dozen others that ran in all directions. Sending the hunter along one of the freshest, I followed another, which led along the 


\section{SINO-MONGOLIAN FRONTIER}

side of the ridge. Presently there was a splotch of blood in one of the footprints, and I knew that I was on the right scent. As I hurried along through the pines and larches, I presently became aware of my quarry standing amongst the trees some twenty yards above me. With gleaming eyes he stood looking down at me, but before he could make up his mind to charge, I dropped him with a bullet through the neck, just behind the ear.

The following afternoon we climbed a high range of jagged peaks that lies to the south of the village, our object being to catch the pigs as they left the cover of the forests for their feedinggrounds as dusk came on. Two hours' steady climbing through the most enchanting woodland scenery brought us to the crest of a knife-like ridge between two pointed peaks some 2,000 feet above the level of the valley bottom. Below us on the one hand lay the dark woods of pine and spruce, through which we had just climbed, on the other tier upon tier of the purple ridges of the foothills stretching away to the pink horizon.

Away across the valley to our north rugged ranges rose higher and higher, culminating in the massive granite peak of Lo-yah Shan, whose castellated summit caught the last pink rays of the setting sun, while its base lay shrouded in rapidly gathering mists and ever deepening shadows. 


\section{SPORT AND SCIENCE ON THE}

Nothing could surpass the beauty of the scene which we beheld that evening as we cautiously worked along the ridge, keeping a sharp look-out upon the cultivated fields a thousand feet below us, whereon we hoped to catch some early pig setting forth upon his night's depredations. We were disappointed, however, in not sighting any game, but the wonderful scenery more than compensated us for the arduous climb.

The next successful pig hunt, which was two days later, might well have proved disastrous for me. In climbing round some steep rocks, from the crevices of which sprouted some young spruce trees, affording me the necessary foothold, I surprised a sounder of eight pigs, which were lying sunning themselves at the base of the cliff. They escaped up through the woods and over the ridge, my hurried shot failing to find a mark. Having reached the top of the ridge ourselves after a hard climb, we were just in time to see the sounder enter a dense patch of thornscrub away down in the valley. Sending the two natives to drive them out, I hurried down the ravine and took up a convenient position below the patch of thorn-scrub. Suddenly the whole sounder broke cover, and to my horror came thundering down upon me like a troop of cavalry. Luckily the pigs were bent more on escape than attack, so when I clubbed my rifle and swung it to beat off, if possible, the mad rush of the fore- 


\section{SINO-MONGOLIAN FRON'TIER}

most pig, he swerved to one side. The others followed suit, but before the last one had passed I managed to reverse my rifle once more, and, firing from the hip, hit him in the jaw. The wounded animal broke away from the rest of the sounder, and, trying to cross a deep water-course, fell an easy mark to my second shot.

Besides the pigs we secured some roedeer and eared pheasants, this being the first occasion on which I had actually seen the latter, though I had often heard them without knowing what they were.

Two of the roedeer were bagged on the last day of the year, while I was out hunting for something with which to furnish our New Year's dinner.

Accompanied by my trapper, who carried my shot-gun, I was making my way up a broad ravine the sides of which were heavily timbered. There was a large open space near the head of the ravine, and a woodman's path led up through the woods to this spot, enabling us to get quietly through the woods to the edge of the glade. Some five hundred yards up the slope were three fine bucks quietly grazing. Leaving the trapper in the shelter of the woods, I dropped upon my hands and knees and wormed my way over the ground. Taking care not to break any dry twigs or to disturb any leaves, I made my way slowly up towards the unsuspecting deer. By making the best use of a slight dip in the ground and a few 


\section{SPORT AND SCIENCE ON THE}

small trees, I succeeded in gaining a point within a hundred and fifty yards of my quarry. Luck was with me, for I was able to rise to my feet behind a small pine without being observed. The distance was nicely judged, and my first shot caused one of the bucks to spring into the air, make a few convulsive bounds towards the shelter of the woods, and then stagger and come rolling down the slope, almost to my feet. The other two deer reached the cover of the woods, where they stood watching their wounded companion. I hurried up the slope and entered the wood where they had vanished. Scarcely had I gone ten paces, before I saw them bounding through the trees, and taking a rapid aim, was fortunate enough to bring one down. 'They were two nice bucks, weighing $60 \mathrm{lb}$. and $65 \mathrm{lb}$. respectively.

The eared pheasants (Crossoptilon manchuricum) gave us a new kind of sport. It was on Christmas Day that we first encountered them. We were sauntering up a wooded ravine when we suddenly caught sight of them running up the steep, wooded slopes. As they were out of shot-gun range I tried a revolver shot at one. At the first report there was a great beating of wings and every bird left the cover of the pines and commenced to sail gracefully across and down the ravine. Needless to say, several passed within easy range of us and were bowled over. The frightened birds would light at the bottom of the ravine and 


\section{SINO-MONGOLIAN FRONTIER}

at once scurry up the opposite side, when a report from one of our guns would startle them into repeating the silly manœuvre, which had already proved fatal to several of their number. In this way we made the very respectable bag of six large birds, averaging 5 lbs. apiece. On four different occasions I encountered flocks of these birds, all of which acted in the same way.

Leopards were numerous in the districts, but I never succeeded in actually encountering one. We tried trapping for these dangerous but handsome pests, without success. They could be enticed to the traps, but always managed to avoid being caught. A live sheep was cleverly extracted from the midst of several traps, which were subsequently overturned and sprung as if to express the contempt of the great feline marauder. Tracks in the ploughed field showed how he had walked round and round the group of traps, planning a way to reach the bait without getting caught.

While up hunting in the highest parts of the range, I came across tiger tracks in the snow. The Chinese in the district said that there were tigers, but refused absolutely to lead me to their haunts, so greatly did they fear this animal.

Several wolves were seen, and one was shot, but it escaped into a wood, where it was subsequently picked up by a shepherd. This was one of a pack of six, which, late one afternoon, after 


\section{SPORT AND SCIENCE ON THE}

I had returned from a long and tiring hunt, passed within a few yards of the house in which we were quartered. I hurried out in my slippers and fired at the last wolf as it crossed a low ridge. Thinking that I had missed him, I returned to camp. That night the five remaining wolves attacked a sheepfold further up the valley, killing eight sheep.

My traps were fairly successful, some seven species of rodents being secured.

The heavy timber in this district consists chiefly of spruce and larch, with a sprinkling of pines. 'The forests are even more extensive than those of the Chiao-ch'êng Shan further south, which were explored on the Clark Expedition. Owing to greater facilities in transporting the logs, this district is being more rapidly deforested.

Besides the conifers already mentioned, extensive patches of scrub-oak, hazel and birch exist, the last being a free peeling variety, from the bark of which the natives manufacture household utensils and mats.

It being winter, we were unable to gather much idea of the rest of the flora of this district, but on a subsequent visit in the autumn of 1911 I was able to observe much more in this line. I then discovered many interesting wild berries, which are dealt with in the botanical notes at the end of this volume.

The mountains here are very high and are mainly of archaic formations. The highest peak, 


\section{SINO-MONGOLIAN FRONTIER}

the altitude of which I estimated by means of boiling point, aneroid barometer, and Abney level, to be some $\mathbf{1 0 , 0 0 0}$ feet, is a stupendous mass of granite known as Lo-yah Shan.

The inhabitants of the district we found to be of the usual type of Shansi mountaineers. Those who had not recently migrated thither from other parts of the province were tall and well built, with healthy, rosy complexions.

The chief occupation of these mountaineers is the cutting and hauling of timber. This is stacked on the banks of the Fên Ho, awaiting the spring and autumn freshets, when it is taken down in long rafts and sold at various places on the T'ai-yüan Fu plain. A vast amount of timber is thus taken out annually, while nothing is being done to replenish the denuded areas.

On January 12 (1910) we once more took to the road, and returning to the Fên Ho, followed it up to its source. A few fruitless days were spent en route at Tung-tsai, a large village engaged in the timber trade, situated about ten miles from the head waters of the river.

On January 17 we discovered a series of mountain lakes, which constitute one of the sources of the Fên Ho. These interesting lakes, which I have already described in my geological notes in Through Shên-Kan, are five in number, the largest being known as Mu Hai-tzŭ, and the second as Kung Hai-tzŭ. These names mean 


\section{SPORT AND SCIENCE ON THE}

the Female Sea and the Male Sea respectively. The lakes are situated at an altitude of from 7,000 to 7,500 feet, and lie in deep rock basins. There are many legends connected with them. One of these states that Mu Hai-tzŭ occupies the site of an ancient town, and it is said that on clear days in summer the ruins can be seen at the bottom of the lake. At the time of our visit the lakes were frozen over to a depth of several feet. The ice, however, was very clear, and near the edges weeds could easily be discerned in the dark green depths.

January 18 found us at Ning-wu Fu, which town has already been described in the foregoing chapter. We made a short stay here to check up and plot the compass traverse.

On January 24 we left this city, and crossing a pass to the west descended on to an extensive plain, which stretches away, unbroken by any hills, as far as the Yellow River.

Traversing this plain for about twenty miles, we reached a small town named Wu-tsai Hsien, where we settled down once more to continue our collecting work.

This time we were very successful, for besides trapping, we induced the natives to bring in specimens. To the number of different species already collected, eight others were added, including the wolf, the fox, the polecat, the mole, a vole, the desert hamster, the striped hamster, and 


\section{SINO-MONGOLIAN FRONTIER}

a new sub-species of hare, which was subsequently named Lepus swinhoei sowerbya, after my wife.

There was no lack of sport, either, in this district, for large flocks of bustards were continually seen, and many fine birds were bagged. Three of these averaged 18 lbs. in weight apiece. As they were very shy, we had to resort to various expedients to come within range. One method was to ride round a flock, gradually drawing nearer. When within range, I would drop off my pony and lie flat, while my wife would gradually edge away, leading my pony and keeping at an even pace. In this way I would be able to take a comfortable shot without startling the birds, whose attention would be centred upon the ponies.

The method we enjoyed most, however, was plain stalking, when by keeping flat upon the ground and utilizing every little ridge or hummock of earth, we could often crawl to within easy range.

One day, to my own surprise and the delight of my wife and the natives, I brought down a large bird, which was flying past me at about seventy yards range. My bullet took it fairly in the side, and the great bird slowly came to earth, a quarter of a mile away. It was stone dead when we picked it up.

Foxes and hares also were plentiful on the plain, but as I seldom went out with anything but my rifle, these escaped attention. 


\section{SPORT AND SCIENCE ON THE}

The Wu-tsai plain is in parts very fertile, but, generally speaking, lacks a good water supply. The district is not notable for anything.

Not more than a couple of miles to the south of the town the plain comes to an abrupt end, and the foothills of the great mountain range we had already visited commence.

By February 15 we had completed our work on the plain, and decided to return to T'ai-yüan $\mathrm{Fu}$. Accordingly we left Wu-tsai and struck out due south, and, entering the mountains, followed a deep valley as far as Tien-p'ing, a small mountain village.

The mountain path which we followed was, in places, extremely dangerous, so that we experienced great difficulty in getting the heavily laden mules along in safety. Often a mere parapet, made of saw-logs and supported by stakes driven into the rock surface, formed the only means of negotiating the steep-sided gorges. More than once the mules, edging up too close to the side, sent their burdens crashing down into the rocky ravine bottoms below, causing considerable damage to our equipment.

At Tien-p'ing the heavily forested mountains looked so favourable, that we decided to stay a day or two to hunt. It was well that we did so, for specimens of a rare flying squirrel were secured. It has not yet been definitely ascertained to what species this squirrel belongs. Having secured four 


\section{SINO-MONGOLIAN FRONTIER}

specimens, I offered the natives 400 cash (about 1s.) for each additional specimen they could secure for me. They discovered a nest of the coveted animals in a hollow tree, when, rather than risk losing one, they plugged up the hole, cut down the tree and carried it bodily to the village over a distance of about three miles. Six squirrels were found inside, five of which I skinned, reserving one alive. This one lived till well into the summer, when doubtless the heat of the plains was too much for it.

During the few days we spent in this vicinity I hunted the sika deer assiduously. This is a beautiful spotted animal about the size of the British red deer. Though I followed their tracks for miles each day, I never succeeded in sighting one, owing to the denseness of the forests in which they lived.

Judging from tracks I saw in the snow, musk deer also were common, but, being much hunted by the natives, they were very shy and always managed to remain out of sight.

On February 23 we once more started for home. Our path now lay over the most difficult country imaginable. The steep slopes were covered with ice, so that our animals had the greatest difficulty in ascending them. Spills were frequent, and more than once the loads were thrown off and boxes smashed.

As we neared the pass, we entered a deep 


\section{SPORT AND SCIENCE ON THE}

forest of very heavy timber, through which we travelled for upwards of two hours. Here the snow was above our knees, while in long chains over its surface were innumerable tracks of deer, wolves, leopards, pigs, foxes, cats, martins and minks. Unfortunately we could not camp in this district, the weather being much too cold, even had we had our tents with us.

The divide, which was marked by a small shrine, I estimated at 8,000 feet. To our left the massive height of Lo-yah Shan towered above the timber line, while to our right the heavily-wooded slopes rose gently to some bare snow-clad uplands. Below and in front of us lay a frozen tributary of the Fên Ho, beyond which a magnificent panorama of blue hills and purple mountains, jagged peaks and winding valleys, spread itself as far as the eye could reach. Behind us were the rugged forest-clad ridges of the Tien-p'ing district.

Reluctantly we descended the southern side of the divide, for we realized that nowhere in all North China could such scenes as we had just gazed upon be rivalled.

That night we reached Wu-chia-kou once more, and being anxious for a little more shooting, we decided to spend two days here.

Our decision was fortunate, as a pig was bagged each day, bringing our total up to five; while a single specimen of the rarest of all Shansi mammals, the little wood-pika (Ochotona sorella), was secured. 


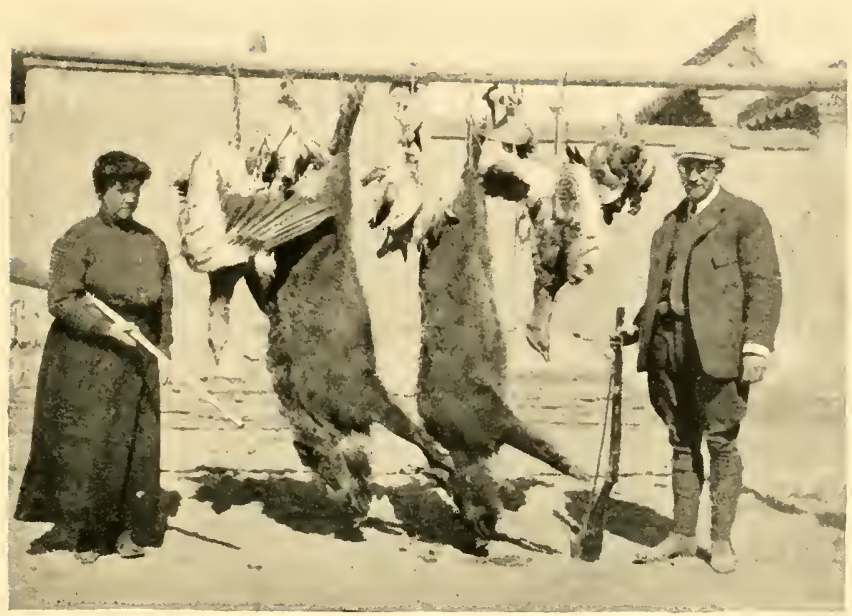

[Photo by K.T. McCoy.

Mr. and Mrs. A. de C. Sowerby with Bag of Wild Pigs, Bustards and Suall Game.

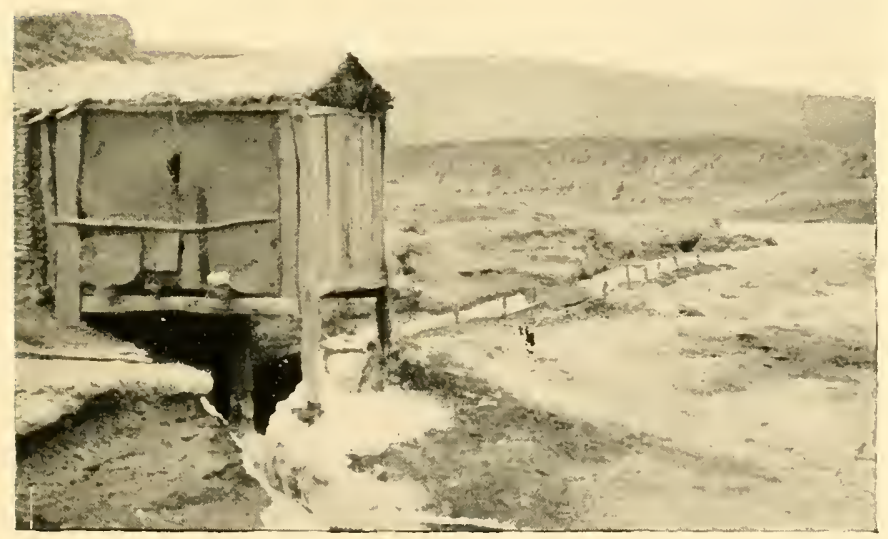

Water-Mill in Winter.

Opposite p. 58.] 



\section{SINO-MONGOLIAN FRONTIER}

With this we were content and continued our homeward journey.

Once more reaching Tsing-lo Hsien, we decided to take a different course from that followed on our outward journey, so turned eastward up a large tributary of the Fên Ho.

Following this up to its source we crossed two high passes in a granite dyke, which here protrudes through the grey limestone. The last day into T'ai-yüan $\mathrm{Fu}$, we travelled for about ten miles along a deep and narrow gorge in the same formation, finally issuing out upon the plain at its northernmost point.

The last fifteen miles were quickly traversed, and we found ourselves home once more after a most enjoyable and successful trip.

We had explored and mapped the greater portion of the upper reaches of the Fên Ho, had discovered some hitherto unknown lakes and extensive forests, and had brought out a good collection of mammals, amongst which one at least was new to science, while six were new to the Institution we represented.

We had enjoyed as good sport as any one could wish for, so that we felt well satisfied with our winter's work.

After our return to T'ai-yüan $\mathrm{Fu}$, our work was discontinued for over a year while we paid a visit to Europe. 

SPORT ROUND T'AI-YÜAN FU 



\section{CHAPTER III \\ SPORT ROUND T'AI-YUAN FU}

$\mathrm{N}$ the summer of 1911 we returned to China, I with the idea of carrying out extensive explorations in Mongolia and Manchuria.

We reached 'T'ai-yüan Fu in July, when, the rainy season being at its height, it was impossible to start our contemplated journey for some time.

I tried one short trip into the mountains of the Ning-wu district, but it ended in disaster, my head servant being accidentally shot by one of his companions.

Subsequently disquieting rumours anent the impending outbreak began to circulate, so that I decided to wait a while to see how things were going, before starting on a long journey northwards.

In view of the general unrest in the country, we had decided that my wife should not accompany me on this journey, but I soon found a pleasant and able companion and assistant in Mr. F. W. Warrington, son of Professor A. W. Warrington of the Shansi University. 


\section{SPORT AND SCIENCE ON THE}

For the time being we contented ourselves with short excursions round the city and into the adjoining country, and were very successful.

September, in China the best month of the year, arrived, and with it the thought of the pheasants and other game, only waiting for the sportsman's gun. We decided therefore to try our luck in the mountains west of T'ai-yüan $\mathrm{Fu}$.

Elsewhere I have described hunting in this particular bit of country, but as I have not done so in the present volume, and as our experiences were typical of what a hunter in these parts usually goes through, a brief description will perhaps not tire the reader.

Hiring mules to carry our stores, and accompanied by one of the railway officials, a Frenchman and a very good fellow, we left the city in high spirits. It was just the right sort of day for travel, and our ponies, fresh from a good summer's rest, curvetted and careered in their anxiety for a gallop across the flats.

After seeing our mules across the swollen river in safety, and traversing the low-lying loess terraces on the western side of the valley, we entered a deep gorge in the limestone formation. Being well mounted, we had long since outstripped the mules, so when we found a clear stream a couple of miles up the gorge we dismounted to have lunch and await the slow-moving train.

We finished our lunch and then put in time 


\section{SINO-MONGOLIAN FRONTIER}

searching for fossils. The hours slipped by, but brought no sign of the mules, so that we began to wonder what had become of them. Finally we rode back to the nearest village, some three miles along the road, and made inquiries of the natives. No, the mules had not passed through the village: no one had seen them. This was awkward. What had become of those mules, or where to go in search of them, we were entirely at a loss to know. We did not want to return to T'aiyüan and spoil our trip, and yet to go on into the mountains without any prospect of food or shelter did not commend itself as a much better alternative. Finally, by much questioning, we learned that there was another path up to the spot where we wished to camp. Putting everything on one cast of the dice, we decided to make for our original goal on the chance that our outfit and servants had already arrived there by this other path.

As night was fast coming on, we borrowed a lantern and set out to make the twelve miles of mountain path as fast as possible. Daylight lasted another half-hour or so, allowing us to get well into the gorge. Our plucky little ponies kept up a sharp trot, even in the darkness, till we reached the end of the boulder-strewn gorge. We then began a steep and, under the circumstances, somewhat dangerous ascent. For upwards of two hours we climbed, sometimes zig- 


\section{SPORT AND SCIENCE ON THE}

zagging up the steep face of a mountain, at other times winding along the edge of a precipice. Once we missed the path and found ourselves at the end of a narrow ledge, looking down into the inky depths of a yawning chasm. Carefully retracing our steps we regained the path, which, owing to numerous landslides, caused by recent rains, was obliterated in many places for yards at a stretch. It was with the utmost difficulty that our sure-footed ponies picked their way over these masses of jagged rock.

At last, however, we reached the village of Shêng-yeh, and to our great relief found that our mules had arrived in safety, and had put up at a little temple. We soon forgot our trying experiences in anticipation of a good week's sport amongst the pheasants.

We got a camp fire going, and were soon comfortably enjoying a good dinner, followed by a smoke, a chat and bed.

Early the next morning we were astir, and after a hasty breakfast we set out over the brush-covered hills. It was not long before we began to flush pheasants, and had excellent shooting. As we traversed the ridges and intervening ravines, bouquet after bouquet of fine young birds, led by magnificent old cocks, rose in front of us, and our guns rang out incessantly. Now and then a hare, breaking cover, would form a little diversion; while once or twice great excitement reigned as a 


\section{SINO-MONGOLIAN FRONTIER}

fat woodcock burst out of some thick coppice of young pines and went rocketing away, sometimes falling to one or other of the guns.

Presently, as we worked down a long ridge, the unearthly and awe-inspiring cry of the eared pheasant (Crossoptilon manchuricum) rang out from a clump of pines on the opposite slope, to be taken up and thrown back from several other points in the underbrush. To my companions the peculiar noise was new, but to me it was a familiar sound, though I was surprised to hear it in this locality.

How well I remember my first experience of that fearsome call, or rather series of calls. I was at the time away in the high mountains of Western Shansi, and was stalking a deer through a dense forest, when the noise rang out within a few yards of me, echoing through the dark arches of the pines and sending cold shivers down my back. I did not then discover the perpetrator of the discordant cries. Later when I was out in Kansu, and was traversing some dark and wooded gorges high up in the Lu-p'an mountains, I was again startled by the same indescribable sound, which seemed to issue from the throat of some fearsome beast of prey lurking in the gloomy depths of those mountain gorges. It was not till the winter of 1909, while on the expedition dealt with in the foregoing chapter, that I discovered it was the eared-pheasant's challenge which had so startled 


\section{SPORT AND SCIENCE ON THE}

me. Thus the sound which now caused my companions to look round in something approaching trepidation, was to me the sweetest of music, as I remembered the fine sport I had already had with these birds.

We hurried round the top of the ridge, and having arrived at a point above the spinny whence the calls had issued, we worked slowly down through the young pines. We had not gone far when three fine birds broke cover and went gliding across the valley. The trees prevented anybody shooting, but we carefully noted where the birds settled. One lighted in a pine tree near the bottom of the ravine, while the other two settled higher up the slope, and in their usual manner began to run upwards at top speed. Hurrying down we approached the tree in which the bird had settled, but nothing could be seen of it. Suddenly it broke cover once more and I managed to get in a shot that made the feathers fly. The bird continued, however, and reached the opposite slope. Again we hurried across to the spot where it stopped, but could find no trace of it. Jimmy, our pointer, soon picked up the warm scent, however, and there ensued a long and exciting chase through the underbrush. None of us could see the quarry, which was running with wonderful speed through the dense hazel-scrub. At last Jimmy caught it and held it till we came up. It turned out to be a magnificent cock, which must have weighed 


\section{SINO-MONGOLIAN FRONTIER}

six or seven pounds. The other two made good their escape.

It was indeed a surprise to me to find this bird, which usually inhabits the highest and wildest regions of the country in such close proximity to the thickly populated country round T'ai-yüan Fu.

On our way back to camp a few more common pheasants were bagged. With this we were satisfied for the time being, and decided to devote the next day or two to hunting pigs.

Accordingly on the following day we shouldered our rifles, and set off towards country, where previous experience had taught me we might reasonably expect to find pigs.

We soon came upon fresh trails, and choosing one, we followed it for many miles through the most picturesque country. At first the trail led along the bottom of a deep ravine, down which flowed a gurgling brook, and the sides of which, stratified and steep, presented a veritable fairyland of ferny grottoes and spongy mossbanks, half hidden by twining creepers, hanging in enchanting festoons. Soon our way was barred by a sill of rock, harder than the rest, over which fell a sparkling cascade of crystal water. Still following the path marked by the deep spore of our quarry, we climbed up the slippery slopes, to be drenched by showers of dew from the autumntinted leaves, which soon would go to increase the richness of the soft mould under our feet. Scram- 


\section{SPORT AND SCIENCE ON THE}

bling upward through rending thorn-scrub, close matted bryony and fast searing hazel, we next came out upon terraces of long, waving grass, which in turn gave place to gentle shale slopes, dotted over with sapling pines and dense bushes, on which the golden berries hung in rich and tempting clusters. Through all this the spore we followed was plain, but presently, as it emerged upon the rocky bluffs of sandstone, it became more difficult to follow, till it was lost in an extensive patch of hazel-scrub, through which only a pig could force its way, and where, in all probability, our quarry was lying up for the day.

Thus we spent two fruitless but interesting days-interesting because of the wonders of nature presented at every step.

Here, in loose coils, lies a viper, his lithe form flattened to catch the full benefit of the sun's rays, while an ugly swelling in the region of his stomach shows that he has recently dined. On an overhead bough is perched an angry chipmunk, screaming at the cold-eyed monster, thus giving vent to his feelings for the loss of his luckless mate. There, in a damp hollow, sits a great toad, his fat sides and throat throbbing and his golden eye ever watchful for some hovering fly or careless, crawling beetle. Soon there passes through the woods a troop of lively, chattering tomtits, each tiny bird examining the under surfaces of the leaves, searching amongst the scales of the pine-cones, 


\section{SINO-MONGOLIAN FRONTIER}

prying into every crack and cranny of the bark, or exploring the hollows under the gnarled and twisted roots, in its everlasting hunt for ants, spiders and grubs. Swish! Down from the blue vault of heaven swoops a fierce hawk. There is a flutter, a tiny cry of distress, and away goes the cruel marauder, bearing in his talons the mangled and lifeless form of one of the lively little tits. The others, momentarily awed by the tragedy, vanish from sight. Presently, as the exuberant and irrepressible energy of each tiny songster once more predominates, first one, and then another, makes a quick dart through the bushes, till the whole troop is once more flitting from tree to tree and bush to bush, chirping and singing as though nothing had happened. Next, the angry scolding of a pair of magpies announces to all the world that they can see a fox sneaking through the scrub upon a covey of unsuspecting partridges. Poor Reynard! his crafty designs thus revealed to his quarry, who hasten to place themselves out of danger, and fearing that he may bring the hunters down upon himself, he creeps away to his lair, there to nurse his hate against those spoil-sports, who, if the truth were known, are guilty of crimes every whit as bad as his own.

Absorbing though all this might be, it was somewhat disheartening not to sight a pig. It became evident that the valleys we were working afforded too much cover for them, so we 


\section{SPORT AND SCIENCE ON THE}

decided to try the slopes on the other side of the ridge.

Once more, as rosy-fingered dawn drew aside the purple veil of night, we shouldered our rifles and made for the sparsely wooded slopes, where we had discovered the eared pheasants. Before long we came upon the fresh tracks of two goodsized pigs. We followed these up all the morning without sighting anything larger than hares, pheasants and woodcocks, though there were not wanting signs that the pigs were but a little distance ahead. At noon we rested in a beautiful ravine, where we made a hearty meal of cold pheasant and bannock, washed down with long draughts of water from the cool stream which gurgled at our feet.

The best part of the afternoon was behind us when signs in the trail, which we had taken up again after lunch, convinced me that we were close up to the pigs. Warrington and I were down at the bottom of a ravine, while our French friend was sauntering along the top of the ridge, looking very bored with the proceedings, and audibly wishing that we would confine our attentions to easier game. Suddenly his voice, choking with suppressed excitement, rang out. "Peeg! Peeg!" Looking up we saw our companion, his face ablaze, beckoning to us with one hand and pointing to a magnificent boar with his gun held in the other. His weapon was a treble-barrelled 

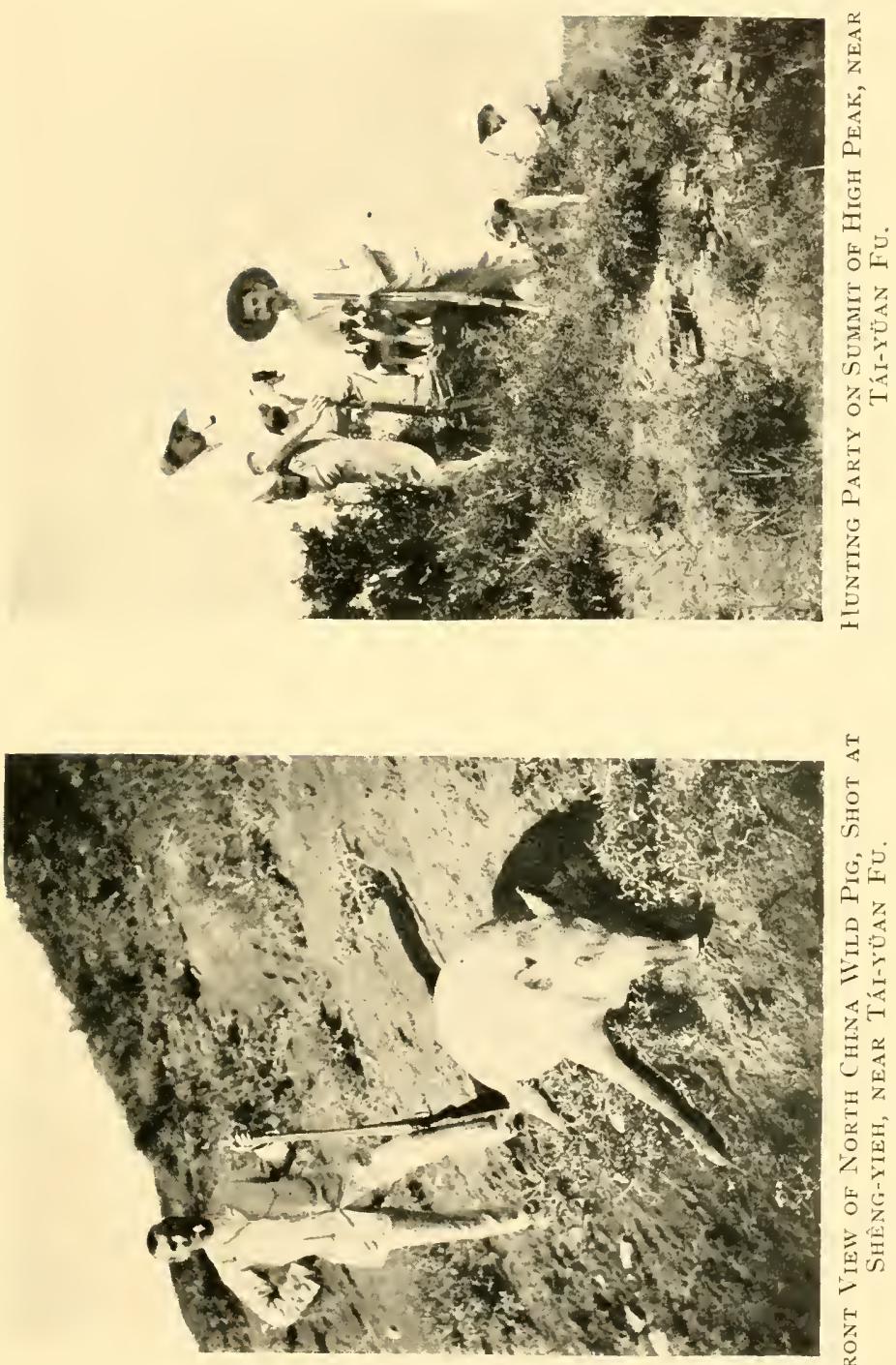

 



\section{SINO-MONGOLIAN FRONTIER}

shot-gun and rifle combined. As soon as he was sure we had seen the pig, he turned and let drive at him with both barrels of bird shot, following this up with the rifle. At the same moment our own pieces rang out, but the pig, stung into madness, tore up the hill and across the ridge. Down the other side he went, regardless of every impediment, leaving a trail of scattered rocks and uprooted bushes. He had gained the bottom of the ravine and was well up the opposite slope before we reached the top of ours. Here in a dense pine spinney we lost sight of him and were too exhausted to trail him further, so he escaped with a dose of No. 4 shot in his hind quarters.

Our time, regulated by the duration of our friend's leave, was almost at an end, so we decided to finish up with a grand drive, in which we hoped to settle the vexed question as to who should claim the honours of the chase.

Unfortunately for me, it proved to be my off day, so that but for a nice right and left at the commencement of the drive, and a bird here and there throughout the day, I missed everything. Warrington on the other hand did particularly well, and the Frenchman increased his total bag by several brace of pheasants. The result of the day's shooting was a win for Warrington. This finished our little trip, and we returned without adventure to T'ai-yüan $\mathrm{Fu}$.

We found that the Revolution had just broken 


\section{SPORT AND SCIENCE ON THE}

out in Hankow, and that the general unrest and excitement was increasing. Being loth to risk my outfit, and knowing that if the North joined in the rebellion against the Manchu power, it would be impossible to travel with any safety, I decided further to postpone our intended journey into Mongolia, spending the time instead in a short camping trip down the river.

Thus it was that on October 12 we found ourselves comfortably settled under canvas upon the bank of the Fên River, about five miles south of T'ai-yüan Fu.

Round us the farmers were busy harvesting rich crops of beans and sorghum. The weather was superb, with just sufficient nip in it to make a stove at night pleasant, and to send the blood coursing through one's veins as one tramped along in the early mornings, watching the sky for the long lines of migrating geese, or beating the scrub and underbrush for hares and quails.

All night long we had heard the honking of wild geese as they passed southward, fleeing from the northern cold, which was steadily advancing to lay its grip upon the land, and now as the grey dawn spread its light over field and flood, we crept out towards one of the numerous dykes which intersect these flatlands, and crouched behind it in hopes that the oncoming geese, flying low as is their wont when there is frost in the air, would afford us a few shots. 


\section{SINO-MONGOLIAN FRON'TIER}

We were not disappointed, for presently the familiar cry was heard, and barely above the horizon we could see a long $V$-shaped line, which steadily drew nearer. Then we saw another, and another, till it seemed as though from the north advanced a conquering army, the many battalions of which were bearing down upon us. On they came, till the first row was almost within range of our guns, when, suddenly, at a warning cry from the leader, who formed the apex of the $\mathrm{V}$, and had evidently caught sight of something that raised his suspicions, the whole flock rose high into the air, passing safely over us.

The next line delayed this manœuvre till too late. As our guns rang out, two birds dropped back from the advancing line. One came hurtling down and struck the bank like a cannon ball; the other, struggling desperately to keep its balance, swerved to the left, and with a mighty rush plunged into the swirling waters behind us, where presently it could be seen floating rapidly down stream. It reached some mudbanks in the centre, and leaving the water lay down to rest. It did not take long to secure this bird, though a wetting was naturally the price.

After this incident, no more geese appeared, so setting up my little accordion boat, we crossed the river to where some thick grass spread over a large area of ground. This we beat through and were rewarded with a couple of hares and a brace or two of quail. 


\section{SPORT AND SCIENCE ON THE}

That evening we set out a line of traps, which we visited thereafter at dusk and dawn, and from which we drew a supply of specimens, including gerbils (Meriones psammophilus), hamsters (Cricetulus triton incanus and $C$. andersoni), and other rodents. We skinned these in the mornings, while we spent the afternoons making excursions down the river or hunting for game. We soon located some bustards, but as yet they were too shy to allow of our near approach, having just run the gauntlet of feather hunters from Mongolia southward.

These birds we hunted with rifles and on horseback, and at length managed to get a flock close up to an irrigation canal. Stalking along this, we came within a hundred yards of the bustards, then cautiously peeping over the bank, each of us selected his bird and at a whispered signal fired. Warrington's bird dropped dead, but mine escaped, leaving behind a few feathers shaved off its back by the bullet.

We discovered some badger holes and set traps for them, but succeeded only in catching a mink, which however escaped, leaving a claw behind in token of its carelessness.

As the days grew colder, more birds came down from the north, and soon we noted large flocks of mallard and teal out on the muddy stretches.

We organized several shooting parties, made up of friends from the T'ai-yüan community, and 


\section{SINO-MONGOLIAN FRON'TIER}

so would ride long distances over the plain, taking everything as it came. In this way we secured many good bags of ducks, geese and hare. Once as we were returning to camp a bustard, flying overhead, was brought down by Warrington, who let drive from horseback with No. 2 shot.

On more than one occasion during these excursions, Warrington, who as yet was not familiar with the treacherous mud-flats, nearly came to grief in the quicksands.

One day, having been tempted out upon the mud-flats by a large flock of water-fowl, we succeeded in securing a goose and two mallards. I went after the former, and my companion after the latter. After securing my goose, I turned to see where Warrington was, and was horrified to see him struggling almost up to his waist in sinking sands. Hurrying to his rescue, I arrived just as he had succeeded in extricating himself. $\mathrm{He}$ had lost his gun, however, the butt of which could be seen protruding just above the surface of the mud. I went to try to secure it, but soon found myself in difficulties, from which I had considerable trouble in extricating myself. We then went inland and cut some sorghum stalks, with which to make a safe path over the quicksands. Some Chinese helped us carry these down to the river's edge. One of them asked me what we were trying to do, as I carefully laid the sorghum stalks out over the treacherous surface. I pointed to 


\section{SPORT AND SCIENCE ON THE}

the gunstock, and told him I wanted to recover it, whereupon he walked into the quicksands, secured the gun and returned without the least apparent effort. He explained the ease with which he managed to do what we had found impossible by the fact that his legs were bare, whereas we had boots and putties on.

On another occasion the pony which Warrington was riding bogged down in a place that looked perfectly safe. The poor animal's desperate struggles only caused the sandy mud to engulf him further. But for the timely assistance of some natives engaged in building a temporary trestle bridge, who came running to our aid with ropes and poles, the animal would certainly have been lost.

Thus we continued day after day, hunting, riding and trapping. Still the province remained quiet, till at last we began to think that after all we might venture upon our proposed expedition, and we were just finishing up at camp on the river when an urgent letter reached us from T'ai-yüan $\mathrm{Fu}$, advising us to come in at once, as an outbreak was about to occur.

A few days later the Shansi soldiers revolted, and raising the Revolutionary flag, declared in favour of a Republic.

This effectually interrupted our work for many months to come. Advice, which amounted to orders, from the Legations in Peking, resulted in 


\section{SINO-MONGOLIAN FRONTIER}

all Europeans in Shansi taking their wives and children to the coast.

Subsequently news of the murder of some missionaries and children and the rumoured peril of the remaining Europeans in the adjoining province of Shensi, led to the formation of the Shensi Relief Expedition, which was placed under my leadership, and which kept Warrington and myself very busy throughout the winter.

Accounts of the journey to and from Si-an Fu, the capital of Shensi, have appeared elsewhere, so they need take up no space in this book. Suffice it to say, we had an exciting and interesting journey which ended in our safe arrival in Peking in January, 1912. 

TRIP TO HSI-WAN-TZǓ 



\section{CHAPTER IV \\ TRIP TO HSI-WAN-TZU}

N our return from the Shensi Relief Expedition, Warrington and I spent a month in Tientsin, after which, things having apparently settled down, I decided to make a trip to Kalgan, a town situated on the southern border of Inner Mongolia. My object was to discover suitable hunting grounds for our spring and summer work.

Thus on February 17, having spent the night at Peking, I boarded the Peking-Kalgan train, and before long found myself being whirled along at a good speed over the great alluvial plain of North Chihli towards the famous Nan-k'ou pass.

After stopping about half an hour at Nan-k'ou station, where there is an hotel, and where an extra engine is usually added, the train entered a deep and narrow valley. The grade being very heavy, we ascended this valley but slowly.

As usual the engines pushed from behind, and the passengers were able to obtain an excellent view, by standing on the end platform of the 


\section{SPORT AND SCIENCE ON THE}

guard's van. As the train neared the head of the valley we caught glimpses of the towers and battlements of the Great Wall, winding snakelike over the tops of the hills. At Ch'ing-lungch'iao (clear dragon bridge) station, those who wish to view the ancient relic of bygone struggles between the Chinese and Tartars leave the train and climb the steep and rocky slopes to various points of vantage. They will see a fine old wall in an excellent state of preservation, marked at intervals with square towers. If, however, they imagine that what they see represents the whole of the Great Wall as it is to-day, they are greatly mistaken. This is only one of a few sections that are in good repair, doubtless due to its proximity to the capital of the Empire. But a few miles westward from this point the Wall becomes a mere ridge of earth, while the watch towers have fallen into disrepair. These conditions prevail all the way to the end of the Wall in Chinese Turkestan.

From Ch'ing-lung-ch'iao the train continued its upward climb for another four hundred feet, when it passed through a long tunnel, and began to descend on to a wide plain. Crossing the plain, which looked very bleak and barren, we passed Huai-lai Hsien, a small town situated upon a rocky prominence on the south side of the railway. Later we entered a narrow, winding valley, at the mouth of which we noticed some coal mines. The Ta-yang Ho makes passage of a chain of 


\section{SINO-MONGOLIAN FRONTIER}

mountains by this valley. The line follows the northern side, passing a small town named Hsiahhua-yuan. Presently the valley widens out once more into a small plain, on which is situated the important city of Hsuan-hua Fu. Here our train stopped for a few minutes.

After leaving this place the line bends northward, leaving the main valley, and, following the course of a smaller one, finally reaches Kalgan.

We arrived at about seven o'clock, after an eleven hours' journey. Putting up at a Chinese hotel, I went in search of the British American Tobacco Company's headquarters. Here I found my friends G. W. Brodie and F. M. Schröder, whose acquaintance I had recently made in Tientsin, and received a kind invitation to have my meals with them while in Kalgan.

They told me they were expecting two friends from Tientsin, R. K. Douglas and R. G. Buchan, who were on their way up for a shooting trip.

Next morning my friends took me for a ride round Kalgan. The town in some ways is typical of those along the border, though it presents many peculiar features of its own. The name Kalgan by which it is known to Europeans, is the Mongol one, and is never used by Chinese. Instead they call it Chang-chia-k'ou, which means " the mouth, or opening of the Chang family," and signifies that originally the place must have consisted of a few buildings situated at the mouth of the valley, 


\section{SPORT AND SCIENCE ON THE}

and occupied by a family named Chang. A great many Chinese place-names originated after this manner. The actual town, or that part enclosed by a town wall, is very small, but the suburbs are very extensive, spreading over the whole of the valley and reaching right up along the deep and narrow gorge leading up to the Han-nor-pa pass. This last section, which is mainly composed of camel inns and business establishments dealing directly with the Mongols, and which lies outside the Great Wall (northern loop), is known as K'ou-wai (outside the mouth). The next section, which consists of cart inns for Chinese, artisans' workshops and private Chinese houses, is known as Shang-pu (upper town). The lowest section, known as Hsia-pu (lower town), is much the largest and includes the walled town and a large area of godowns, hotels, inns and business establishments, all of which have sprung into existence since the opening of the railway.

It is this new factor that makes Kalgan unique amongst the border towns. On one side of the river, which is spanned by a strong stone bridge, we have a busy centre, presenting many of the features of a treaty port, with corrugated iron sheds, Europeanized shop-fronts, one or two foreign-built bungalows, railway sidings and so on. On the other side we have a centre, just as busy, but typically Oriental. Here are bazaars, where 


\section{SINO-MONGOLIAN FRONTIER}

the crafty Celestial temptingly displays, upon the usual small stalls, a gaudy array of trinkets, cloth, ornaments and toys, for the benefit of the innocent Mongol, whose mount, a soft-eyed camel, stands patiently behind, his great jaws for ever working from side to side as he chews the cud, while his master pits his own simple nature against that of the wily stall-keeper in a futile attempt to drive a bargain. A little further up the valley is a wide, open space, used as a horse and cattle market. Here, when a fair is in progress, occur scenes of unusual interest. The Mongols, who bring down their herds, bivouac in the open, making picturesque little groups. The women accompany their husbands and take equal part in the work of selling off their stock. When sales are brisk one witnesses the wildest scenes, as reckless riders tear up and down, regardless of life and limb, in an effort to show their mounts off to the best advantage. The air is filled with the choking dust of a thousand hoofs, while the noise and din are terrific. All this we saw and more, as we rode up the valley in the warm winter sun, and a very enjoyable day we spent.

The evening train brought Douglas and Buchan, with their outfit of tents and greyhounds. They very kindly asked me to join their party. This I was glad to do, as it would take me into new country, besides offering the chance of some sport.

Carts were hired, and on February 20 we left 


\section{SPORT AND SCIENCE ON THE}

Kalgan. It had been decided that the nearest point where we could hope to get any shooting was Hsi-wan-tzŭ, where, we were told, a certain amount of small timber, growing on the steep mountains, gave shelter to a few roe-deer and some small game. Our road lay up the main valley northward from Kalgan, and soon we were up to our necks in trouble. The whole valley was one mass of ice, accumulated during the winter by the daily overflowing of the permanent stream and the nightly freezing of the surface water. Now, the weather becoming daily more mild, this ice had weakened considerably, so that the wheels of our heavily laden carts went through, while the teams slipped and floundered about in their desperate struggles to disengage the unwieldy vehicles. No sooner was one cart free than the next would fall into the same difficulty. By dint of much exertion, the breaking of ice, and the concentration of horse power upon the cart in difficulties, our carters finally succeeded in getting them across the half-mile or so of ice on to dry ground. So long did this take, however, that we could not accomplish more than fifteen miles the first day, and were obliged to put up at a small village named Hsin-yin-tzŭ, where we obtained comfortable quarters.

The following day we continued up the valley, now running in an easterly direction. We were hampered by more ice in a very rotten condition. 


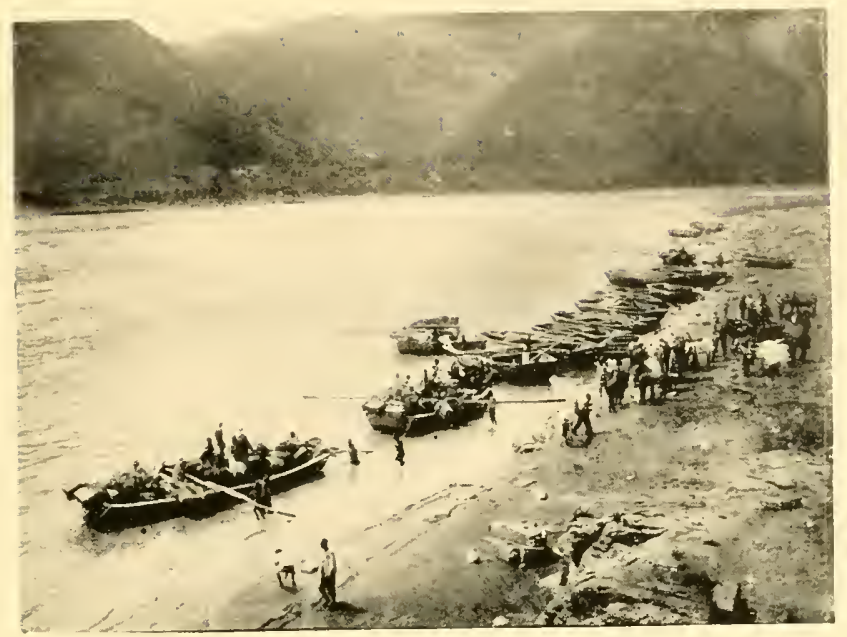

Crossing the Iellow River.

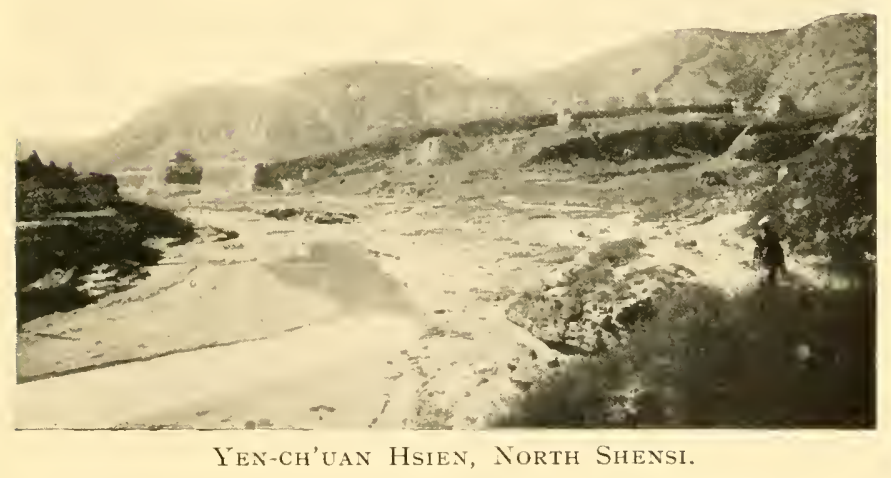

Opposite p. 85.] 



\section{SINO-MONGOLIAN FRONTIER}

Hearing that there was some good pheasant shooting to be had up a valley on the south side of the road, we thought we would try our luck. After a ride of about four miles we reached the head of this side valley and, leaving our ponies at a farm, climbed up towards some scanty scruboak and hazel. Three pheasants and a covey of partridges were the only game flushed. Disappointed and hungry, we returned to our ponies, and after a hearty meal, hurried back to overtake the carts. This we did by riding hard, finally reaching Hsi-wan-tzŭ just as it was getting dark.

That night we put up at a small inn, but next morning, on paying a visit to the Catholic missionaries, received a pressing invitation to stay with them. Father R_, the head of this Mission, very kindly placed three bedrooms, a dining-room and a kitchen at our disposal, and begged us to make ourselves at home. He also told us where we might find game, and appointed two of the natives of the village to act as guides. Needless to say, these hospitable arrangements met with great appreciation on our part. Throughout our stay we were as comfortable as we could have been in our own homes.

We found that we would have to ride five or six miles to reach the hunting grounds, but we scarcely minded this as we were well mounted, It was decided to commence operations at once, so off we rode, following our guides, who were also 


\section{SPORT AND SCIENCE ON THE}

mounted. They led us up a long, winding valley, the slopes of which grew more wooded as we ascended. At last, having arrived at a farm near the head, we left our ponies and began to climb up through the heavy snowdrifts. We saw plenty of deer tracks, but no deer. The snow was very deep, and the uphill climbing was the severest I had ever experienced. In places we had to force our way through waist-deep drifts, getting ourselves soaked to the skin. The first day's hunt proved a failure, but we decided we would change our tactics, and go in for drives, thus saving ourselves the fatigue and discomfort of working through the snow. This method proved far more successful, and it was only the somewhat wild shooting of some of us that prevented our securing a really good bag.

Following is an example of the way in which these drives were carried out. The natives having decided on a likely wood, away up towards the end of a long valley, stationed us in various positions of vantage. I was placed opposite the wood on a sunny slope. Buchan was placed at the mouth of a side ravine near the end of the wood. Douglas and Schröder were placed at intervals further up the same ravine. The beaters then made a long detour, and reaching the other end of the wood, commenced to work through it, shouting and yelling as they came. Suddenly their cries redoubled, and, looking carefully, I 


\section{SINO-MONGOLIAN FRONTIER}

could make out the forms of several deer breaking through the small timber. The herd, which contained five deer, came bounding diagonally down the slope. At the edge of the rood one of them broke back up the hill again, while the other four made straight across the valley towards me. Something turned them, however, and I lost my chance of a good shot, as they disappeared into a side ravine. The lone deer continued along the wooded slope, and I turned my attention to him. He was a little too far for me and going at a great speed in spite of the deep snow. At last he cleared the wood and started up the ravine in which my companions were stationed. He escaped a bullet from Buchan's rifle by a miracle, only to fall at a shot from Douglas. This was our first blood, and we returned to Hsi-wan-tzŭ very pleased with the day's sport.

On another occasion we were similarly placed along a narrow ravine, which skirted a wooded slope. Again a small herd of roedeer were started up by the beaters, and again they ran the gauntlet of our fire. Having successfully evaded Schröder, Buchan and myself, they rounded the shoulder of a hill and ran right into Douglas, who was equal to the occasion and bagged two. One of these was wounded only in the hind leg, and gave the party a long chase through the deep snowdrifts, before he finally succumbed to a long shot from Schröder's rifle. 


\section{SPORT AND SCIENCE ON THE}

In this way four very pleasant though strenuous days were spent. Daily we rode out, first up the main valley, and then up one of the side ravines, to the spot, from which we meant to commence operations. Daily a small band of beaters gathered behind us, as we rode through the scattered villages along our path; and daily we tramped miles through the deep snow or sat impatiently on some sunny slope while the beaters did their work. By noon we were usually in such a ravenous state of hunger, that no matter what kind of luck we were having, we would one and all find our way back to the shack where we had left our ponies, in search of something wherewith to replenish our exhausted vitality. The first man back was expected to prepare food for all. We could usually secure potatoes and eggs, which with the bacon and cold meat brought in our saddle-bags, formed the basis of many a rare culinary masterpiece.

Each night on returning to the Mission, a well cooked dinner awaited us, while usually Father $\mathbf{R}$ _ joined us at coffee time and sat smoking and chatting till late in the evening. The amusing thing about these social evenings was the fact that conversation was carried on in no fewer than five different languages. The Father could speak French, Chinese and a little German and Spanish, but no English, so that Douglas conversed with him in French, Schröder plied his German and Spanish, while I soon fell back on 


\section{SINO-MONGOLIAN FRONTIER}

Chinese, as being the language which came to me most readily.

We learned that all the natives of Hsi-wan-tzŭ were Catholics, as also were many of the natives of the surrounding villages. The magnificent building in which we now rested was built after the Boxer outbreak. The fathers and brothers of the Mission grow their own crops, make their own wine, and brew their own beer. They also own small herds of cattle and sheep, so that the Mission is practically self-supporting. Father $\mathbf{R}$ - gave us some of the wine and we found it excellent, especially some that had lain in their vaults since 1901 .

At last our Tientsin friends announced their intention of returning to civilization, as their time was up. We left Hsi-wan-tzŭ on February 26. The roads were in even worse condition than when we came out, so that it was not till the afternoon of February 28 that we arrived back in Kalgan.

The whole country through which we passed, including that round Hsi-wan-tzŭ, was very rough, and consisted chiefly of igneous and metamorphic formations, though in parts plutonic rocks predominated. These mountains, which form the ragged edge of the Mongolian Plateau, have been deeply eroded. They are bare of vegetation, not because they lack fertility, but because the natives denude them, year by year, of their entire 


\section{SPORT AND SCIENCE ON THE}

herbage. This is due to the absence of coal in the district, which, being transported from long distances, is very expensive. There seemed to be very little room, except along the valley bottoms, for cultivation, but the natives looked prosperous enough.

Leaving Kalgan we returned to Tientsin, and were just in time to witness the looting and burning of the Chinese portion of that treaty port by the native troops and police. The same thing having happened in Pekin but two nights before, things were getting pretty lively once more. The soldiers who had indulged in the looting of these places decamped in hundreds, and scattering through the country made travelling somewhat hazardous. Pao-ting Fu, and other large towns along the Pe-Han Railway, were next cleaned out by disaffected troops, and we were hourly expecting news that the Sixth Division troops stationed at T'ai-yüan Fu had revolted. All my collecting and camping outfit, to say nothing of my surveying instruments, my wife's and my entire wardrobe, and all our household gods, were stored in this town.

As I could not hope to do any useful work in Mongolia without these things, and as they could not be replaced in China, I decided to make an effort to recover them. Thus, accompanied by Warrington and a friend named Donald R. Woods, I proceeded to T'ai-yüan Fu. On 


\section{SINO-MONGOLIAN FRONTIER}

arrival we found all our property exactly as we had left it, and were also successful in recovering a substantial sum of money from the agents of one of the banks destroyed by fire at the outbreak of the Revolution.

The city was in the hands of the Sixth Division troops, who kept the inhabitants in a perpetual state of terror. Although they had received orders to return to Peking, they were demanding the sum of taels 50,000 before they would leave. But for the fact that the city had already been looted, they would certainly have mutinied and fallen on the luckless townsfolk. Finally they were content with a payment of taels 25,000 and left the province quietly.

While in T'ai-yüan $\mathrm{Fu}$ we were fortunate in getting some really good sport in the way of wildfowling. It happens that along the whole of the western wall inside the city there are marshes and ponds, which have always formed good feeding grounds for snipe and wild ducks. Visiting these ponds early one morning, we soon discovered some large flocks of ducks. A shot or two set them flying, when, by crouching behind some mud dykes, we enjoyed for a few minutes some splendid flight shooting, as the disconcerted birds repeatedly flew back and forth over our heads. Our fun, however, was soon stopped, for the guard at the West Gate came hurrying up and begged us to leave off firing. It turned out that 


\section{SPORT AND SCIENCE ON THE}

the rapid discharging of our fowling pieces had alarmed the inhabitants of the suburbs, who, thinking that a fresh outbreak had occurred, came hurrying up armed ready for war. Needless to say, we decided to forego our sport and returned to our quarters.

Next day, however, we took train to a small village named Pei-ho-liu, where we could indulge without fear of interruption. Here a beautiful stream bubbles up from the base of a low sandstone outcrop, and is used to irrigate a large area of rice-fields, where, in the season, snipe are very plentiful. Scarcely had we formed up in line with intervals of thirty or forty yards between each of us, than the snipe commenced to rise, and for several hours the sport was fast and furious. Of course many birds escaped, but plenty were added to the bag, which increased steadily. By lunch time we each had several couple of snipe, so we all repaired to a small shrine at the source of the spring, where we made a hearty meal.

After lunch, as there were still several hours before the return train was due, we set out once more for the paddy fields. The snipe had collected again while we were at lunch, so that we had some more good shooting. The usual rivalry existed and each man anxiously sought out the most likely spots, in the hopes of securing a bird or two more than the others. Some quails were flushed and potted, though a trio of pheasants. 


\section{SINO-MONGOLIAN FRONTIER}

rising on thundering wings from some long grass, managed to elude the scattering of small shot that followed them, as they whirled away towards the hills.

At last we decided that we had had enough, so returned to the station, where we counted our bag. It consisted of twenty-five couple of snipe, three quail and a brace of plovers.

A few days later we had packed all our effects, and, having secured a goods wagon, stowed them away, leaving sufficient space for ourselves. We had decided to travel down by goods train, so as to guard our stuff from any would-be looters. This was an excellent arrangement, for with camp beds, tables and chairs we made ourselves very comfortable, and, by keeping the big doors of the car open, enjoyed an uninterrupted view of the beautiful Shansi scenery, throughout the whole day's journey.

We arrived back in Tientsin without any untoward incident, and, having arranged everything to our satisfaction, left for Kalgan on April 23, on our way to the wild sheep country in the K'uei-hua-ch'êng district of North Shansi. 



\section{JOURNEY TO K'UEI-HUA-CH'ÊNG : THE T'AI HAI}





\section{CHAPTER V}

\section{JOURNEY TO K'UEI-HUA-CH'ENG : THE T'AI HAI}

A RRIVED at Kalgan, we were delayed some 1 days, owing to the usual bother in hiring carts. It happened that Brodie and Schröder had been ordered to proceed to K'uei-hua-ch'êng on business, so we decided to travel together. Carts were finally secured and sent on to Yangkao, the present terminus of the Chang-sui Extension of the Peking-Kalgan Railway.

On April 29 we took train at Kalgan, and, after about six hour's' journey, reached Yang-kao, where we found our carts awaiting us. The Chang-sui Extension line runs in a general southwesterly direction from Kalgan, and is intended ultimately to extend as far as K'uei-hua-ch'êng, and the Yellow River, probably at He-k'ou.

From here it is intended to have a steamboat service to Lan-chou Fu. Already a light-draught, stern-wheel steamer has been built and launched upon this section of the river. If this enterprise succeeds, as it should do, the long journey from 


\section{SPORT AND SCIENCE ON THE}

Peking to Lan-chou Fu will be reduced from thirty odd to seven days. This will open up the vast areas of Western Kansu, the New Dominion and Eastern Thibet to trade with the coast, and the results must be very far reaching. Hitherto the barges which have brought commerce down the river have been unable to return; but, with steamers passing up and down, this difficulty will be solved. Better and stronger barges will be built to be towed to and fro, carrying commerce up as well as down the river. But all this is indefinitely postponed owing to the disturbed state of the country and the lack of funds at the Capital.

Yang-kao, the present terminus of the railway, is about ninety miles from Kalgan, and lies on the edge of the Ta-t'ung Fu plain, just south of the outer loop of the Great Wall, and within the eastern border of Shansi.

The railway, after going south from Kalgan for about four miles, turns abruptly to the west, skirting the end of a ridge of high hills. It next takes a diagonal course across the wide valley of the Ta-yang Ho, which splits up into three rivers, called Tung-yang Ho, Hsi-yang $\mathrm{Ho}$ and Nanyang Ho respectively, just before Tsai-kou-pu, a town thirty miles from Kalgan, is reached. The line crosses the first two of these rivers before reaching the station of Tsai-kou-pu. It subsequently follows the course of the last, which is 


\section{SINO-MONGOLIAN FRONTIER}

narrow and tortuous. It continues winding up this valley, which gradually widens and finally opens out into a small plain adjacent to that of Ta-t'ung $\mathbf{F u}$, from which it is separated only by a very slight rise.

The scenery along the line is picturesque only round Tsai-kou-pu, though the high mountains north of Yang-kao have a rough beauty of their own. Along the base of this range the Great IVall, which has been lost sight of since leaving Kalgan, can be seen running parallel with the railway line. In places the country passed through appeared to be extremely fertile, though there are great stretches of land composed of rubble and rocky debris, brought down from the granite mountains, upon which nothing but a few straggling willows and poplars grow.

As a severe sandstorm was raging when we arrived at Yang-kao, we decided to spend the night there and continue our journey next day. The town itself presented nothing of interest. It was, at the time of our first visit, of the usual type of small border town. A few months later, however, when I had occasion to visit it once more, the change was remarkable. In one summer an extensive trade in grain sprang into existence in the district, and Yang-kao being the centre of this district, and the terminus of the railway, by which the grain was shipped out of the country, assumed for the time being a commercial 


\section{SPORT AND SCIENCE ON THE}

importance superior to any other town in North Shansi. Godowns, inns, hotels and even private houses sprang up like mushrooms round the station, while there poured in from all parts of the northern section of the province strings of carts laden with sorghum, millet and linseed. Large firms in Tientsin, which had never heard of the town before, found it worth their while to send European agents to buy up grain for them. This prosperity did not last, however, for the moment the line was carried on to Ta-t'ung $\mathrm{Fu}$ and towns beyond, a great bulk of the grain shipped at Yang-kao was shipped at these towns instead. The line itself, however, will remain of the greatest importance, as tapping a very extensive agricultural area. A few more such railways, carefully run, would go far towards bringing in a steady revenue to the Chinese Government, besides developing the hitherto poverty-stricken districts along the Chinese frontiers of Mongolia.

The morning of April 30 broke fine and clear, so that we made an early start. Travelling northward, we soon reached the mouth of a deep valley in the mountains, entering which we turned westward up a side gorge. By noon we had reached the end of the latter, and crossing a low, almost imperceptible ridge, marked by the crumbling towers of the Great Wall as it passes from north to south across the road, entered a rather wide 


\section{SINO-MONGOLIAN FRONTIER}

valley. We made a large village named Kuant'ung-pu by dusk, and put up for the night.

Next day, shortly after leaving this village, we climbed a short ascent, and found ourselves upon a low, rolling tableland, which on examination proved to be formed by an extensive lava flow. In places where the rock was bare of soil it presented the appearance of a causeway paved with hexagonal flagstones, indicating columnar structure beneath. We put up several hares, which were bagged. A large flock of cranes was also seen, but they were too wary to allow of a near approach. Further on a goose was shot, but after flying a long way, it dropped upon a boulder-strewn ridge, and could not be found. After about two hours' journey we came to the western edge of the lava flow, from which we looked down upon a wide valley and winding river. The steep and rocky descent was negotiated by means of a zig-zag road without mishap. Some more hares and two partridges were put up and shot. Out on the river bank some large flocks of geese could be seen. In trying to get at these Schröder surprised and shot a bustard, while Warrington and Brodie got some good shots at a flight of ducks.

Travelling up the valley we halted for lunch at Fên-chêng, a large and important town, with the rank of T'ing. After leaving this place we found ourselves on a flat, grassy plain. In places this 


\section{SPORT AND SCIENCE ON THE}

was inclined to be marshy, where amongst the tussocks of "nigger-head" grass, we put up a great many hares, several of which were secured. Two Swinhoe's ducks, rising from a small stream, were knocked over with a nice right and left, while a late snipe was also added to the day's bag, which had now reached the respectable tally of six hares, four ducks, two partridges, one bustard and a snipe. Four of the hares, two ducks, one of the partridges and the snipe fell to my gun; Brodie claimed two hares and a duck; Schröder, who was using a 22 Winchester, the bustard; while to Warrington, who, having a tiresome pony to manage, had left his gun in the cart after lunch, belonged the remaining duck and partridge. We found comfortable quarters that night at a small village named Ma-ch'angling.

Next day the sport was as good as that already enjoyed, though the honours were more evenly divided, the day's bag being four hares, two ducks, two plovers and a goose. It is this abundance of mixed small game which lends the chief charm to travel in the interior of China. One may always expect to find something to shoot. There are districts, of course, where no game is met with at all, but fortunately these are not many, usually occurring along much frequented highways in thickly populated areas.

The country passed through this day was similar I06 


\section{SINO-MONGOLIAN FRONTIER}

to that already traversed. By noon we reached the T'ai Hai (Great Sea), a large lake, which lies in the hollow of a great basin-like plain. To the north lies a chain of high and pointed mountains of granite. Eastward the plain is bounded by low hills of volcanic origin. The same may be said of the southern rim, while the western boundary is formed by a low spur from the high mountains to the north. There is no outlet. The lake is said to be very deep, especially on the eastern side. The water is very brackish. We were told that there were no fish in it, though there seems to be some doubt upon this point. In length the lake is about fifteen miles, and seven or eight in breadth. Its greatest length is from east to west. From the inn, where we had lunch, we could see, with the aid of field-glasses, that the edge of the lake was swarming with wild fowl. Notwithstanding this fact, we found time to demolish the bustard, which the cook had prepared for us the night before. It was a tenpound bird, so the healthy state of our appetites may be guessed.

After lunch, having given directions to the carters where to halt for the night, we hurried down to the lake, expecting to enjoy some good shooting. We were disappointed, however, for at our approach the birds, amongst which were several large swans, rose thundering from the margin, and, skimming over the surface of the lake, settled safely 


\section{SPOR'T AND SCIENCE ON THE}

out of range. Nothing we could do would induce them to rise and circle.

While waiting for the ducks to come within range, we witnessed a peculiar sight. Heavy yellow clouds began to bank up to the north of the lake. Soon we could make out that an unusually severe sandstorm was approaching. The solid looking clouds towered high above the mountains, and as they came on with incredible speed, blotted out the scenery as though some ruthless hand had wiped a picture off the canvas with a sponge. Thinking that this would probably bring the ducks in to shore, we waited. At last the storm, sweeping over the lake and churning the surface into foam, struck us. Suddenly the temperature dropped from that of a sweltering hot day to below $40^{\circ}$ Fahrenheit, chilling us to the bone. At the same time the driving rain, thick with the dust it had absorbed, whipped our faces and literally plastered us with mud. No ducks came to shore, so at last we mounted our ponies in disgust and hurried after the carts. We caught them up at a village named Ma-hu-t'ung, and, as the wind and rain continued with unabated fury, we decided to stop here for the night.

We were skirting the eastern shore of the lake, intending to take a newly opened route through the high mountains to the north of the lake, instead of the usual southerly route.

The two days following were uneventful, ex- 


\section{SINO-MONGOLIAN FRONTIER}

cept that the temperature remained very low, so that we were forced to go back into winter clothes once more. Our road lay along deep mountain valleys, the sides of which were chiefly of granite, very bare and rugged, and we crossed two steep passes. By the end of the second day we had reached the edge of the K'uei-huach'êng plain, crossing which we reached that town at noon next day.

We spent one day looking round the town and lazing about, while a coolie was sent in search of an old Mongol hunter. Our friends of course had their business to attend to, which would keep them in town a few days. K'uei-huach'êng, though in no way like the usual cities of North China, is, nevertheless, a place of great importance and no mean dimensions. It consists of two sections, one Chinese and the other Manchu. The latter, known as Sui-yüan-ch'êng, lies a mile or so to the north-east of the former, is enclosed by a strong wall and is the seat of Government. Here lives a large community of Manchus, numbering some ten thousand, the adult males of which are, or were up till recently, conscript government troops.

The Chinese portion, which is K'uei-hua-ch'êng itself, consists of a small walled town surrounded by extensive suburbs. The population of this section, which, to a large extent, is floating, has been estimated at 40,000, which, however, is 


\section{SPORT AND SCIENCE}

probably excessive. All the commerce and trade is centred in the Chinese quarter. The principal items of commerce are wool, skins, hides, cereals and livestock, besides numerous articles required by the Mongols, which they cannot make themselves. A great portion of the trade between the New Dominion (Chinese Turkestan) and the coast passes through K'uei-hua-ch'êng, as transport by camels along the desert route is very much cheaper than by carts or mules along the high road through Shensi and Kansu, via Si-an Fu and Lan-chou Fu. The camel caravan route keeps north of the Yellow River, and owes its cheapness to the fact that the camels can fend for themselves, not requiring to be fed. Its chief drawback is the length of time required, seventy days being the number usually given in road contracts.

There are some interesting temples at K'ueihua-ch'êng, harbouring large numbers of Lamas. Both the Protestant and Catholic Missions have opened stations here, while there are postal and telegraphic communications with the coast.

Both K'uei-hua-ch'êng and Sui-yüan-ch'êng have the rank of T'ing. 
AFTER ARGALI AND WAPITI 



\section{CHAPTER VI}

\section{AFTER ARGALI AND WAPITI}

$\mathrm{E}_{\text {ARLY next morning, the Mongol hunter }}^{\text {ARing been found, and his services secured, }}$ Warrington and I set out for the mountains. Crossing the five miles of plain, we reached the mouth of a deep valley, where, in a small village, we found our guide waiting for us.

Here we left our ponies, and, crossing the boulder-strewn valley bottom, began a stiff climb, which finally brought us to the top of a high ridge. From this point our view extended over a wide panorama of rugged mountains and deep and precipitous valleys and ravines. These we scanned carefully with field-glasses, but finding nothing, descended into one of the valleys, and began to work up it.

Almost at once we found ourselves in game country, for we had not gone far before we spied a sheep watching us from the crest of a side ridge. He did not seem to mind our presence, so that we were able to get a shot at him. Unfortunately the size of the animal misled us in estimating the 


\section{SPORT AND SCIENCE ON THE}

distance, so that our bullets fell short. With a few bounds he was up the side of the hill and away. Further up the valley three magnificent rams, which had been disturbed by some woodcutters, came bounding down a small ravine, but, catching sight of us, they turned abruptly, and with incredible speed tore diagonally across the steep mountain side. Gaining the valley bottom, they broke away in the direction we had just come, and were soon out of sight round a bend. A shot or two at these also failed to find a mark.

Somewhat discouraged by our poor shooting, we turned up a side ravine, and after a long, gradual ascent, came out upon some grassy uplands. As we skirted the edge of these, the quick eye of the Mongol detected three rams grazing upon a patch of green grass at the bottom of a valley. This was what we wanted, so ducking down to keep out of sight, we crept away from the crest of the ridge, and made a long detour. On our way we put up a herd of six or eight ewes, which scampered off, stopping every now and then to gaze back at us. At last we reached a clump of rocks, which I had marked as being directly above the grazing rams. Cautiously peeping over, I was disappointed to find the latter had gone, but, on looking up, I saw all three grazing on the opposite slope, about four hundred yards away, as I estimated. I beckoned to Warrington to creep up beside me: we both 
PLATE VIII.

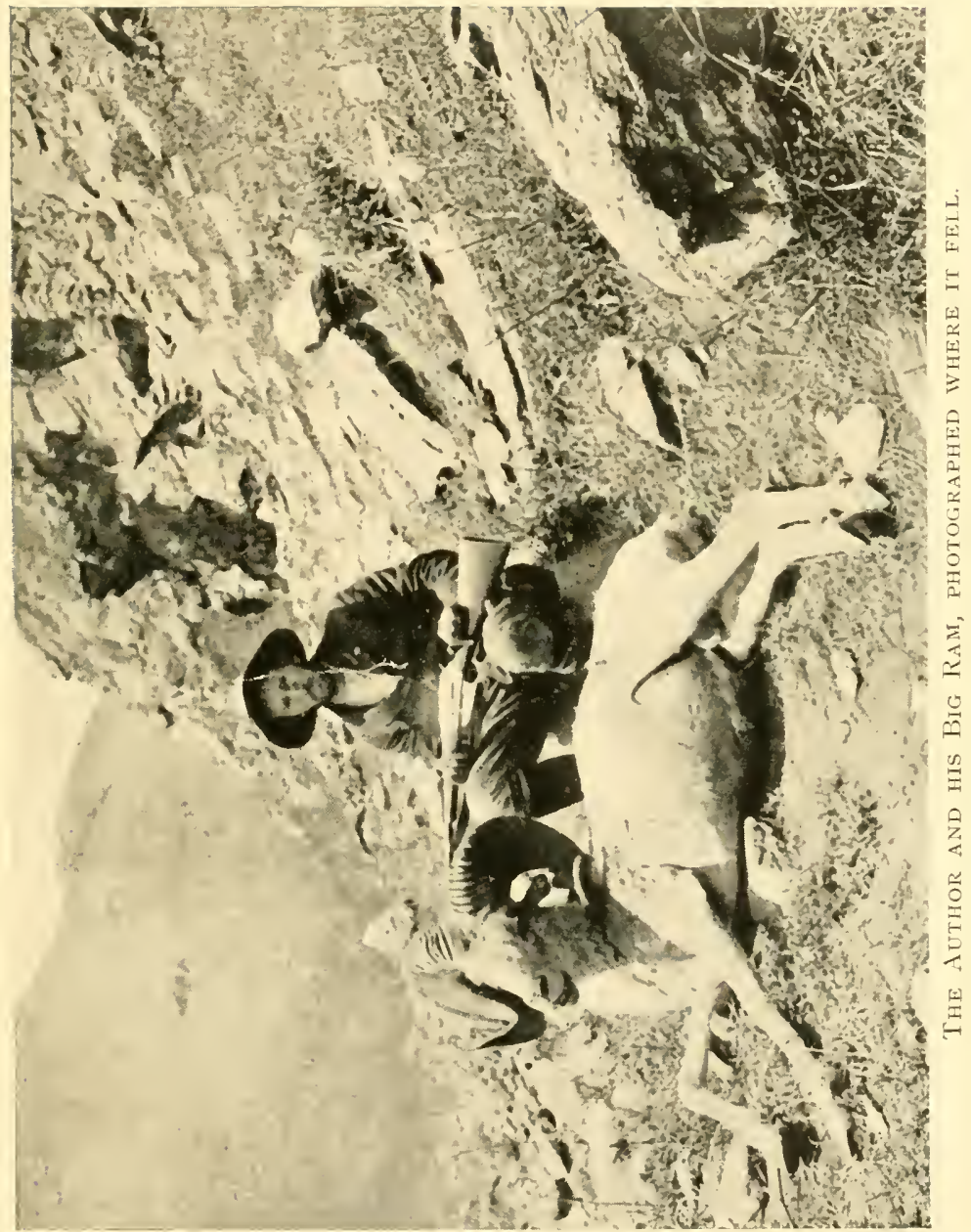





\section{SINO-MONGOLIAN FRONTIER}

took careful aim and fired. To our chagrin the bullets again fell far short of the sheep, which at once made off with long bounds. Again and again we fired, but missed hopelessly every time. They crossed a low ridge into a second ravinc, presently appearing again, slowly climbing a distant slope. Three other rams emerged from the same ravine, and broke westward for the highest ground.

This was indeed disappointing. So clear was the atmosphere that we could see every detail of those rams as they had stood there on the hillside, in spite of the fact that they must have been from six to eight hundred yards distant. Besides, not having seen an argali at close quarters, we did not realize their immense size, and so judged them to be much nearer than they were. Nie saw no more sheep that day, though we both had a shot at a large wolf.

On our way back down the crest of a long ridge we suddenly came upon two roe-deer, both of which I bagged. At last, tired and hungry, but full of enthusiasm, we returned to our quarters in K'ueihua-ch'êng, where we recounted our adventures to our companions.

The heavy day's climbing on top of our long journey so tired us that we did not feel inclined to go after sheep next day, but spent the time overhauling tents and other gear, with a view to making a camp right in the mountains, so 


\section{SPORT AND SCIENCE ON THE}

saving the daily ride from town to the hunting grounds and back.

The following morning saw us once more heading for the mountains, this time with two tents, stores, collecting outfit, beds and bedding, together with other camping requisites, loaded upon five camels. The latter, being unable to climb the first ridge, were obliged to make a considerable detour, and follow up from the plain the course of the valley, in which we intended to camp. We left them to take this route, while we crossed the ridge in order to get in a bit of shooting.

This time, as there were four of us, we split up into two parties, one following up the valley, the other climbing the side and working along the top of the ridge. After having gone about half a mile those on the ridge put up a small herd of sheep, which broke back towards the mouth of the valley. They crossed it about five hundred yards below me. With the sun full in my eyes, I had difficulty in making them out, but let fly with my rifle, apparently doing no damage. Turning to follow them, I arrived at the spot where the herd had crossed the valley, and hunted about to pick up the trail. To my surprise I found a spot of blood. At this moment Schröder appeared at the end of the spur above me, so waving to him to come down, I began following up the tracks of the wounded sheep. 


\section{SINO-MONGOLIAN FRONTIER}

Presently he joined me, and together we spent an hour or more working out the somewhat difficult trail. It led us up a steep and rugged mountain side, across the divide and down the face of a precipice. Sometimes we actually could not climb down the places taken by the wounded sheep at a bound, and were forced to find easier paths. At last the blood in the trail increased. There were several big splotches, showing where the animal had stood to rest, or look back along the trail. Presently, as we rounded a bend, a large ewe sprang up from a sheltered nook, and with only three sound legs began to climb upwards with wonderful agility. Our rifles rang out, and the sheep came rolling down the precipitous slope, fetching up at the bottom of a ravine a hundred feet below us. Naturally, I was greatly disappointed at its being a ewe. Owing to the distance, and the fact that I had the afternoon sun full in my eyes when I fired, I could not make out clearly of what the herd had consisted. However, for my collection this ewe was more valuable than a ram, owing to the females of the genus Ovis showing more plainly the cranial characteristics of the species, so I could not complain. It was more than either Schröder or I could do to carry the sheep, but after gutting it we tied the carcase upon the native hunter's back, who being more accustomed to the heavy gradients, managed to 


\section{SPORT AND SCIENCE ON THE}

pack it to camp. We estimated the weight of the ewe at about $200 \mathrm{lb}$.

By the time we reached the site chosen for camp the tents were up and a delicious cup of tea awaited us. Dinner followed very shortly, and after setting a line of traps for small quadrupeds we turned in.

The following day we continued to hunt, but saw only two old rams all day. Two young sheep (two-year-olds), a ram and an ewe were shot by two of the party. These also came in handy for specimens, though their coats were in very poor condition. I bagged another roe-deer late in the afternoon.

The third day was more propitious, at least for one member of the party, who was fortunate enough to secure a ram with a fine pair of horns. The lucky man was Brodie, who, with Warrington, was working the ridges to the south of our camp, while Schröder and I tried the higher country further west. They had sighted and followed for a considerable distance two old rams, but had at last given up the chase as hopeless, and were sitting on a ridge watching their quarry away across a wide valley. Suddenly the rams turned back and came full speed towards the ridge upon which sat the hunters. There was a small ravine on either side of this ridge. The rams entered the one on the right, and, having arrived opposite the two crouching men, stopped and stared back 


\section{SINO-MONGOLIAN FRONTIER}

along the path they had come. Both sportsmen fired, but the rams crossed the next ridge, seemingly unhurt. Following them up, however, Warrington, being younger, lighter and more agile than his companion, outstripped him, and came upon one of the rams lying in the ravine bottom. He hurried up to the prostrate animal, which suddenly jumped up, and, realizing that he was cornered, lowered his ponderous head and charged. Visions of being crushed between that mass of horn and the solid rock behind him crossed the lad's mind, but he had the sense to fire low at the oncoming and infuriated ram. His bullet struck the brute in the chest and dropped him dead.

We now had one more day to spare, and I had not yet secured my head. I had picked up two skulls with fine pairs of horns, one of which, measuring $19 \frac{1}{2}$ inches in circumference at the base, constitutes a record.

I badly wanted a head for myself, however, and determined that I would get one somehow that day. I was convinced that the grassy upland was the most likely spot for me to get my sheep, so, accompanied by Schröder, I proceeded up the valley from our camp. Brodie and Warrington were also heading for the same district, but by a different route. Arriving upon the grassy heights we sat down to rest and look round. Presently Schröder spotted three rams on an 


\section{SPORT AND SCIENCE ON THE}

adjacent ridge. I got out my glasses and made out that the leader had a fine pair of horns. The rams, which had not seen us, moved slowly over the ridge. After a hurried consultation, it was decided that I should go down the valley, skirt the end of the ridge over which the rams had disappeared, and work up the next ravine or valley. Meanwhile Schröder and the other two, whom we could see approaching over the rolling uplands, would station themselves in suitable positions to intercept the flight of the rams when I had disturbed them. I was soon at the bottom of the valley, and having reached the end of the ridge in question, decided to climb up it, as in this way I could keep more ground in view. At last as I neared the top I came upon a wide ravine, or "draw," shaped like an amphitheatre, and communicating with the main valley by means of a narrow outlet. It was this draw which the three rams must have entered on crossing the ridge. I stopped to get my breath, at the same time carefully scanning the slopes for any signs of the sheep. Not seeing any, I was about to continue up the ridge, when, glancing at the narrow opening, I was surprised to see the three rams come quietly sauntering up a grasscutter's path. There was the leader with the fine pair of horns, followed closely by a young ram, whose horns had only attained a semicircle. The third ram, which in size was not far short of the leader, showed more 


\section{SINO-MONGOLIAN FRON'TIER}

independence and lagged in the rear, nibbling at tufts of grass along the path.

All these details I took in as I slowly raised my rifle. The leader must have caught the sun-flash on my rifle-barrel, for he suddenly looked straight up at me. It was now or never, so keeping the sights low I pressed the trigger. The leader collapsed, kicked once or twice and lay still. I tried a second hurried shot at the third ram, as he turned and dashed out of the ravine, but failed to hit him. Scarcely believing my eyes, I carefully descended towards the ram, keeping a sharp look-out, with my rifle ready in case he should get up and start off, as so often happens with big game. My precautions were unnecessary, however, as he was stone dead. My bullet had taken him in the spine, just above the shoulder, where it had lodged. A hot wave passed down my back as I realized how nearly I had missed him. After taking some photographs, the hunter and Iskinned the ram, which, on measurements being taken, was found to be $45_{4}^{3}$ inches at the shoulder, and $55 \frac{1}{2}$ inches round the chest. The horns at their base had a circumference of $18 \frac{1}{2}$ inches, and were 43 inches in length, having one complete turn. The following day, after a fruitless chase after a couple of gorals, we struck camp and returned to K'uei-hua-ch'êng. My traps yielded nothing whatsoever during our stay in the sheep country, from which it may be inferred that that country is 


\section{SPORT AND SCIENCE ON THE}

very poor in mammals. Indeed, besides the sheep, the roe-deer, a few gorals and the wolf, the only mammals we saw were one or two chipmunks. Birds also were very scarce; eagles, kites, crows, larks and a few partridges and chukars were all we saw. The scarcity of animal life in this district is doubtless due to the corresponding lack of vegetation, there being only very little scrub and no timber, either large or small.

\section{WAPITI}

Our next objective was a point some thirty miles west of the sheep country, where, the natives said, there were plenty of wapiti, and even tigers. Thus, after a day or two spent in K'uei-hua-ch'êng we once more left that town, taking a westerly direction. We had the five camels again, this time augmented by a cart, as we had further to go and were taking more stuff.

We followed the main road for seventy li (about 20 miles), passing many farms and one or two small villages on the way, and finally arrived at Pi-ch'ien-ch'i, a large market village. There we put up for the night in a fairly good inn.

Next day it was raining when we rose, and we were delayed till noon, when we once more set out, this time in a more northerly direction. The poor camels had a terrible time, as they slipped and floundered about in the mud. They cried piteously whenever they came to a bad part, and 


\section{SINO-MONGOLIAN FRONTIER}

it was only with the greatest difficulty that they were induced to proceed at all. Presently we reached the mountains, and entering a deep and winding valley followed it up for about ten miles, when, as darkness was descending, we were obliged to put up for the night at a small village named Wu-lan-pan.

Continuing up the valley the following day, we crossed the divide at its head, and entered a second, much larger valley, up which we travelled as far as a tiny hamlet called Ssŭ-he-tien, where we had lunch. Leaving this place, we entered a deep side ravine, the winding boulder-strewn course of which we followed as far as the cart could go. At this point we stopped and pitched camp.

We were now in the very heart of a region of high, rugged and precipitous mountains, the deep gorges and ravines of which were filled with small timber. This extended up the steep slopes in many places, while away down in the shadowy ravine bottoms sparkling brooks, now only partially ice-bound, gurgled and plashed over the rounded pebbles and polished boulders. Here and there deep pools temptingly invited a plunge, but the little fringe of ice acted as a gentle reminder of the still frigid temperature. In these pools shoals of small fish might be seen darting in and out of the dark caves beneath the overhanging rocks. On the mountain sides the tender green of the sprouting poplars and hazels contrasted strangely 


\section{SPOR'T AND SCIENCE ON THE}

with the deep colour of a few scattered pines, while the mountain peach and wild apricot blossomed pink and white, lending a soft beauty to the landscape. Above all the jagged needle-like peaks of granite towered away into the azure blue of the cloudless sky, like the enchanted castles of our childhood's fairy-tales.

Having arranged camp to our satisfaction, we immediately set out in search of game wherewith to fill our larder, as we had brought no meat with us. We had climbed the opposite slope but halfway, when three roe-deer were put up. Our rifles rang out, but the deer continued bounding through the bushes. One, however, broke away from the others and came towards us. Schröder and I fired simultaneously and the deer rolled over. He turned out to be a young buck, and there were two wounds in the hindquarters. We returned to camp feeling that there were several days' good sport ahead of us.

That night as we lay in bed we heard many strange noises. The far-away hoot of the great eagle owl was wafted to us on the night air; the night jar uttered his peculiar knocking call, which seemed to come from everywhere and yet from nowhere in particular; down by the stream the resonant croak of the mountain frog rose from the water's edge; but pleasantest of all to our ears was the barking of a roe-deer close on the slope behind our tent. 


\section{SINO-MONGOLIAN FRONTIER}

We were up before daybreak the following morning, and after a hasty breakfast started up the valley in search of wapiti. A long and strenuous climb brought us to the top of a high ridge between two peaks. Here the winter snows still lay deep on the shady side, and we could see the large fresh tracks of our quarry, and mark the spots where they had bedded down the day before. We climbed almost to the summit of one of the peaks, but finding no further tracks descended into a valley, along which we worked. Here I picked up a good fresh trail, and with Warrington keeping close behind me, followed it along the steep slopes. It led us across small ravines, round the shoulders of sharp ridges, over rocky screes, and through dense patches of hazel-scrub, but the trail grew ever fresher. At last as we topped one of the knifelike ridges, the graceful form of a large deer sprang from the scrub below us, and with long, easy bounds went sailing like thistledown across a wide ravine. Vainly we discharged our rifles again and again. Once the deer staggered, but recovering continued, till just as he reached and began to climb the opposite ridge, a shot from Warrington's rifle brought him to his knees. For a bit he struggled madly to continue, but presently lay quiet in some tall grass. Sending Warrington across to knife, if necessary, the wounded animal, I took up a commanding position upon the ridge, and prepared to intercept the deer if he attempted 


\section{SPORT AND SCIENCE ON THE}

to escape. Just as my companion reached the spot where our quarry lay, the latter sprang up and began to scramble down the hill. Not realizing the size of the animal, I called to Warrington to grab him. He managed to secure one hind leg, and for some minutes those of us who were watching, witnessed a desperate struggle between a not over big lad and a young wapiti stag the size of a mule. Hanging on like grim death, Warrington was battered about, and jerked backwards and forwards as the struggling deer kicked madly to free himself. He dragged his captor up and down the slope. Away above me I could hear Schröder's voice, "Stay with it, Freddie! Stay with it." Stay with it he did, and when the deer's struggles ceased for a moment, he let go the leg hold and planted himself firmly upon the animal's head. Scarcely was he seated, however, when the stag with a terrific heave sent him rolling head over heels down the slope. At this moment two beaters arrived on the scene. One of these incautiously tried to grasp the deer's hind leg, and received a kick in the pit of the stomach that ripped open his wadded clothes and sent him rolling to join Warrington at the bottom of the ravine. At last, however, the plucky creature was overcome by numbers and received the coup de grâce. On examination, we found that there were two wounds in the animal, so divided the honours, though Warrington's last shot brought it down. 


\section{SINO-MONGOLIAN FRONTIER}

The two beaters carried the carcase back to camp, while we made the circuit of one of the high peaks in search of more game. Nothing more was seen, however, except a few roe-deer, one of which I shot.

Schröder and Brodie: after witnessing the finishing of our wapiti, continued up over the top of the peak, and descended the other side into some favourable looking country. Here they caught sight of five wapiti feeding away down in a valley, and by dint of careful stalking managed to bag two. These were larger and older than the one we had already secured, but in no way remarkable. Unfortunately it was the wrong season for horns, in spite of the fact that the Chinese had told us that we might expect to find good heads. This being the case we decided to hunt no more wapiti, hoping some day to revisit the same country at a more propitious season. ${ }^{1}$

1 In November, 1913, the author, accompanied by Captain T. Holcomb of the U.S. Marines, visited some mountains in the Kuei-hua-Ch'êng district, said to contain wapiti. This information turned out to be correct, and they had splendid sport, securing five wapiti bucks, and several gorals.

One of the wapiti, shot by the Captain, had a really magnificent pair of horns, with twclve points, six and six, and measuring :-length along curve, right 41 inches, left $39 \frac{1}{2}$ inches; length, tip to basc, right 34 inches, left $31 \frac{1}{2}$ inches; widest spread $29 \frac{1}{2}$ inches; basal circumference, right $9 \frac{1}{2}$ inches, left 9 inches.

As is usually the case the deer were confined to a comparatively small area and frequented certain ravines and valleys almost exclusively. To exactly what species this 


\section{SPORT AND SCIENCE. ON THE}

We now turned our attention to the gorals, which from time to time had been seen. Schröder especially wanted to get one, and spent all his remaining time climbing difficult peaks in search of these elusive, chamois-like animals.

On the third day of our visit to this district Warrington and I determined to work a section of precipitous country, hitherto unexplored by any of the party. We climbed up a long, rocky ridge- - one of a series which radiated from a massive peak to the north of our camp. As we neared this peak, Warrington caught sight of a goodsized goral, which almost immediately vanished in a labyrinth of rocks. A difficult climb up the face of a perpendicular cliff brought us to a point above the rocks, amongst which we supposed the goat to be hiding. By throwing rocks and shouting we managed to drive out a fine roebuck, but there were no signs of the animal we were after. I gradually reached a point at the base of the peak, which rose above me in a precipitous wall of granite for six or seven hundred feet. Suddenly a shower of rocks scattering round me told us that the goral was somewhere on that rugged cliff, but Warrington, who was a hundred yards or so out from the base, could not make

deer belongs, it is impossible to say. It may turn out to be an intermediate form between the Manchurian wapiti (Cervus xanthopygus) and the Kansu wapiti (Cervus kansuensis). -A. de C. S. 


\section{SINO-MONGOLIAN FRONTIER}

out where he was. We determined therefore to work round the back of the peak in the hope of coming upon our quarry somewhere near the summit.

A long stiff climb brought us out upon the crest of the peak whence we could command a good view of the draws and ravines below us. Again we began hurling rocks and shouting, working gradually away from the peak down a high ridge to the east. Suddenly the goral darted out from the base of a cliff below us, and crossing the draw, hid up under a second low cliff on the opposite side. He was much too far away for a shot, so we decided to get nearer. Accordingly Warrington climbed down to a position exactly opposite the hiding goral, while I made a big detour and came up from behind to the top of the cliff above the animal. Just as I reached this point Warrington's rifle rang out, I could hear something moving in the bushes below me, but could see nothing. My companion tried to direct my gaze to the right spot, but the hazel-scrub was too thick for either of us to see our quarry. Presently with a rush the goral broke cover and went scurrying down the ravine. We both fired, but missed. Hurrying down the mountain side, I succeeded in heading him off, as he was trying to get back to the high ground. Again and again he doubled in an attempt to get past me, while every time I got a chance I fired. The 


\section{SPORT AND SCIENCE ON THE}

game was too strenuous, and at last I sat down on a spur of rock to recover my breath, with the goral somewhere in a ravine below me. The wily animal stole up from the ravine under cover of rocks and bushes, and actually passed within a few feet of me. As soon as he was past me he must have started running, for I heard a slight noise, and looking round, saw him scampering off up the ridge. Using a rock on which to rest my rifle, I tried several shots, but it was no use. The terrible strain I had undergone, tearing back and forth over the rough mountain side to keep the active animal from getting back amongst the peaks, had used me up and I could not steady my aim, and to my unspeakable chagrin and disappointment the goral escaped over the crest of the ridge. He passed Warrington and the beaters unobserved, and was well on his way to some high peaks behind the one where we had first surprised him, when he nearly fell foul of Schröder and Brodie. These two, with a couple of beaters, had been gradually working round towards us, when, hearing our shots, they sat down to see if any game would be driven their way. Presently they saw our goral come trotting along, heading straight for them. Just as he was within easy range one of the beaters coughed. Like a flash the active animal, rendered doubly so by his recent experiences with us, dodged behind some rocks. When next they saw him he was out of range climbing a distant ridge. 


\section{SINO-MONGOLIAN FRONTIER}

The following day I bagged a roe-deer with a very fine pair of horns. This set the others trying to secure good roe-deer heads. Brodie next bagged a large buck, whose horns, however, were in no way exceptional. The last day of our stay in this region Warrington succeeded in getting a pair of horns, which rivalled mine in length, but were not so well shaped. No one saw another goral, and finally we were forced to return to K'uei-hua-ch'êng without having secured one.

During our stay in these mountains I had my traps out, and secured a vole or two, together with some mice and rats. Nothing new was caught.

Though there was no large timber in this district, there was no lack of vegetation. Amongst other things we found a very delicious wild leek, which served well as a table dish. Wild rhubarb was also very plentiful, both here and in the mountains nearer K'uei-hua-ch'êng. We found this very palatable, and it served to eke out our fast diminishing store of canned fruit.

On June 1 we commenced our return journey to Kalgan. As our two companions, Schröder and Brodie, were not quite ready to leave, Warrington and I travelled alone. I decided to take the southern route (i.e. the route which passes south of the T'ai Hai).

Leaving K'uei-hua-ch'êng we travelled first due south and then south-west for seventy li, putting up at a village named Hsia-pu-na on the plain. 


\section{SPORT AND SCIENCE ON THE}

Here, we were surprised to learn, there were antelopes in the vicinity. We decided to stay for a day and try our luck with them.

Early the following morning we rode out, accompanied by a guide. We had not gone far when we suddenly came upon an antelope, which stood watching us at no great distance. Before we could get our rifles ready, however, he was off. A rapid shot only sent him flying like the wind. He seemed to stretch out along the ground, as he sped like an arrow over the sandy soil, and was soon out of sight.

Continuing, we put up a second antelope, which we followed up carefully. Finally I got a shot at him, and bowled him over. He seemed to rebound from the earth, however, and was off like a streak across a low ridge. Following him up, we soon found his trail marked with splotches of blood. For two hours we followed this, at last coming upon our antelope lying out on a sandy stretch. He sprang to his feet on seeing us, and once more started off at a good pace. Mounting our ponies, we foolishly gave chase. We could not overtake the wounded animal. With my glasses I had made out a big red patch on his side, showing where he had been hit. In spite of this wound he led us for a ten-mile run, finally eluding us in some broken country, where his trail got mixed up with a lot of others equally fresh, and the blood having long since ceased to 


\section{SINO-MONGOLIAN FRONTIER}

flow, we were unable to track him further. We saw several other antelopes, but were unable to get within range, so finally returned to Hsia-pu-na without having secured one.

It was still early in the day, so we decided to continue our journey for another half stage. Twenty li more of the plain, and we reached a deep and winding gorge in the mountains, up which we travelled till we reached a small village named Yang-p'o-yao-tzŭ. Here we put up for the night.

Up to this point the sides of the ravine were of basalt, showing the characteristic columnar cleavage, but from Yang-p'o-yao-tzŭ westward we travelled, next day, through a deep and narrow ravine in rugged mountains of granite. At noon, after crossing a high pass, we stopped at a large village named Ning-yüan, which contains about one thousand inhabitants, and is the seat of a small country official.

After leaving Ning-yüan and following the valley to its head, we crossed a second rather low pass and once more descended into the T'ai Hai basin, putting up for the night at a Catholic village named Hsiang-ho-ti, on the western shore of the lake. Here we met several of the Catholic priests, who, as usual, were very kind and courteous, giving us all the information we required about the district.

The following day, June 4, we skirted the southern shore of the lake, which extends in this direction 


\section{SPORT AND SCIENCE ON THE}

about forty li, finally reaching a large village named 'T'ien-ch'êng-ts'un, where we put up at a comfortable inn.

From this point westward to Yang-kao we traversed the same road as on our outward journey. At Fên-chêng we received word that Yang-kao had just been looted by mutinous troops. This made us somewhat anxious, but two days later, when we reached that town, we found that order had been restored, though all the tradespeople had been cleaned out, several streets burnt, and $\$ 12,000^{1}$ looted from the grain merchants.

As I wished to examine more carefully the geology of the country along the Chang-sui Extension line, I sent Warrington on by rail with our outfit, while $I$ took the three ponies and traversed the distance between Yang-kao and Kalgan by road. During this journey, which took three days, we experienced very bad weather indeed. Several severe hailstorms, followed by heavy rain, caused the Nan-yang Ho to swell, flooding the valley so that we could only proceed along the railway embankment. In one place where we were taking shelter under a railway arch, the hailstones, ranging in size from marbles to pigeons' eggs, lay from three to six inches deep, giving the effect of a heavy fall of snow.

${ }^{1}$ Owing to this town being the temporary terminus of the newly-opened Chang-sui Extension Line, an extensive trade in grain had sprung up, to carry on which the merchants had large sums of ready money in hand.-A. de C. S. 


\section{SINO-MONGOLIAN FRONTIER}

The grandeur of that storm as it rolled down from the north was superb. Heavy black clouds, lit up in places by the westering sun, whose bright rays they were about to cut off, came sweeping over the granite peaks and down the steep slopes, pouring out a white wall of hail, which seemed to pass like a scythe over the waving fields of early wheat. As the hurricane, driving before it the yellow dust from the road, and swirling mists of wind-sprayed rain, struck the tall poplars, they groaned, bent and cracked. The stout trunks of some snapped like matchwood; others were uprooted and hurled to the ground, where their leaves were soon stripped off and beaten into the soil. Telegraph poles went down in rows before the fury of that blast. As the heavy clouds came overhead the light grew dim; the rain and hail fairly shrieked as it thrashed upon the unyielding rocks, or churned the soft earth of the fields into frothy mud; jagged forks of lightning ripped through the inky pall, followed by the crash of thunder, which echoing and re-echoing through the ravines and gorges sounded like the roll of cannon in battle. Presently a dull persistent roar could be heard, which steadily increased in volume till it drowned all other sounds, and looking across the valley we saw a mighty rushing torrent sweeping all before it, and bearing upon its foaming surface trees, bushes and debris of all kinds. The terrified ponies whinnied and capered in their fear, but 


\section{SPORT AND SCIENCE}

finding that they could not break loose stood trembling under the shelter of the arch. So severe was this particular storm that the train, which had passed but a few minutes before, was held up at the next station, as the engineer feared that it would be derailed if it caught the full force of the gale when crossing the high bridges of the Tung and Hsi-yang Ho. At last the storm passed, and the sun, before it dipped behind the western peaks, shone through the mists, and bathed everything in gold. The purple shadows lengthened and the chill of night descended, as we sought shelter at the nearest station inn.

Next day, as the river was still in flood, we continued along the embankment, noting the devastation wrought by yesterday's storms. For miles the telegraph poles were down, while hundreds of fine trees had been laid low and already were being stripped of their branches and sawn up into logs. In one place a landslide, bringing down with it three mighty elms, effectually barred our path, necessitating a perilous detour into the swirling waters and sinking sands of the river bed.

At last we reached Kalgan, having accomplished our task, and I at once proceeded to Tientsin with my specimens. These I shipped to America before the end of the month, and having worked up the results of our observations, returned to Kalgan on July 10 ready to start a journey into Mongolia. 
THE MONGOLIAN PLATEAU 



\section{CHAPTER VII}

\section{THE MONGOLIAN PLATEAU}

TUY 15 saw us once more on the march. In Kalgan we had met Mr. F. A. Larson of the British and Foreign Bible Society, and he had very kindly lent us a cart and four ponies, together with the services of one of his Mongol servants, whom we called Wu Lama. This man spoke Chinese and was to act as guide to our party as far as Lama Miao, our objective. As our outfit was rather heavy, we had to hire another cart for the journey.

We started rather late in the day, so that we could only make 'T'u-ching-tzŭ that night. Our road lay north by north-west from Kalgan up a narrow valley, winding through the steep and rocky hills, which form a fringe to the great Mongolian Plateau.

Next day, after continuing up the valley ten li (3 miles) to its source, we began the difficult climb up the famous Han-nor-pa pass, which is one of the most rugged and hardest to negotiate in all North China. It took us five 


\section{SPORT AND SCIENCE ON THE}

hours to do the four miles to the top of the pass, by which time the animals needed a good rest, so once more we put up with a short day's run and decided to spend the night at a farm-inn named Huang-hua-p'ing.

On July 17 we made an early start, but heavy rains during the night had rendered the roads well nigh impassable, so that progress was very slow. We now headed in a northerly direction for a few miles, traversing low, rolling grasslands, cultivated here and there by Chinese settlers, whose farms could be seen dotted over the landscape. Several small lagoons were passed, whereon sheld-ducks and other water-fowl were plentiful. By nightfall we had done sixty li (about 25 miles), and put up at a small inn named Ts'a-han-k'u-luan. It must be stated that the li of the Mongolian Plateau are very much longer than those within the Great Wall. Sixty Mongolian li might be taken as the equivalent of eighty or ninety Chinese li. As far as we could make out the Mongolians themselves have no such standard of measurement, but measure distance by the time it takes a pony to do it, and reduce that to li. Thus in spring when the grass-fed ponies are lean and exhausted after the long winter, the distance in li between two places will be considered double or treble what it would be in the autumn when the ponies are fat and vigorous after a summer's rich feeding. It was some time before 


\section{SINO-MONGOLIAN FRONTIER}

we realized this, and as a result we were often very much confused at the answers we received when asking the distance to places.

Leaving Ts'a-han-k'u-luan on July 18, we continued over slightly undulating country till we reached a temple called Borrosun, where we stopped and had a cup of tea with a fat lama. Here we came upon the first Mongol encampments, for round the temple there were numerous tents, some of which were very fine indeed, denoting the presence of some petty chiefs. The lamas in the temple were very hospitable, serving us with their best and refusing with indignation our offer to pay for what we had received.

After leaving Borrosun we once more encountered cultivated fields and Chinese farms. Here wheat and mustard were being grown on a large scale. Sometimes a single field would stretch for a mile or more without a break. The Chinese settlers were all new in the country and many were still building shacks and huts to live in. We lunched at one of these farms, after which we continued in a north-north-easterly direction towards some low hills. As we crossed the first ridge of these we could see storm clouds gathering in the west, so that, when we reached a Mongol camp beside a small lake called Dahmun Nor, we hastened to pitch our tents. We were too late, however, and the storm struck us just as we had the first tent in position, but before it was pegged 


\section{SPORT AND SCIENCE ON THE}

down. Everybody and everything was drenched, and momentarily the wind threatened to carry away the tent, on to which we were all hanging for dear life. The storm did not last long, however, so that when we got the stove going we were able to get our clothes and belongings dry before nightfall.

We were now well into Mongol territory and could no longer expect to find inns or any shelter except that of our own tents. The Mongols along this route, owing to their continual intercourse with travelling Chinese, who are ever on the alert to cheat them, were inclined to be inhospitable even to us. They generally refused to sell us even the commonest commodities, such as milk and argol, except at extortionate prices, preferring to lose the sale rather than reduce the price quoted by a single cash. This attitude is scarcely to be wondered at, for it is the last resource of the poor Mongol against the cunning and avarice of the Chinese, who above all other peoples are skilled in the art of cheating and swindling. Even as it is, the Mongols for decades past have been cheated out of land and cattle till many of them are reduced to abject poverty. The Chinese trader or dealer makes his appearance amongst the Mongols bringing with him all sorts of articles that he knows will appeal to their simple minds. These he sells at excessive rates, and refuses to accept immediate payment. He 


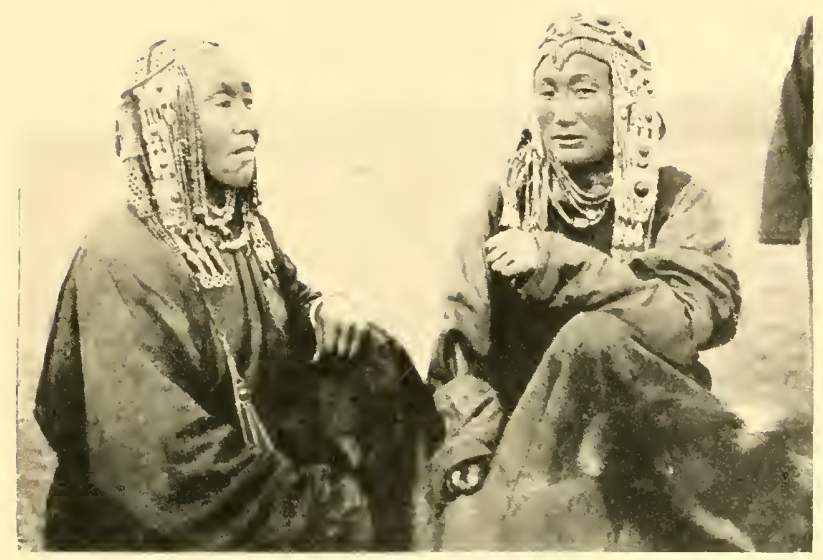

Mongol Women Wearing Full Dress Head-Gear of SilverMounted Coral and Turguoise.

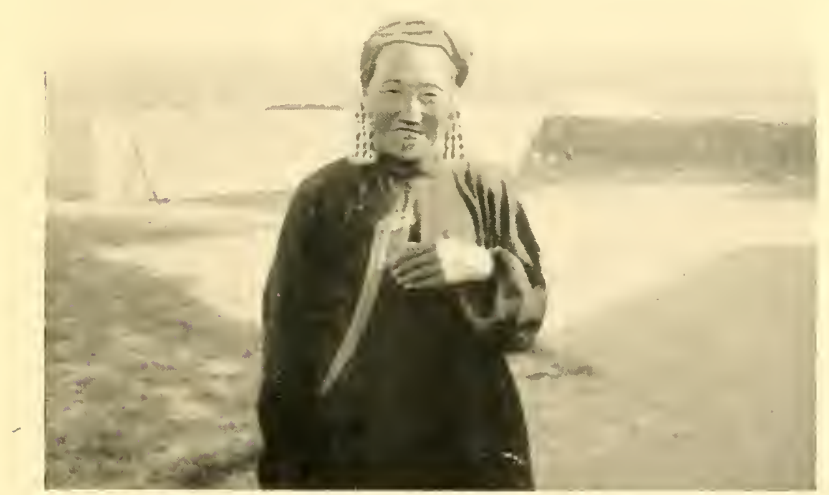

Mongol Woman in Ordinary Head-Gear. 



\section{SINO-MONGOLIAN FRONTIER}

waits till he fancies his victims are not in a position to produce the necessary silver and then comes down upon them demanding payment. The unsophisticated Mongols, being unable to meet their creditor's demands, allow him to pick from their herds. Needless to say, the trader takes the fullest advantage of this offer, and gets away with the pick of the herds at far below their worth, and the poor Mongols find themselves left without their best breeding stock, which they are unable to replace.

The same thing happens, only on a much larger scale, with regard to the land. In this case it is the princes and chieftains who sell their heritage for a mess of pottage. Thus there has sprung up between the Mongols and the Chinese a bitter hatred, which can only be wiped out with blood. On the one hand the Mongols preserve a sullen demeanour towards the Chinese, refusing them even the commonest civilities, treating them with overbearing hauteur and disdaining to hold any but the most necessary intercourse with them. The Chinese retaliate by driving harder bargains and getting the Mongols deeper into the toils of their usurious schemes, while amongst themselves they save face by heaping opprobrious epithets and vile names upon their victims.

The following day our road bore still more to the east. Shortly after leaving Dalimun Nor we saw some antelopes and at once set about 


\section{SPORT AND SCIENCE ON THE}

stalking them. By keeping behind a low hill, we got close to them, but failed to bring one down. Further on we saw a few more, but could not get a shot at them, as they were out on the flat plain. The country through which we were now passing consisted of wide, perfectly flat plains bounded by low, grass-covered hills. Here and there were the usual lagoons so typical of this country. The water in these is often brackish and always muddy, owing to the fact that the camels, horses and cows wade into it during the noonday heat to escape the cruel flies with which the country swarms.

Indeed, so numerous and annoying were the flies, that our ponies were driven to the verge of madness. These winged pests ranged from the size of midges to that of large wasps, and all bit and stung. There was one kind with a long hooked tail that had a predilection for settling upon the noses of our ponies. So much did the poor animals dread this variety (doubtless a species of Warble fly), that they would go frantic if one were hovering round, flinging themselves upon their knees and rubbing their noses in the sand or grass. At nights, when the ponies were turned loose to graze, the smaller varieties of flies would settle in swarms upon them, so that one could sweep them up in handfuls of juicy pulp. At nights, too, the flies were replaced by cruel stabbing mosquitoes, especially if we camped near marshy ground. 


\section{SINO-MONGOLIAN FRONTIER}

So tormented were our ponies that they could not find time to eat, while they tore the skin of their heads and necks into ribbons rubbing against the carts in frantic endeavours to find relief.

We stopped for lunch and midday rest at a large Mongol encampment named Oochinobar, where lived a local chief. This dignitary resided in a commodious brick building, though the rest of his people lived in the usual round felt tents. The chief sent us a present of cheese and sour cream. The latter went well enough on our bread, but the former was too full of hairs to recommend itself to us. However, at our request some bowls of fresh milk were brought, to which we did full justice. Night found us at another large temple named Marlagaisun, where we camped beside a fine well. Here we had some difficulty in obtaining fuel, but Wu Lama, by riding off to some Mongol camps, managed to secure a bagful of the precious commodity.

As is well known, the Mongols burn various kinds of cattle droppings, dried in the sun and called "argol." As they use only open stoves, it can readily be understood how important it is to get the stuff to burn with as little smoke as possible. To do this great care must be exercised in gathering, drying and stacking the droppings. Beside every camp one may see huge piles of argol as large, if not larger, than the tents themselves. These consist mainly of cow droppings, which form 


\section{SPORT AND SCIENCE ON THE}

an excellent and comparatively smokeless fuel, if treated in the right way. We found it burned well in our stove, giving out much heat.

The temple at Marlagaisun is typical of those prevalent in Mongolia. We were told that it harboured about seven hundred lamas, but this statement is hard to believe, though in any case the number was very large. On our journey in this region we passed no less than seven such temples, not including the two big ones at Lama Miao, and as each temple had hundreds of lamas, drawn from the surrounding encampments, it can be imagined why the Mongols are dying out. These lamas are entirely supported by contributions from the lay Mongols, and being a lazy, good-for-nothing lot, act as parasites, sucking the very life-blood out of the nation. The rule of the leading lamas is absolute over the people. It is kept up by skilful play upon the intense superstition and religious fanaticism of the Mongol nature, and it is probable that in no country in the world are the people so bound by priesteraft as in Mongolia. In addition to their despotic and parasitical rule, they have, by their vile and filthy lives, introduced amongst their people the scourge of terrible diseases, against which they have no remedy.

Can anything be more pitiful than the picture of this wretched people, by nature open-hearted, frank and intensely religious, degraded by a 


\section{SINO-MONGOLIAN FRONTIER}

religion, itself sunk from lofty heights of philosophy into something little better than demon and lust worship, burdened with a host of sensuous priests, who spend their time between debauch and futile prayer, scourged by loathsome diseases, cheated and robbed by the emissaries and traders of a grasping neighbour on the south, and threatened, though they know it not, by a slavery worse than that of the Israelites in Egypt by an equally greedy neighbour on the north ? ${ }^{1}$ And yet it was this same people that under the famous Genghis Khan swept Asia and Eastern Europe in a stupendous conquest such as the world has never seen before or since. One may safely say that under a morally and socially sound government, freed from their superstitions and the burden of priestcraft, the Mongols would once more rise to be a great nation, filling a special place-the conquerors of the deserts-in the world's economy. One cannot help wondering whether they are destined to fill that place, or, like their blood relations on the American Continent, are doomed to be exterminated by the onward march of civilization.

A call comes ringing over the deserts of Central Asia from the dwellers in the tents of Mongolia to the enlightened and humanitarian Powers of the West to help them in this their hour of need. Will those Powers answer the call and see that 1 This menace no longer exists. 


\section{SPORT AND SCIENCE ON THE}

the Mongols are allowed that independence for which they are fighting? Will they keep within their borders those wolfish neighbours, either of whom, if they could embrace Mongolia in their cruel grasp, would assuredly crush the life out of her people? Will they send men to teach them the laws of hygiene and clean living, men to fight the ravages of disease, and men to give them a pure and uplifting religion? Or will they leave them to become a prey to intrigue, treachery and their own degrading worship?

Such thoughts as these crossed my mind, as I sat in the cool evening at the tent door, gazing upon the lofty pinnacles and quaint roofs of the great temple, silhouetted against the glowing western sky, and heard the dull roar of the great trumpets and the dismal wail of the priests at their vespers. The afterglow faded into night and the doleful dirge of the priests died away, and all was peace and calm, as the myriad stars peeped forth, and we turned in to enjoy a good night's rest.

From Marlagaisun we travelled still northeastward, reaching by noon a Chinese farm named Kao-chi-ke-san. Here for a distance of a few miles the country was under cultivation. We saw some more antelopes, but again failed to secure one. In the afternoon, after leaving the cultivated area behind, we encountered more hilly country, where some more antelopes were seen, one of which Warrington succeeded in bringing down. I 


\section{SINO-MONGOLIAN FRONTIER}

wounded another, but the best efforts of our ponies failed to run him down. He led us into the hills, where we saw several small herds, which, however, we were unable to approach. We decided to camp in the vicinity, so pitched our tents beside a small encampment named Borlien, and spent the next two days hunting antelopes.

We met with only moderate success, Warrington securing two antelopes. On one of our rambles, while we were sitting on the hillside, two wolves sprang up from the long grass below us. We tried several shots, but failed to bring one down. As in the mountains west of K'uei-hua-ch'êng, we found the distances very deceptive, objects always appearing much nearer than they really were. We might have secured some more good heads in this district if we had known more about the habits of our quarry. As it was, during the two days we spent here we saw numerous small herds, which, however, we found the greatest difficulty in approaching.

Leaving Borlien on July 23 we continued in a north-easterly direction up a long, narrow valley, in which were large herds of camels, fattening up on the luxurious grass for their winter's work. The bellies of some of these were enormously distended, and the humps of all of them were erect and full, showing a good store of nutriment already laid by. By noon we reached a small river, crossing which, we soon came upon 


\section{SPORT AND SCIENCE ON THE}

a vast herd of antelopes, numbering several hundreds. We could not get nearer than about four hundred yards, so we tried several long shots. In this way I succeeded in securing one antelope-my first. Warrington shot another a little later. It was a wonderful sight to see so many antelopes, all tearing across the rolling prairies. Our firing made them split up into small herds, usually led by large does, and soon they were scattered for miles in every direction.

That night we reached Chinese settled country once more, putting up at an inn named Ha-pach'iao. Here our road joined the main KalganLama Miao road, which we had left soon after leaving Huang-hua-p'ing, at the edge of the Mongolian Plateau. We had followed what is commonly known as the Mongol road, which lies to the north and west of the other, and has for its chief attraction the fact that there are fewer Chinese settlers, so that one can see more of the Mongols in their native haunts.

From Ha-pa-ch'iao to Pei-sui Nor, our next day's journey, the road lay all the way through Chinese farms.

On July 25 we reached Lama Miao, after a short run from Pei-sui Nor of not more than twentyfive li. We pitched our tents on an open grassy stretch between the town and the two great temples, from which the place gets its name.

Lama Miao Ting, or Dolon Nor, is an extensive 


\section{SINO-MONGOLIAN FRONTIER}

Chinese settlement composed mainly of squalia mud buildings, divided by filthy, slushy streets. Here and there are a few more pretentious houses of brick, though even these are badly built. There are a great many shops, which cater for the growing needs of the Mongols. The inhabitants are chiefly engaged in trading with the latter, exchanging grain and manufactured articles for such raw material as wool, skins, hides, and also horses and cattle. On the whole the town is very uninteresting.

On the other hand, the temples situated about a mile from the town are well worth a visit. They differ but little from the Lama Temple in Peking, with their extensive courtyards and wide and lofty halls, decorated with rich tapestries and gaudily painted idols, and hung with drums, trumpets, cymbals and gongs. There in a corner stands the great prayer wheel, which reels off a hundred or more prayers a minute, according to the energy of him who adopts this method of supplication. At the doors of the courts sit blind lamas, who, for a small consideration of a cash or two, will save him even that trouble, by revolving at a great speed miniature models of the great prayer wheel.

We arrived in Lama Miao just in time to witness the annual devil-dance, a most important function of a religious nature, which draws crowds of Mongols from all the surrounding districts. It 


\section{SPORT AND SCIENCE ON THE}

began on July 26 and lasted three days. At about ten o'clock in the morning we went to one of the temples to watch the proceedings. Since dawn great crowds of Chinese had streamed past our tents towards the temples, while we could see caravans of Mongols flocking in from every direction. These now mingled in one great concourse in and round the temple precincts. The Mongols were dressed in flowing robes of brilliantly coloured silks, especially the girls and young women. These, resplendent in their beautiful dresses, heavily decorated and braided with gold and silver, moved about in little bevies, laughing, chatting and exchanging greetings with their friends and acquaintances. From their heads, which were adorned with beautifully worked caps and hats, hung the most gorgeous head-dresses of delicate silver tracery, holding together great strings of coral, turquoise and amber beads. Sometimes they hid these glories under bright scarlet, green or yellow kerchiefs, from which their pretty, mischievous, smiling faces peeped out, and if they did not cause an extra flutter in the hearts of the young bucks standing round, it says much for the stolidity of the Mongol.

When two parties met, an elaborate business of exchanging snuff bottles by way of greeting took place; nor was the ceremony complete till every member of one party had exchanged snuff bottles with every member of the other. 


\section{SINO-MONGOLIAN FRONTIER}

The Mongols seemed to appreciate the religious significance of the function, and one and all went into the temples to perform little acts of worship, such as the tolling of a bell, the lighting of a candle, which they bought from the priest at an exorbitant price, or the prostrating of themselves before the great Buddha, which sat, sublimely indifferent, at the head of the hall. The Chinese on the other hand were little more than sight-seers, only a very few performing any acts of worship.

Outside the temple there were peep-shows, conjurers and quack medicine sellers, one of whom advertised the efficacy of his wares by cutting himself with a knife and stopping the flow of blood by the application of a white powder. This he subsequently sold at the rate of three packets for four cents. He netted about twenty cents, after having talked for an hour, and made an incision in his thigh half an inch deep and three inches long. How often he repeated this performance during the day it would be interesting to know. There were, besides, the usual medley of food-stalls and tea-booths.

On entering the temple a brilliant scene unfolded itself before us. Hundreds of brightly clad Mongols swarmed across the courts, up the great flight of stone steps and into the lofty prayer hall. Following the crowd, we entered the hall. Here all was confusion, as the lamas were busily engaged in shifting great pieces of furniture 


\section{SPORT AND SCIENCE ON THE}

into position for the coming ceremony. Presently some little boys, dressed up as living skeletons and ferocious demons, appeared upon the scene, and with long canes began to drive out the Chinese and lay Mongols.

Leaving the hall, we took up our stand upon a side verandah, and prepared to take snapshots of the proceedings. Presently the great twentyfoot trumpets began to blare out their mournful dirges, to the accompanying boom of colossal drums. A long, low wail rose from the lamas, sitting upon little mats in long rows between the great red pillars of the prayer hall. Every now and then the wail would rise into a mighty volume of sound, while trumpets, smaller than the great roaring instruments on the balcony above, would add their clarion notes to the swelling chorus of wild music. Then again all sound would gradually die away to a dull drone, like that of a hive of bees on a summer's day, only to rise once more till the great hall would ring again. All this while the little skeletons and demons were flitting about amongst the gay crowds, striving vainly to keep order, while ever and anon a fat priest would sally forth and take a look at the rapidly darkening sky.

Soon the rain began to fall, at first a gentle sprinkle, then a steady shower, which finally developed into a tropical deluge. As if by magic the great courts were cleared of the yellow and 
PLATE $\mathrm{X}$.

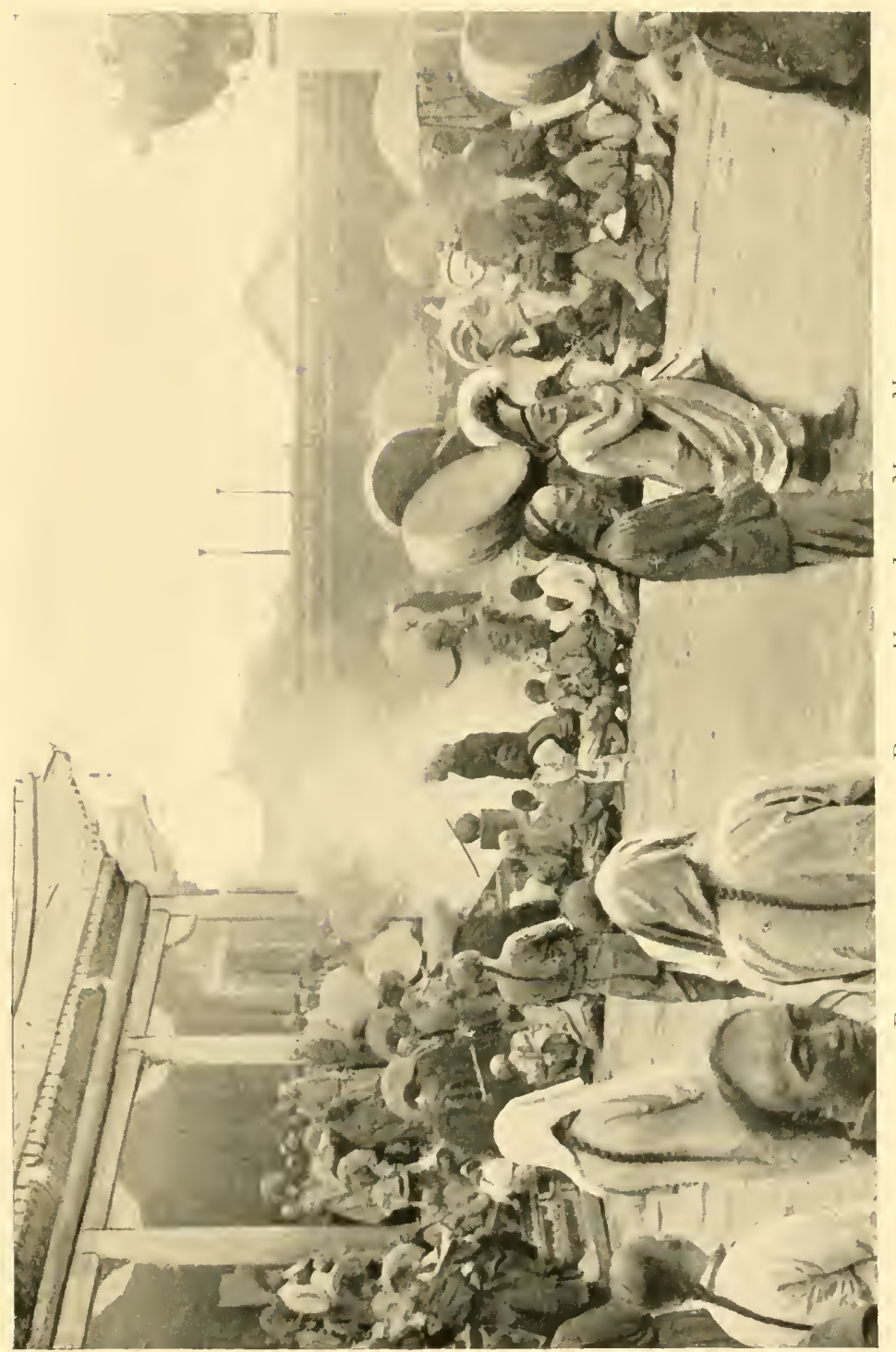

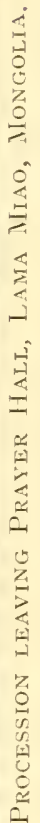





\section{SINO-MONGOLIAN FRONTIER}

red lamas, the laughing bevies of Mongol damsels and the blue-gowned Chinese, while the little devils were jostled about, much to their annoyance and disgust, as the crowds, regardless of blows and curses, sought shelter upon the extensive verandahs of the prayer hall. It rained for an hour, during which time the mournful dirges continued unabated. At the end of that time the clouds dispersed and the lamas, dressed in long, yellow robes and high, helmet-like caps, issued from the hall in a double line. Two, bearing a tall, pyramidshaped object, surmounted with a grinning human skull, preceded the rest. They walked side by side bearing aloft the object of veneration, in such fashion that it passed over the heads of a long line of kneeling Mongols.

Having arrived at the outermost court, the long procession of monks found to its dismay that it was flooded a foot deep with water. This brought the proceedings to a close, so we returned to camp, without being able to watch the actual devil dance. From what I could gather the devil dance itself would have been a sight well worth seeing. It is performed by lamas and acolytes dressed up as skeletons, demons and mythical beasts such as dragons, unicorns and horned lions. The dancers draw up and execute figures not unlike those in some of our dances, to the accompaniment of cymbals, gongs, drums and trumpets.

The following day it rained incessantly, but 


\section{SPORT AND SCIENCE ON THE}

on the 28th it cleared up long enough for the annual races to be held. We witnessed these, and were much amused to see Chinese grooms from Shanghai dressed in all the splendour of their European masters' cast-off riding clothes, racing neck and neck with gaudily dressed Mongols. A good turf track had been marked out, supposedly the size of the Shanghai course, and the races were conducted as nearly as possible on the same lines as those at the Treaty Port meetings.

These races are not to be compared with the long twenty, forty or sixty li races indulged in by the Mongols, in which the jockeys are young boys and girls, who ride bare-backed. Unfortunately we just missed seeing one of these proper races, which took place at a neighbouring chief's encampment a few days later. Regarding one of these races we were told an amusing story. A certain Mongol chief offered a prize of one hundred taels (about $£ 15)$ to the winner of a fifty li race (about fifteen miles). He also offered a second prize of twenty taels. The race was to be between two camps along a certain route not yet specified. It so happened that in the district there was a pony which hitherto had remained unbeaten. On the day of the race the owner of this pony was purposely given wrong instructions as to the route to be taken, being directed to take a rough and roundabout way to the winning post. All the 


\section{SINO-MONGOLIAN FRONTIER}

other competitors, including the jockeys of the chief's own race ponies, were of course directed along the correct route. At the given signal the ponies dashed off on their long cross country race, the champion well in the lead. To the surprise of every one this pony, after taking the long route, arrived at the winning post before any of the others were in sight. The owner naturally claimed the first prize, but the wily chief got out of the difficulty by disqualifying the pony for the first prize, because it had taken the wrong course; but he very graciously awarded it the second prize. The first prize went to the owner of the second pony reaching the winning post, which in this case happened to belong to the chief himself.

The night after the races was spent by us in great anxiety, as the rain fell in torrents hour after hour, and we were momentarily threatened with inundation. A small, dry, stream bed, which looked harmless enough when we camped upon its bank, now assumed the proportions of a river, the edge of which crept slowly to within a foot of our tent. Every moment I expected the banks of the main stream above us to give way and flood the plain. At about ten o'clock we heard a cry, and rushing out were just in time to rescue a luckless carter and his oxen from drowning in the torrent that rushed past our tent. The wheels of the carts were washed away, but the bullocks, aided by us, were able to drag the empty wagons to the shore. 


\section{SPORT AND SCIENCE ON THE}

The carter afterwards told us, as he sat drying himself over the stove, that he had driven carts to and fro across this creek bed all his life and had never known it like this before.

We struck camp next day with a view to finding safer camping ground, but in crossing the main stream experienced the misfortune of having our cart capsize. Everything was soaked, and it was with difficulty that we saved several articles, which were being swept away on the flood. This catastrophe necessitated our returning to Lama Miao, where we put up at an inn and managed to get our things dry. Unfortunately a whole set of photographs of the races and scenes at the devil dance was ruined.

Next day, July 30, we left the vicinity, striking due west towards some unusually high hills. The heavy rains, as usual, had damaged the roads, so that we experienced great difficulty in climbing the slopes of the hills. Finally we pitched camp in a green pasture near the top of the divide. Here there was an unusual amount of vegetation, and we were surprised to find roe-deer in the district. A badger was also seen, besides some partridges. This was the highest point we reached on the whole journey, the top of the divide being about 5,000 feet above sea level and 1,000 feet above Lama Miao.

The following day we descended once more on to rolling grasslands, reaching by mid-afternoon 


\section{SINO-MONGOLIAN FRONTIER}

a rather large river called Chanding Gol, which we afterwards found out was the continuation of the river we crossed two days before reaching Lama Miao. We had great difficulty in crossing it, in its present swollen state, but finally succeeded without mishap, and, traversing some ugly swamps, pitched camp within the ruins of an ancient town called Sui-lang-ch'êng. The walls of this place were now only grass-covered mounds, while a grassy hummock in the centre marked the site of the central tower. Otherwise there was not a sign of former buildings. These ruins it is believed date from the time of the Grand Khan Kublai.

From Sui-lang-ch'êng we continued our journey a little south of west, crossing low divides and wide valleys, and camping at suitable wateringplaces. Nothing of peculiar interest occurred. The long grass round the wells and Mongol camps was found to give shelter to numbers of hares, while now and then we would get a shot at an antelope. Warrington succeeded in getting a nice head one day with a good pair of horns. Crossing a low divide we saw a fine buck silhouetted against the evening sky. It was Warrington's turn to have a shot, I having wounded and lost a nice animal the day before. Accordingly he left his pony with me and climbed to the point where the antelope had disappeared. He was lucky enough to find on the other side a herd of ten or a dozen 


\section{SPORT AND SCIENCE ON THE}

bucks, two of which he bowled over. He emptied his magazine trying to get a third, but failed to do so. Without re-charging his rifle he went to examine the two antelopes he had dropped. One of these jumped up and bounded off after the rest of the herd as though unhurt. When I arrived on the scene it was too late to do anything, especially as there was no blood trail to follow.

Between Sui-lang-ch'êng and Tabool, which place we reached on August 7, our stopping-places were Harborrogar, Tavunghaila, Nartainchao, Oola Hutaga and Hoborrow, all of which, except the last, were small Mongol camps. Hoborrow is the seat of a petty chieftain. We stayed one day at Oola Hutaga on account of rain. Here the hills are high and inclined to be rugged.

Tabool or Tabo Ola (meaning Five Hills) is the summer home of our friend, Mr. F. A. Larson, ${ }^{1}$ whose work is amongst the Mongols. On our arrival we received a very warm welcome from this kindly missionary family. It had been my purpose to make a collection of mammals in this district, so we gladly accepted a kind invitation to stay as long as we could. A fine large Mongol tent was placed at our disposal, and throughout our stay we were very comfortable.

We at once set out a lot of traps, and were re-

1 Mr. Larson subsequently held for a time the position of adviser on Mongolian Affairs to the Chinese Government on aecount of his intimate knowledge of the country and its people. He now holds rank in Mongolia equivalent to that of a Prince. 


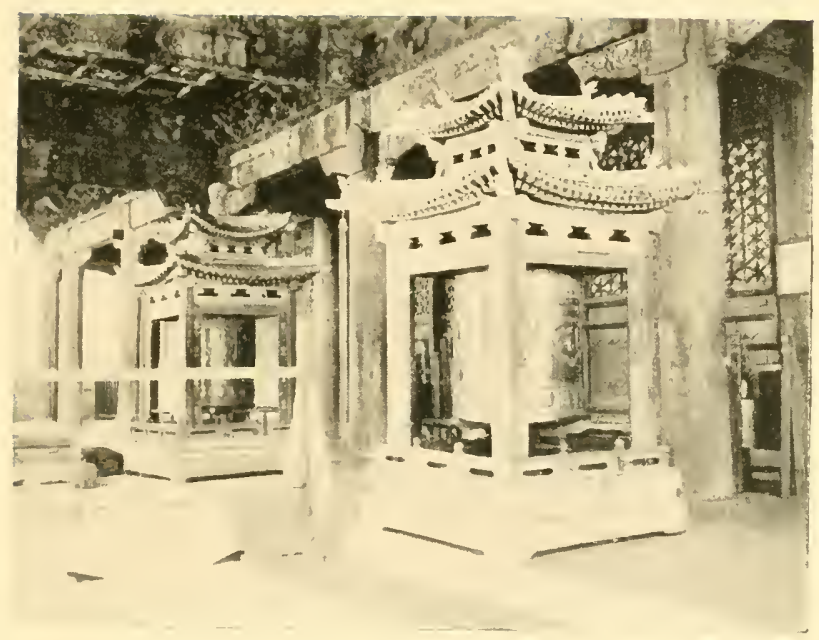

Big Prayer Wheel, lama Miao, Moxgolia.

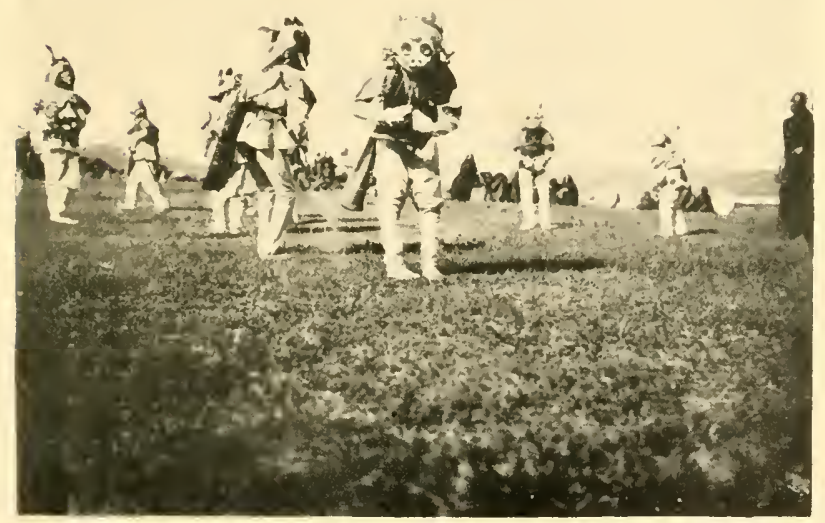

Devil-DaNcers, LaMa MiaO, Moxgolia. 



\section{SINO-MONGOLIAN FRONTIER}

warded with a good collection of small mammals, including about ten different species, namely, the hare (Lepus tolai), the pika (Ochotona dauurica), the allactaga (Allactaga mongolica), the gerbil (Meriones unguiculatus), the suslik (Citellus mongolicus umbratus), the striped hamster (Cricetulus griseus obscurus), Campbell's hamster (Phodopus campbelli), two voles (Microtus angustus and Microtus warringtoni) and the common mouse (Mus wagneri mongolium).

Mr. Larson very kindly placed his ponies at our disposal, our own being rather worn out with the long journey, and he arranged for several very successful antelope hunts, so that we secured eight good skins for our collection. Altogether we shot eleven antelopes.

The method adopted by our Mongol guides in hunting these antelopes gave us excellent sport and required good horsemanship, a quick eye and rapid and accurate shooting. Following is a typical example of a day's hunting in these parts.

Starting early in the morning we rode westward for a mile or so till we reached Mr. Larson's herd of ponies, where we changed our mounts. For a few minutes there was a scene of confusion as the herders chased the chosen ponies, but at last they were caught and saddled, and away we rode toward some low, rocky hills. How those ponies flew! regardless of holes, rocks, tufts of " nigger head" or swamps! They took everything in I6r 


\section{SPORT AND SCIENCE ON THE}

their stride, while to right and left as we passed through clumps of sage brush or sedge grass, the startled hares skipped out of our way, or the ground squirrels dived into their holes, giving shrill little shrieks of indignation and kicking up spirts of sand behind them. In an amazingly short time we had covered the five or six miles to the hills, climbing which, we obtained an extended view of the valleys and plains. Soon we spotted a herd of antelopes. These caught sight of us almost as soon as we saw them, and splitting up they made off at top speed. Warrington, Larson and one of the Mongols went off after the main herd, while I, with the other Mongol, followed two fine-looking bucks, that had broken away in another direction. It must be understood that the plains are gently undulating, so that hollows and low eminences alternate like the great rollers of the gently heaving ocean. Presently our two antelopes disappeared into one of these hollows. At once we urged our ponies to their utmost, and by so doing gained considerably upon our quarry without alarming them further. When next we caught sight of them, they were not more than eight hundred yards distant.

They now cut a semicircle round us and once more started off, soon being lost to view in another hollow, along which they travelled at an easy trot. Taking a parallel hollow, we again pressed our ponies, gaining another two hundred yards 


\section{SINO-MONGOLIAN FRONTIER}

upon the antelopes, before we saw them again crossing the low rise between the two hollows. By remaining perfectly still we escaped observation. The moment the antelopes were out of sight, we again set spurs to our ponies. After a short sharp gallop I dismounted and crept up to the top of the rise, but did not fire as my quarry were still rather far, and were trotting gently along the next rise. By galloping, hiding and scouting in turn we arrived at last within easy range and I took a shot. I hit the antelope, but did not drop him. Just at this moment a large herd swept by, from which I bagged a second antelope. My Mongol went after the first animal, which at once set off towards the hills, and, easily out-distancing his pursuer, hid amongst some rocks and sage brush. An hour or more we spent in searching for the wounded animal. The Mongol climbed to the top of the highest peak in the little range, from which point of vantage he made out the tiniest movement in some sage brush fully a mile distant. Returning to where I was waiting he directed me to the right spot, and before long I had the satisfaction of bowling over my buck, as he sprang up from the brush and made for the adjacent ridge. My companions also succeeded in wounding an antelope, which, however, escaped and was not secured till next day.

One day while out with us, Mr. Larson surprised and shot a badger, which he presented to our 


\section{SPOR'T AND SCIENCE ON THE}

collection. This with the antelopes brought our collection of mammals up to twelve species.

On finding that my traps were being robbed of their catches, I baited one with the remains of a pika, and next day had the satisfaction of putting my hands on the robber, a beautiful, white-headed falcon. I tried to tame this bird, as I had done a young golden eagle we had picked up one day. My efforts proved a failure, so at last I gave the bird his liberty once more. On another occasion we found a sheld-duck in a hole in some rocks. It was long past the breeding season, but from the down and grass in the hole, we came to the conclusion that this was her nest. Subsequently we verified the facts that the ruddy sheld-duck nests in holes in rocks at no small distance from water, while the common sheld-duck nests in long burrows in the banks of the lagoons so common throughout this country.

A few birds were added to our collection which, however, were in very poor feather. There were also some nice butterflies to be seen, amongst which was a rather fine swallow-tail.

While staying with Mr. Larson we had several opportunities of watching the Mongol cowboys at their work in sorting, catching, branding and breaking the wild little ponies in their herds. Instead of a lariat or lassoo, the Mongol uses a long twenty-foot rod, little thicker than a fishing rod, at the end of which is a looped thong of raw- 


\section{SINO-MONGOLIAN FRONTIER}

hide. With this he is very dexterous and can soon eatch the wildest pony. Slipping the loop over the pony's head while going at top speed, the rider gives it a twist to prevent it slipping. Then he jumps on to his own pony's crupper, bracing his thighs against the back of the saddle. His mount at once slows down, and it is a strong animal, that being thus caught, can continue to drag his captors about or break the raw-hide thong. Some of these cowboys are so dexterous that they can put a complete halter upon the pony they are after, by a double turn of the wrist as they slip the loop over the animal's head.

Branding and saddling are simple processes and are done without throwing the pony. Often a pony shows great fight when being broken, and being small, with a very short neck, is very hard to manage. Still the Mongols are superb horsemen and seldom let an animal get the better of them.

Mr. Larson, who for fifteen years has travelled about amongst the Mongols, and who is greatly respected and looked up to by them, introduced us to some of his neighbours and friends. These simple, kindly people treated us with great hospitality whenever we had occasion to drop into one of their tents for a drink of milk. Always the best they had was produced. Cheese and cakes would be spread before us, and though it was only with the greatest difficulty that we could 


\section{SPORT AND SCIENCE ON THE}

bring ourselves to partake of these unwholesome looking delicacies, we always did our best for fear of offending our hosts. The one thing that I could not accustom myself to was mare's milk, though Warrington always managed a good big bowl of it; while Larson thought as much of it as the Mongols themselves did. Mare's milk is thicker than cow's milk and has a sour taste even when quite fresh. It is just as though some citric acid were put into ordinary milk. This milk is very much more sustaining than cow's milk, it being possible for a man to subsist on it entirely, at the same time doing a strenuous day's work. We were told that the Mongol cavalrymen, when on service, used mares and could live entirely upon their milk. If this be true one can readily see how useful they could become in military operations in such a country as Mongolia.

All the Mongols in this district live in tents, which they move from time to time within a prescribed area. They often stay two, three or even eight years in the same spot. Their tents consist of wooden skeletons, the sides of which take the form of circular trellis work fences capable of being extended or drawn in, and the roofs of which resemble nothing so much as the framework and ribs of an immense umbrella. Over the whole sheets of wool felt are laid and tied in place by horse-hair ropes. These tents are capable of resisting very severe weather and extremely low I66 


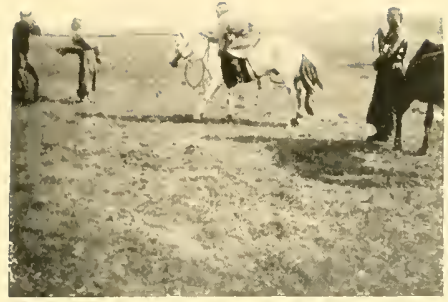

Pony Lassoed.

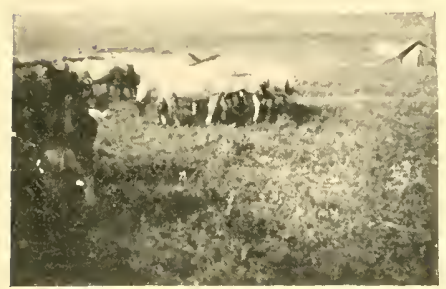

A Herd of Mongol Ponies.

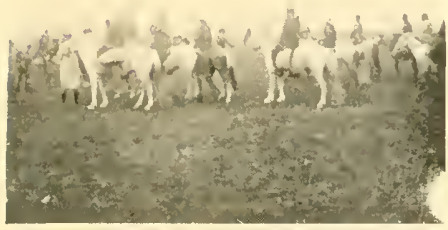

Watching the Races.

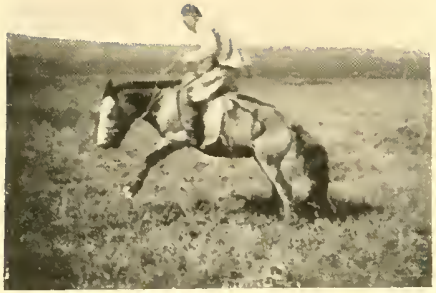

Breaking a Wild Pony.

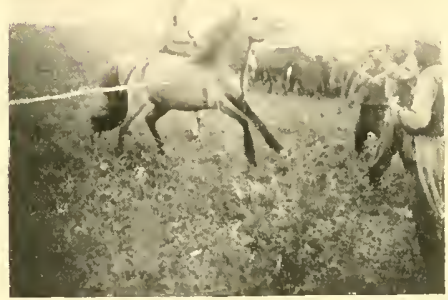

Examining Teeth of Wild Pony.

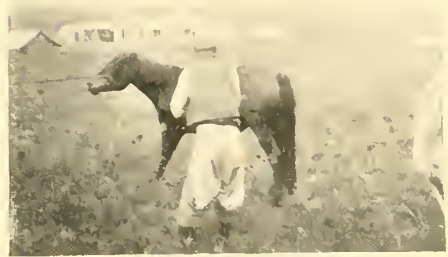

Branding Willd Pony. 



\section{SINO-MONGOLIAN FRONTIER}

temperatures. Indeed they must needs be so, for the plains are swept in summer by terrible storms, such as that described in the preceding chapter, while in winter the temperature falls below zero. A single low door in each tent affords ingress. The floors are of beaten cowdung, and are usually raised slightly in the centre, where an open iron stove holds the smouldering argols. In the tents of the wealthier Mongols there is a raised dais on the side away from the door, upon which the lord himself sleeps or the honoured guest is seated on elegant woollen rugs, while he sips salted and buttered tea. Round the sides of the tent are neatly placed small cupboards and red lacquer boxes, in which the household belongings are kept, while on the walls hang small mirrors, guns and powder-horns, whips, hobbles and other articles of daily use. The walls and roofs are always jet black from the smoke, which on fine days is allowed exit through holes in the roof. The inmates sleep round the fireplace on skins and felts.

For a living these Mongols raise horses and cattle almost exclusively, never cultivating the soil like those we saw in the Southern Ordos.

The district round Tabool is known as the Imperial Pastures, and is well suited to stock-raising. Though included on the map in the province of Chihli this district comes under the Banner of the Chagars. 


\section{SPORT AND SCIENCE ON THE}

The whole country from Lama Miao to Tabool reminded me of the North West Territories of Canada, with its stretches of rich and rolling grasslands, its numerous small lagoons and swamps and its herds of grazing stock, or, where the Chinese had settled, its wide expanses of wheat and mustard, growing luxuriantly upon the easily turned black mould.

The outcome of the present struggle for the ownership of this land cannot be foretold, but whoever gets it will be in possession of a fine territory, only waiting to be developed, by the sinking of deep and permanent wells and a system of irrigation, into the richest pastures, or the most fertile arable land. From the point of view of the agricultural development of this land, it would undoubtedly be best for the Chinese to secure it; but one would hate to bid farewell to the picturesque Mongols, and to see these wild, though simple, horsemen driven from this their heritage by the materialistic, sordid race whose proper home is south of the Wall.

We spent a very busy, but pleasant, fortnight at Tabool, after which we packed our things and began our return journey to Kalgan. Travelling in a southerly direction, we soon encountered Chinese settlements once more, and perforce bade farewell to the free grassy plains of Mongolia. From sixty li south of Tabool to the edge of the Plateau the land is all under cultivation. We 


\section{SINO-MONGOLIAN FRONTIER}

spent the first night at a wayside inn called Ma-ni-t'u.

The following night we put up at a large village called Miao-t'an, after an uneventful journey.

Next day we passed the ruins of an ancient town called Hsin-hua-ch'êng. Here in a temple yard we saw two large automobiles and a wagon. One of the former was painted a bright yellow and had a figure of the Imperial Dragon on its sides. The others were painted grey. On inquiry we were told that they had been placed there in October, 1911, in readiness to carry the Manchu Imperial Family to Urga, in case the Revolutionaries ever succeeded in driving the Manchus from Peking. These fine vehicles now lay unsheltered and uncared for, rapidly falling into decay, sad emblems of the fallen Manchu dynasty.

August 21 found us once more in Kalgan, and two days later we reached Tientsin and the end of another year's travel, sport and adventure on the Sino-Mongolian Frontier. 

BIOLOGICAL WORK 



\section{CHAPTER VIII}

\section{BIOLOGICAL WORK}

THE biological work done on the journey made 1 by Mr. Anderson and myself through Shensi, along the Ordos border and back into Shansi, resulted in some very interesting discoveries. No fewer than eight new species and five new subspecies were described by Mr. Oldfield Thomas of the British Museum from our collection of mammals. The descriptions of these, together with the names of and notes on the other twenty species represented, were published in the Proceedings of the Zoological Society of London, 1908, pages 963 to 983 . A detailed list would therefore be superfluous here, though the following general remarks may be of interest to the reader.

As Mr. Thomas pointed out, the most striking feature of the mammalia of the districts adjoining the Ordos is a general paling of colour, as compared with the nearly related species of the non-desert regions further south and east. This is especially noticeable in the Ordos chipmunk (Eutamias 


\section{SPORT AND SCIENCE ON THE}

asiaticus ordinalis), the hare (Lepus swinhoei subluteus), and the North Shensi sulphur-bellied rat (Epimys confucianus luticolor), and is undoubtedly due to the general pale buff colour of their sandy or loess surroundings.

Amongst the most interesting species in the collection were the three-toed jerboa (Dipus sowerbyi), and the little sand hamster (Phodopus bedford$i \propto)$, both of which inhabit exclusively the sands of the Ordos, and both of which show to a marked degree the light sandy colouring. On the other hand species such as David's squirrel (Sciurotamias davidianus), the three voles (Microtus johannes, M. (Caryomys) inez and Craseomys shanseius), the little wood pika (Ochotona sorella), the wood mouse (Apodemus speciosus peninsulæe), and Anderson's hamster (Cricetulus andersoni), all of which inhabit the forested and mountainous districts of Western Shansi, show none of this paling of colour.

Another interesting feature in the mammalia of these regions is the extreme scarcity of Insectivores. The only member of this group secured on this journey was the hedgehog (Erinaceus miodon), while the only other Insectivores hitherto secured in or near the desert regions are the mole (Scaptochirus gillesei) and a shrew (Crocidura sp.), from the T'ai-yüan $\mathbf{F u}$ plain in Shansi. It is interesting to compare the paucity of this class of mammals on the north-western border of China, 


\section{SINO-MONGOLIAN FRONTIER}

with their comparative abundance in the not very distant districts of South-western Kansu, Ssŭchuan, Corea, and the Japanese Islands. Recently Mr. Anderson has collected no fewer than nine species of shrews, and two moles, besides the remarkable Neotetracus sinensis from the province of Ssŭ-chuan and the neighbouring districts of South-western Kansu. Previous to this he collected three species of shrews and two moles in Corea, and no less than eight species and subspecies of moles, and eleven species and subspecies of shrews in Japan and the neighbouring islands.

Judging from what we know of the climatic conditions of these several districts, one is naturally led to suppose that Insectivores require a country with a humid atmosphere, and damp, well vegetated soil wherein to thrive.

This is not so much the case with rodents, so that we find this class of mammals greatly predominating throughout the whole region along the Sino-Mongolian borderland. Of the thirtyone species secured on our journey, twenty-five were rodents, represented by three hundred and twenty-four specimens, while the seven remaining species, including a bat (Myotis sp.), the hedgehog (Erinaceus miodon), a cat (Felis catus), a wolf (Canis lupus tschiliensis), a fox (Vulpes vulpes), a marten (Martes flavigula borealis), and a badger (Meles leptorhynchus), were represented by only seventeen specimens. One mammal seen, but 


\section{SPORT AND SCIENCE ON THE}

not secured, was the antelope (probably Gazella subgutturosa).

The Ordos hedgehog (Erinaceus miodon), which was one of the new discoveries of this expedition, is a light-coloured species, closely related to the Chihli and Shantung form, $E$. dealbatus. Its chief characteristic is that it has "no wholly white spines intermixed with the brown-ringed ones." This hedgehog seems to belong exclusively to Mongolia, as we never heard of it south of the Wall. The nearest locality in Shensi at which hedgehogs have been secured is Pao-chi in the Wei River basin, where Father Hugh discovered a new species ( $E$. hughi), named after him by Mr. Thomas. The food of the Ordos hedgehog seems to consist of beetles, numerous varieties of which swarm over the sandhills.

The badger from this district is identical with Meles leptorhynchus described from Peking. This animal exists all over North China and is very common in certain places. The Chinese value dressed badger skins, which make excellent dampresisting rugs. The Manchurian hunter wears a badger skin hanging from his waist at the back, thus ensuring a dry seat when out in the snows and rains. The badger is a great robber of melon patches and maize fields, in search of which he will travel long distances during the night.

Amongst the chipmunks obtained by us two new subspecies were discovered, namely, Eutamias 


\section{SINO-MONGOLIAN FRONTIER}

asiaticus intercessor and E. a. ordinalis. Of these the latter is a pale desert form found on the borders of the Ordos, the former being intermediate in colour between $E$. $a$. ordinalis and $E$. $a$. senescens from Chihli. The chipmunks are beautiful little creatures, making lively and entertaining pets. They are to be found all over the hilly and mountainous districts of North China, in some places being extremely abundant.

The sulphur-bellied rat (Epimys confucianus luticolor), secured near Yen-an Fu in Shensi, turned out to be a new subspecies. These rats are inhabitants of the rocky valley sides and ravines in the loess country. They are characterized by the pale sulphur yellow colour of their belly fur, their long white-tipped hairy tails and large ears. The chief subspecific characteristics of the Shensi form are its pale colour and delicate build, differing from true confucianus in the first respect and from the Shantung from $\boldsymbol{E}$. c. sacer in the second.

The next new subspecies is the giant hamster (Cricetulus triton incanus), which differs from the Chihli and Shantung species in being of a paler colour and of a less heavy build. This rodent is very common in certain districts. It lives in burrows, which go down into the earth in a straight, perpendicular, smooth, round shaft. Like all hamsters, this animal has a predilection for storing grain, which it steals from the farmers' fields. 


\section{SPORT AND SCIENCE ON THE}

Another hamster which was a new discovery has already been mentioned. The little sand hamster (Phodopus bedfordice), whose home is in the sand of the Ordos, is one of the most beautiful little creatures imaginable. It makes an excellent pet, being absolutely fearless of man, even when just caught. Amongst themselves these little creatures are terrible fighters. Originally placed in the genus Cricetulus, it was subsequently placed by Mr. Miller in a new genus of its own, called Phodopus, owing to the coalescence of the lobes on the sole of the foot into one ball.

Microtus johannes, a hill inhabiting vole from Western Shansi, was another new species, as also was Microtus (Caryomys) inez, another small vole from the same locality.

Of the two species of molerat (Myospalax cansus and $M$. fontanus), the latter from Ning-wu $\mathbf{F u}$ was first identified as $\boldsymbol{M}$. fontanieri, but has since been described as a new species. The other species found in Shensi and the Ordos seems to be identical with Lyon's Kansu variety.

The Ordos jerboa (Dipus sowerbyi) was also a new discovery on the expedition, it being entirely different from anything of the kind hitherto found in Eastern Asia. Its nearest ally in these parts is the allactaga (Allactaga mongolica), a single specimen of which was secured at Ningwu Fu.

The Shensi and Ordos hare (Lepus swinhoei 


\section{SINO-MONGOLIAN FRONTIER}

subluteus) was described as a new subspecies, its distinguishing feature being a general paling of colour.

The two remaining species in the collection, which were new to science, are two pikas, Ochotona bedfordi and $\boldsymbol{O}$. sorella, both described from the Ning-wu Fu district in Shansi. The first is a large pika allied to $O$. dauurica from the Mongolian Plateau, but with larger bullæ and slightly larger in size. In colour it is slightly paler than the Mongolian form. In habits the two animals are very similar. Some pikas caught at Yen-an Fu in Shansi were also referred to this species, but a specimen in its winter coat secured by me near Yen-an Fu, on the Clark Expedition, was distinctly paler and less yellow than a specimen from Ning-wu $\mathrm{Fu}$ district taken by me on our expedition up the Fên $\mathrm{Ho}$ in the winter of 1909-10.

The other pika (O. sorella) was trapped by me in a wood. It is a very small, dark-coloured species, nearly related to $O$. cansa from Kansu.

The next collection from North China was that made on the Clark Expedition from September, 1908, to the same month in 1909. The details of this collection were published in Through Shên$K a n$, and may be found in the appendix attached to that book.

Owing to unavoidable delay, the description of the new roe-deer, Capreolus melanotis, secured 


\section{SPORT AND SCIENCE ON THE}

in Kansu on this expedition was not published in time to be embodied in the volume already mentioned. This roe-deer was described in the Proceedings of the Biological Society of Washington, Vol. XXIV, pp. 231-232, by Mr. Gerrit S. Miller, Jr., who says : "Resembling Capreolus bedfordi in essential characters, including the hypsodent form of the teeth, but colour of summer pelage more reddish, and outer surface of ear mostly clear black, in striking contrast with surrounding parts." The type specimen was an immature female collected thirty miles east of Ching-yang Fu, Kansu, China.

After the Clark Expedition, my wife and I made collections in the T'ai-yüan $\mathrm{Fu}$ district, during the months of October and November, 1909. Details of these collections appear hereafter in this chapter.

Subsequently in the course of the journey made by us up the Fên Ho, a most interesting collection was made. This journey intersected that made by Anderson and myself at Wu-tsai Hsien and Ning-wu Fu, but it so happened that while my wife and I made a large collection at Wu-tsai Hsien, and secured nothing at Ning-wu $\mathrm{Fu}$, the very reverse was the case with Anderson and myself. On the Wu-tsai plain the species collected, with but few exceptions, were identical with many of those already secured in and round the Ordos. 


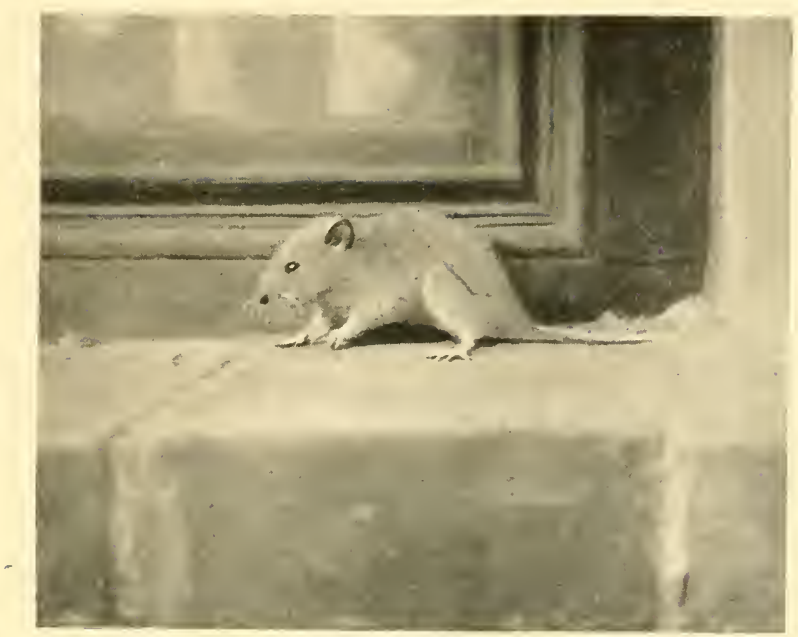

Giant Hanster (Cricetulus triton incanus).

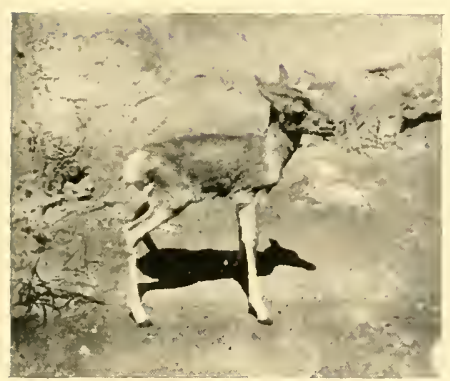

Young Antelope.

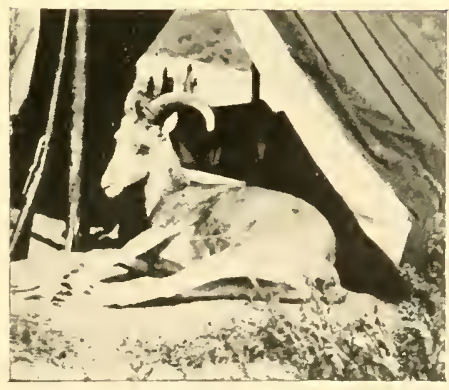

Wild Sheep. 



\section{SINO-MONGOLIAN FRONTIER}

The biological work of the year ending in August, 1912, as might be expected, was very much hampered by the unsettled state of the country. From October 27, 1911, to May 10, 1912, more than half the year, not a single specimen was added to my collection, except three antelope skulls, which I purchased in the Tientsin game market. Subsequently we tried to make up for lost time, making collections during the summer in North Shansi and on the Mongolian Plateau. Altogether from October, 1909, to August, 1912, about two hundred and seventy specimens of mammals were collected, including forty-five species and subspecies.

Very little was done in the way of collecting birds or cold-blooded vertebrates, while invertebrates were left entirely alone. It was unfortunate that I could not do more in these branches of zoology, but reptiles and amphibeans were almost non-existent in most of the localities visited. It was only in Mongolia that insects were at all plentiful, and while travelling in that country I had my time occupied with other important work.

Following is a list of the different species and subspecies of mammals obtained on the various expeditions subsequent to the Clark Expedition. For the sake of the general reader I have given popular names of my own to distinguish the different forms. 


\section{SPORT AND SCIENCE ON THE}

1. Hedgehog. Erinaceus dealbatus, Swinhoe.

2. Mole. Scaptochirus gillesei, Thos.

3. Shrew. Crocidura sp.

4. Leopard. Felis fontanieri, M.-Edw.

5. Marten. Martes flavigula borealis, Radde.

6. Siberian mink. Mustela sibirica, Pallas.

7. Small mink. Mustela sp.

8. Polecat. Mustela larvata, Hodgson.

9. Badger. Meles leptorhynchus, M.-Edw.

10. Wolf. Canis lupus tschiliensis, Matsch.

11. Fox. Vulpes vulpes subsp.

12. Flying squirrel. Sciuropterus sp.

13. David's squirrel. Sciurotamias davidianus, M.-Edw.

14. Chipmunk. Eutamias asiaticus intercessor, Thos.

15. Mongolian suslik. Citellus mongolicus umbratus, Thos.

16. Large gerbil. Meriones auceps, Thos.

17. Sand gerbil. Meriones psammophilus, M.Edw.

18. Mongolian gerbil. Meriones unguiculatus, M.-Edw.

19. Common house mouse. Mus wagneri mongolium, Thos.

20. Sulphur-bellied rat. Epymis confucianus luticolor, Thos.

21. Woodmouse. Apodemus speciosus peninsula, Thos.

22. Giant hamster. Cricetulus triton incanus, Thos. 


\section{SINO-MONGOLIAN FRONTIER}

23. Anderson's hamster. Cricetulus andersoni, Thos.

24. Striped hamster. Cricetulus griseus, M.-Edw.

25. Mongolian striped hamster. Cricetulus griseus obscurus, Thos.

26. Campbell's hamster. Cricetulus campbelli, Thos.

27. Desert hamster. Phodopus bedfordice, Thos. 28. Mandarin vole. Microtus mandarinus, M.Edw.

29. Light-coloured mountain vole. Microtus johannes, Thos.

30. Dark-coloured mountain vole. Microtus pullus, Miller.

31. Mongolian narrow-headed vole. Microtus angustus, Thos.

32. Mongolian camp vole. Microtus warringtoni, Miller.

33. Shansi red-back vole. Craseomys shanseius, Thos.

34. Ning-wu molerat. Myospalax fontanus, Thos.

35. Mongolian allactaga. Allactaga mongolica, Radde.

36. Sowerby's hare. Lepus swinhoei sowerbyoe, Hollister.

37. Mongolian hare. Lepus tolai, Pallas.

38. Duke of Bedford's pika. Ochotona bedfordi, Thos.

39. Mongolian pika. Ochotona dauurica, Pallas. I83 


\section{SPORT AND SCIENCE ON THE}

40. Wood pika. Ochotona sorella, Thos.

41. Wild pig. Sus sp.

42. Wapiti. Cervus canadensis subsp.

43. Roe-deer. Capreolus bedfordi, Thos.

44. Wild sheep. Ovis jubata, Peter.

45. Goitred antelope. Gazella subgutturosa.

Following are details concerning the specimens of the above listed species and subspecies collected since October, 1909, and sent to the Smithsonian Institution, Washington.

1 Erinaceus dealbatus, Swinhoe.

One specimen, $\hat{\sigma}$. Tientsin, Chihli. Almost sea level.

This hedgehog was first described by Swinhoe from Peking. It is comparatively common round Tientsin, where it is revered by the natives as a "Great Spirit." Owing to this fact it enjoys immunity from molestation. The Chinese name is "T'si wei," meaning "thorny animal" (T'si = thorn, wei = animal).

2 Scaptochirus gillesei, Thos.

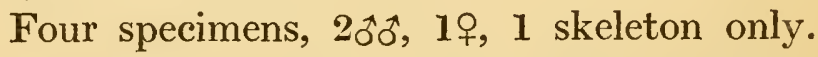
Wu-tsai, 20 miles $W$. of Ning-wu Fu, Shansi. $6,000 \mathrm{ft}^{1}$

Moles seemed to be rather abundant on this plain. The specimens secured were

${ }^{1}$ Probably overestimated. 


\section{SINO-MONGOLIAN FRONTIER}

brought in by the natives. This mole has also been recorded from Yü-lin $F u$, on the border of the Ordos, from T'ai-yüan Fu, in Shansi, and from South Shansi. It was originally described from the last mentioned place.

Its Chinese name is " $\mathrm{Ti}$ chu," meaning "ground hog" ( $\mathrm{Ti}=$ earth, ground; chu = pig, or hog).

3. Crocidura $s p$.

Three specimens, 2추수 1 우 (immature). 5 miles S. of T'ai-yüan $\mathrm{Fu}$, Shansi. $2,600 \mathrm{ft}$.

Owing to the immaturity of these specimens it has been impossible to identify them with any hitherto known species. They appear to be most like Crocidura corea, which species is found in the neighbouring province of Chihli. Shrews are evidently very scarce in Shansi, no other specimens having yet been recorded.

4. Felis fontanieri, M.-Edw.

One specimen from near T'ai-yüan $\mathbf{F u}$, Shansi.

The skin and skull were purchased from a native, so that no flesh measurements could be taken. The leopard is comparatively common in the mountains of Shansi, being I85 


\section{SPORT AND SCIENCE ON THE}

much hunted for its fine coat in winter. It is also found in Shensi, Kansu, Ssŭ-chuan, Chihli and Honan.

Chinese name $=$ Pao-tzŭ.

5. Martes flavigula borealis, Radde.

One specimen. No measurements. T'aiyüan $\mathbf{F u}$, Shansi.

This specimen also was secured by a native hunter. The marten is a handsome animal, with dark grey-brown upper parts, bright yellow throat and black legs and tail, the latter being long and bushy. About the size of a large cat, this animal is very savage, and commits serious depredations upon the chicken roosts of the villages. The marten inhabits almost exclusively the loess hills. The Chinese always refer to it as the animal that "eats cats."

Its Chinese name is Huang yao, (Huang = yellow, yao $=$ marten).

6. Mustela sibirica, Pallas.

Two specimens, 웅 5 miles S. of T'ai-yüan Fu, Shansi. 2,600 ft.

One specimen, ô. Tientsin, Chihli. Sea level.

This mink is found all over North China, but is especially common round towns in low-lying, swampy districts. It frequents I 86 


\section{SINO-MONGOLIAN FRONTIER}

human habitations, where it preys upon rats, mice and the occupants of the poultry yard. This mink has nothing to boast of in the way of fur, but skins are shipped in great numbers from North China to Europe under the name of weasel.

The Chinese name, "Huang hsu lang," means "Yellow rat wolf."

7. Mustela $s p$.

One skin from the Ning-wu district in West Shansi.

A small musteline, closely resembling in colour the foregoing species, but having a much shorter tail. As yet this specimen cannot be identified.

8. Mustela larvata, Hodgson.

Three incomplete specimens (two skins and one skull). Wu-tsai, 20 miles W. of Ning-wu Fu, Shansi. 6,000 ft. (?)

These specimens were indistinguishable from those secured in Kansu on the Clark Expedition, though the winter fur showed a distinct lightening in colour, one skin being almost white. So far, this species has not been discovered east of the Wu-tsai plain, though the natives of K'uei-hua-ch'êng, North Shansi, described an animal very similar to this polecat. 


\section{SPORT AND SCIENCE ON THE}

Chinese name in Kansu, "Sao-hu-tzŭ," meaning "Ermine fox"; in Shansi, Ngai ho (ho = ape or monkey).

9. Meles leptorhynchus, M.-Edw.

One specimen, ô. Tabool, 100 miles N. of Kalgan, Mongolia. 4,000 ft.

The single specimen of the badger was shot and presented to my collection by Mr. F. A. Larson. While in the Tabool district we saw several badgers, but they always succeeded in escaping into their holes before we could capture them. We also failed to secure any with traps.

The Chinese name is "Huan-tzŭ."

10. Canis lupus tschiliensis, Matsch.

Two specimens, 우으. Wu-tsai, 20 miles $W$. of Ning-wu Fu, Shansi. 6,000 ft. (?)

Wolves in this district were very common, and stories of their depredations came to our ears continually. Fourteen were seen on the journey, but they were nearly always out of range of my rifle. The Chinese distinguish two varieties, named respectively "ts'ai" and "lang." The former refers to the smaller and more yellow-coloured wolves; the latter to the large grey animals, which do so much damage to the village livestock, and frequently attack human beings. 


\section{SINO-MONGOLIAN FRONTIER}

The wolves "seen in the extreme north of Shansi were large and of a very pale colour, with long hair. Two seen on the Mongolian Plateau near Lama Miao were, on the other hand, rather dark, though in size they surpassed the Shansi variety. The winter skins from K'ou-wai, that is beyond the northern passes of China, meaning Mongolia generally, command a much better price in the fur market than do the skins from China proper. They are of a far better quality, the hair being longer, thicker and softer, and usually of a much lighter colour. These skins also are generally larger than those from further south.

11. Vulpes vulpes subsp.

Three specimens. One skull, 20 miles S.W. of Ning-ivu Fu, Shansi. 5,700 ft.

One skull, and one complete specimen, ô. Wu-tsai, 20 miles W. of Ning-wu Fu, Shansi.

The fox, like the wolf, has a very wide distribution in North China. Annually great numbers of skins are exported from Tientsin.

Its Chinese name is " Hu li " or " Hu-tzŭ."

12. Sciuropterus sp.

Nine specimens, 4 ธิธิ, 5 우우. Mountains 10 miles S. of Wu-tsai, Shansi. Altitude, $8,000 \mathrm{ft}$. 


\section{SPORT AND SCIENCE ON THE}

One skin and skull, without measurements, was received from a native hunter who said it came from about 70 miles N.N.IV. of T'aiyüan $\mathrm{Fu}$-this would be about the same locality as the above. It was at first thought that this was a new form, but Büchner's description of a species from Kansu so exactly agrees with it, though from so widely distant a locality, that our species cannot be separated, at least, till specimens from both places have been compared. A somewhat rare animal, it is found only in the largest forests of the high mountain ranges, where it hides in holes in trees, coming out only in the evening. These squirrels are difficult to trap and are not easily kept alive in captivity. The latter fact is due doubtless to the difficulty in supplying their natural diet.

The Chinese name "Fei-hsu" means "Flying rat." (Fei = to fly; hsu = rat.)

13. Sciurotamias davidianus, M.-Edw.

Five specimens, 웅 50 miles N.W. of 'T'aiyüan $\mathrm{Fu}$, Shansi. $5,500 \mathrm{ft}$. and $6,000 \mathrm{ft}$. Four specimens, 2 ธิธิ, 2 우우. Mountains 70 miles N.N.W. of T'ai-yüan Fu, Shansi. $7,000 \mathrm{ft}$.

The first specimens of this very widely distributed squirrel were obtained by myself ; the other four by a native hunter. All came 


\section{SINO-MONGOLIAN FRONTIER}

from the same general district, where they are very common.

14. Eutamias asiaticus intercessor, Thos.

Four specimens, 2 ธิ乛ే, 2 우오. Mountains 50 miles N.N.W. of T'ai-yüan Fu, Shansi. $6,000 \mathrm{ft}$.

One specimen, 오. Mountains 70 miles N.N.W. of T'ai-yüan Fu, Shansi. 7,000 ft.

One specimen, ㅇ. Mountains 30 miles W. of K'uei-hua-ch'êng. North Shansi. 7,000 $\mathrm{ft}$.

As already stated, the chipmunk is an intermediate form between that of the Ordos (Eutamias asiaticus ordinalis) and that from the mountains west of Peking (E.a. senescens).

Its Chinese name is "Ke li."

15. Citellus mongolicus umbratus, Thos.

Four specimens, 웅․ 20 miles W. of Lama

Miao, Mongolia. 4,000 ft.

Two specimens, 우. 50 miles $\mathrm{W}$. of Lama Miao, Mongolia. 4,000 ft.

Six specimens, $\widehat{0} \widehat{0}$. Tabool, 100 miles $\mathbf{N}$. of Kalgan, Mongolia. 4,000 ft.

This ground squirrel, which closely resembles the species from China proper and the Ordos, is extremely common throughout the region we traversed. The six specimens 


\section{SPORT AND SCIENCE ON THE}

from Tabool are topotypes, the subspecies having been described by Mr. Thomas from specimens taken by Anderson in this district.

One of the four specimens taken 20 miles west of Lama Miao, inside the ruins of Sui-langch'êng, is remarkable in having a much greyer and softer pelt than any of the others. At first sight I took it to be a totally different animal, but from an examination of its skull and its other characteristics it seems to belong to the same species.

The Chinese name is "Sha hsu," meaning "Sand rat" (Sha = sand; hsu = rat).

16. Meriones auceps, Thos.

Five specimens, $1 \hat{\delta}, 4$ 우우. Wu-tsai, 20 miles W. of Ning-wu Fu, Shansi. 6,000 ft. (?)

Originally described from the T'ai-yüan $\mathrm{Fu}$ district, Mr. Thomas says of it: "Of the other Chinese Meriones described, this very pretty species may be distinguished from $M$. unguiculatus by its whitish claws, buffy ears, whiter bullæ, and less blackened tail; from $M$. psammophilus by its larger size and buffy ears ; and from both by its enormously large bullæ, which indicate that it is not really closely allied to either of them."

This species is purely nocturnal in its habits, which may account for the "enor- 
PLATE X̃IV.

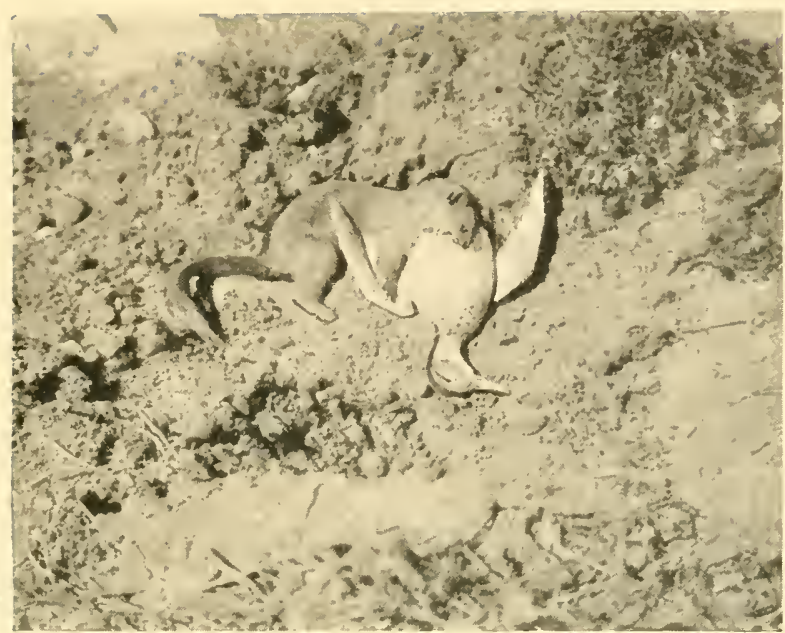

Mink (Mustela sibirica) Eating Teal.

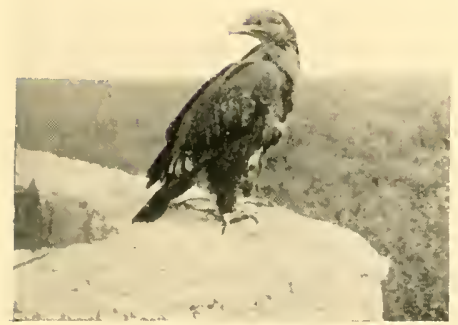

Golden Eagle.

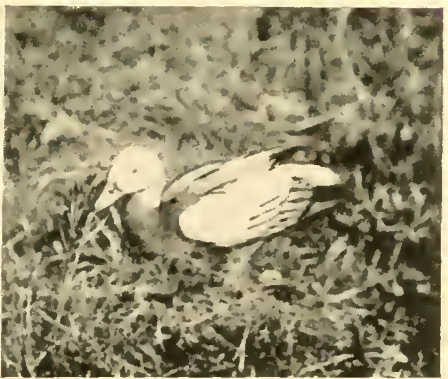

Ruddy Sheld-Duck. 



\section{SINO-MONGOLIAN FRONTIER}

mously larger bullæ," than in the other two species, of which $\boldsymbol{M}$. unguiculatus is entirely diurnal and $\boldsymbol{M}$. psammophilus partly so.

M. auceps has also been recorded from North Shensi, as well as from the Ordos Desert itself.

Chinese name "Huang hsu," meaning "Yellow rat."

17. Meriones psammophilus, M.-Edw.

Eight specimens, 6 " $0 \hat{\sigma}, 2$ 우우. 5 miles $\mathrm{S}$. of T'ai-yüan $\mathrm{Fu}$, Shansi. $2,600 \mathrm{ft}$.

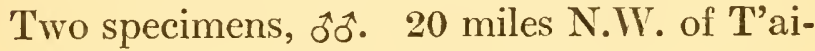
yüan Fu. Shansi. $3,950 \mathrm{ft}$.

A very common species in these districts. It inhabits sandy places, from which fact it derives its name. It is smaller than either of the other two gerbils already mentioned, though in colour it more closely resembles M. auceps.

Chinese name as in $M$. auceps.

18. Meriones unguiculatus, M.-Edw.

Two specimens, ô, ㅇ. Tabool, 100 miles N. of Kalgan, Mongolia. 4,000 ft.

This gerbil differs from the first named species in being of a more sandy colour, in the absence of the white underparts, and in the smaller bullæ. It is found in the Ordos Desert and in Northern Shansi, as well as in 


\section{SPORT AND SCIENCE ON THE}

the present district. In the first named country it is very common, often living in large colonies. It is diurnal in its habits.

19. Mus wagneri mongolium, Thos.

Three specimens, 2 ถิ소, 1 우. 5 miles S. of T'ai-yüan Fu, Shansi. $2,600 \mathrm{ft}$.

Six specimens, 2 충서 4 우우. Tabool, 100 miles

N. of Kalgan, Mongolia. 4,000 ft.

The second series of mice is topotypical, the subspecies having been described from this locality by Mr. Thomas, from six specimens taken by Mr. Anderson in 190\%. As Mr. Thomas points out, it is darker than $\boldsymbol{M}$. wagneri from Central Asia. $\boldsymbol{M}$. wagneri mongolium occurs all over North China, and is very common.

20. Epimys confucianus luticolor, Thos.

Five specimens, 1 ô, 4 웅․ Lung-wang Shan, 20 miles E. of T'ai-yüan Fu, Shansi. 4,000 ft.

Three specimens, 1 ô, 2 우. Mountains, 50 miles N.W. of T'ai-yüan Fu, Shansi. $5,500 \mathrm{ft}$.

One skull, + , one complete specimen, $\delta$. Mountains 30 miles W. of K'uei-huach'êng, N. Shansi. $7,000 \mathrm{ft}$.

Usually common in rocky ravines in mountainous country, this rat enjoys a wide dis- 


\section{SINO-MONGOLIAN FRONTIER}

tribution. It is a very voracious animal, and readily eats its companions when trapped. In certain parts where the natives lay their dead in holes along the rocky valley sides these rats live upon the corpses. While in North Shansi we heard a gruesome tale, how a lonely mountaineer fell ill and before help came was horribly gnawed by these rats. The subspecies was originally described from Yen-an Fu.

21. Apodemus speciosus peninsulce, Thos.

Thirteen specimens, 5 추수, 8 우우. Lungwang Shan, 20 miles E. of 'T'ai-yüan Fu, Shansi. 4,000 ft.

Four specimens, 2 ㅊํ, 2 우오. 50 miles N.W. of 'T'ai-yüan Fu, Shansi. 5,500 ft.

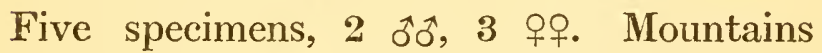
30 miles W. of K'uei-hua-ch'êng, N. Shansi. $7,000 \mathrm{ft}$.

The last five specimens all agree with the others taken further south in Shansi and those recorded from Shensi, which have been referred to this subspecies. So far this is the most northerly point from which this species has been recorded. It is one of the commonest inhabitants of the mountainous and wooded areas, and is found at altitudes varying from $3,000 \mathrm{ft}$. to $8,000 \mathrm{ft}$. It was first described from Corea. 


\section{SPORT AND SCIENCE ON THE}

22. Cricetulus triton incanus, Thos.

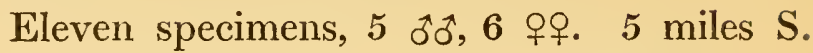
of 'T'ai-yüan Fu, Shansi. 2,600 ft.

Three specimens, $2 \hat{\jmath} \delta \hat{\jmath}, 1$ ㅇ. Lung-wang Shan, 20 miles E. of T'ai-yüan Fu, Shansi. 4,000 ft.

One specimen, ㅇ. Mountains 50 miles N.W. of 'T'ai-yüan Fu, Shansi. $5,500 \mathrm{ft}$.

A very common species upon the T'ai-yüan $\mathrm{Fu}$ plain, where it does much damage to crops. It was originally described from Shansi.

Chinese name, "Pan ts'ang êrh (Ts'ang = store)."

23. Cricetulus andersoni, Thos.

Seven specimens, 3 ิㅜㅇㅅ, 4 우우. 5 miles $\mathbf{S}$. of 'T'ai-yüan Fu, Shansi. 2,600 ft.

Three specimens, 2 ธิธิ乛ี, 1 우. Lung-wang Shan, 20 miles E. of T'ai-yüan $\mathrm{Fu}$, Shansi. 4,000 ft.

Seven specimens, 3 ô수, 4 우우. 50 miles

N.W. of 'T'ai-yüan Fu, Shansi. $\quad 5,500 \mathrm{ft}$.

This hamster is very common throughout Shansi and Shensi. Recorded also from Kansu.

24. Cricetulus griseus, M.-Edw.

Seven specimens, 6 ธิธิ乛, 1 ㅇ. Wu-tsai, 20 miles W. of Ning-wu Fu, Shansi. $6,000 \mathrm{ft}$. I 96 


\section{SINO-MONGOLIAN FRONTIER}

This species seems to replace $C$. andersoni on the Wu-tsai plain, and other non-mountainous districts of North China. In habits the two closely resemble each other. Griseus has a shorter tail and is characterized by a dark median dorsal line, otherwise closely resembling andersoni.

25. Cricetulus griseus obscurus, M.-Edw.

Two specimens, 중우. Tabool, 100 miles $\mathrm{N}$. of Kalgan, Mongolia. 4,000 ft.

Milne-Edwards described a hamster from Sartchy (or Saratsi or Sa-la-ch'i), 40 miles west of K'uei-hua-ch'êng, giving it the name of Cricetulus obscurus. Some specimens of hamsters taken by Mr. Anderson at Tabool were referred to Milne-Edwards' C. obscurus by Mr. Thomas, who considered that this species should be considered as a subspecies of $C$. griseus, under the name of Cricetulus griseus obscurus. This being the case, it is possible that the specimens from IVu-tsai, identified as $C$. griseus, should really be C. g. obscurus. These specimens were in their winter coat, which being very grey seemed to agree more with $C$. griseus from Shantung and Chihli.

Mr. Anderson, when collecting in the present district, found this hamster very common. We found it rather rare, but this may be due 


\section{SPORT AND SCIENCE ON THE}

to the fact that our visit was during a very good year, when, owing to a greater abundance of food, they may have been less tempted to enter our traps. We failed to find their burrows.

26. Phodopus campbelli, Thos.

Two specimens, $\hat{0}$, ㅇ. Tabool, 100 miles

$\mathrm{N}$. of Kalgan, Mongolia. 4,000 ft.

From its general appearance, and the coalescence of the lobes of the foot into one ball, this species certainly ought to be referred to Mr. Miller's new genus Phodopus.

This interesting little hamster was originally described by Mr. Thomas from almost the same district, so that these specimens are practically topotypes. Mr. Anderson found this species also very common, which again was contrary to our experience.

27. Phodopus bedfordia, Thos.

One specimen, $q$. Wu-tsai, 20 miles W. of Ning-wu Fu, Shansi. 6,000 ft. (?)

Judging from the tracks in the sand this little hamster is evidently fairly common in this locality.

Its Chinese name is "Mi-ts'ang "-means "Storer of millet."

28. Microtus angustus, Thos. 


\section{SINO-MONGOLIAN FRONTIER}

\section{Four specimens, 2 추수, 2 우우. Tabool, 100}

miles N. of Kalgan, Mongolia.

This interesting vole, belonging to the "Stenocranius" group, was described by Mr. Thomas from a single specimen taken by Mr. Anderson in this district in 1907. This vole differs from the following species in the extreme narrowness of its skull.

I found them comparatively common, but so voracious that many trapped specimens were completely destroyed by their companions before I could secure them. They seemed to be nocturnal in their habits. Their burrows usually ran just under the earth's surface for a considerable distance, the broken up earth marking their course as in the case of the excavations of moles and mole rats. They appear to live in colonies much as do the gerbils.

29. Microtus mandarinus, M.-Edw.

One specimen, ơ. $\mathbf{5}$ miles S. of T'ai-yüan $\mathrm{Fu}$, Shansi. 2,600 ft.

It has been found impossible to separate this single specimen from $\boldsymbol{M}$. mandarinus, though their localities are so far apart. This is evidently a somewhat rare species in Shansi. It is readily distinguishable from any of the following species by its powerfully built skull. In colour it resembles $\boldsymbol{M}$. johannes. 


\section{SPORT AND SCIENCE ON THE}

30. Microtus johannes, Thos.

Five specimens, $4 \hat{\jmath} \hat{\jmath}, 1$ ‥ Wu-tsai, 20 miles

IV. of Ning-wu Fu, Shansi. 6,000 ft. (?)

The type of this species was described from the mountainous district west of K'o-lan Chow, about 20 miles south-east of the present locality. Owing to their close similarity it was found impossible to separate the specimens from the two different localities, in spite of the fact that one series was taken on a plain and the other on the tops of high mountains.

31. Microtus pullus, Miller.

Two specimens, 1. 0 , 1 ㅇ․ Mountains 50 miles N.W. of T'ai-yüan Fu, Shansi. $5,500 \mathrm{ft}$.

Though in dimensions of body and skull, and in general shape, this vole closely resembles the preceding species, $M$. johannes, its very much darker colour at once renders it distinct. It was described by Mr. Miller as new from specimens taken in the Chiaoch'êng Shan, some 50 miles south of the present locality. It frequents the open glades in the highest mountain regions.

32. Microtus warringtoni, Miller.

Six specimens, 1 o, 5 우우. Tabool, 100 miles

$\mathrm{N}$. of Kalgan, Mongolia. 4,000 ft.

This is a pale-coloured vole, about the same 200 


\section{SINO-MONGOLIAN FRONTIER}

size as $M$. mandarinus, but with a very much smaller skull. The skull is narrower than in either $\boldsymbol{M}$. johannes or $\boldsymbol{M}$. pullus, but not nearly so narrow as in $\boldsymbol{M}$. angustus. Of a lighter colour than $\boldsymbol{M}$. angustus, it has a larger hind foot, though in other body measurements the two are very similar.

While $M$. angustus seems to keep away from camps and buildings, our present species is essentially a camp follower, as we were unable to trap them anywhere except immediately round the house and tents. Unlike $\boldsymbol{M}$. angustus this vole is nocturnal in its habits, usually being trapped during the night.

This interesting species was found to be new and was named by Miller after Mr. Warrington, who first discovered it. ${ }^{1}$

33. Craseomys shanseius, Thos.

Seven specimens, 3 춧, 4 우우. Mountains 50 miles N.W. of T'ai-yüan Fu, Shansi. $5,500 \mathrm{ft}$.

Three specimens, 1 ऽิ, 2 우. Mountains 30 miles IV. of K'uei-hua-ch'êng, N. Shansi. $7,000 \mathrm{ft}$.

This vole, which usually occurs in the forested areas of the Shansi mountains, was first described by Mr. Thomas from specimens taken in the Chiao-ch'êng Shan, west of

${ }^{1}$ Snithsonian Miscellaneous Collections, Vol.60, No. 28. 


\section{SPORT AND SCIENCE ON THE}

T'ai-yüan Fu. Here and further north in the K'o-lan and Ning-wu mountains they are very abundant, especially where there is plenty of moss.

The three specimens from the K'uei-huach'êng district were also found in wooded and mossy localities, though here the timber is less heavy.

This vole is at once distinguishable from any of the foregoing species by its reddish colour.

34. Myospalax fontanus, Thos.

Two specimens, 1 o, 1 ㅇ․ Mountains 50 miles

N.W. of 'T'ai-yüan Fu, Shansi. $6,000 \mathrm{ft}$. Eleven specimens, 2 ㅊำ, 9 우우. Wu-tsai, 20 miles W. of Ning-wu Fu, Shansi. 6,000 ft. (?)

One specimen, $\hat{\sigma}$. Mountains 10 miles $\mathrm{S}$. of Wu-tsai, Shansi. $7,000 \mathrm{ft}$.

Originally identified as $\boldsymbol{M}$. fontanieri, $\mathrm{Mr}$. Thomas subsequently described it as a new species (Ann. Mag. Nat. Hist., January, 1912, p. 93). This species differs from $M$. cansus in the very much more rugged nature of the skull, its greater size, and persistent white spot on the forehead.

It is very common in certain parts of Shansi.

Its Chinese names, "Ha lao," "Hsia lao" and "Ha huei" all refer to its supposed blindness, "Ha" and "Hsia" meaning blind. 


\section{SINO-MONGOLIAN FRONTIER}

35. Allactaga mongolica, Radde.

One specimen, ㅇ. 100 miles W. of Lama Miao, Mongolia. 4,000 ft.

One specimen, ㅇ. Tabool, 100 miles N. of Kalgan, Mongolia. 4,000 ft.

In both specimens the comparative shortness of the ear and hind foot confirm Mr. Miller's distinction between this species and the Kansu allactaga, which he named $A$. mongolica longior. Though common enough in some districts, the Mongolian allactaga is very difficult to secure. The two specimens were caught by us in broad daylight, by riding them down on horseback. The first sought refuge in a short burrow and was easily dug up; the second was chased into a shallow lagoon, which it very nearly succeeded in crossing by repeated jumps. The Mongol name is "Allactahai"; the Chinese name is T'iao-t'u-tzŭ (meaning "jumping hare"'). The Mongols have a superstition that the allactaga sucks the milk of cows, and it is one of the few animals that they will kill on sight.

It is semi-diurnal in its habits, and may be seen skipping about in the twilight or early morning. It refuses to enter a trap or to take any bait.

36. Lepus swinhoei sowerbyc, Hollister.

Two specimens, ठิðَ. Wu-tsai, 20 miles W. of Ning-wu Fu, Shansi. 6,000 ft. (?) 


\section{SPORT AND SCIENCE ON THE}

This new subspecies was named after Mrs. Sowerby by Mr. N. Hollister in the Proc. of the Biological Society of Washington, Vol. XXV, pp. 182-183.

This hare differs from Lepus swinhoei subluteus of the Ordos in having a "greyer rump, lighter pinkish-buff chest-band, and more white on undersides of fore legs," and also in having a larger and heavier skullwith larger audital bullæ. Lepus swinhoei subluteus was distinguished from Lepus swinhoei on account of its paler colour.

These hares were very abundant on the Wu-tsai plain and elsewhere on our line of march. Its Chinese name is " $T$ ' $u$ êrh" or "T'u tzŭ."

37. Lepus tolai, Pallas.

One specimen, $\hat{\delta}$. Tabool, 100 miles N. of Kalgan, Mongolia. 4,000 ft.

In colour this hare seems to be darker than the foregoing species. In North Shansi we sometimes saw extremely light-coloured hares, but were never fortunate enough to secure one, the specimens we shot all being of the usual colouring. These hares are very common, being especially abundant in the long grass round lagoons. As Mongol camps are usually situated in the same localities, it gives one the impression that these much 


\section{SINO-MONGOLIAN FRONTIER}

harassed animals seek the protection of human habitations. This may be the case, as the Mongol watch dogs, while keeping away wolves and foxes, are much too slow to catch a hare. The long grass shelters the latter from their worst enemies, hawks and eagles, which abound in Mongolia.

38. Ochotona bedfordi, Thos.

Two specimens, ô, ㅇ. Tsing-lo Hsien, 30 miles N.W. of 'T'ai-yüan Fu, Shansi. $4,600 \mathrm{ft}$.

One specimen, t. 50 miles N.IV. of 'T'ai-yüan $\mathrm{Fu}$, Shansi. 6,500 ft.

Three specimens, 2 ôt, 1 ㅇ. Wu-tsai, 20 miles W. of Ning-wu Fu, Shansi. 6,000 ft. (?)

All these specimens were taken from within easy distance of Ning-wu $\mathrm{Fu}$, the type locality. This species has also been recorded from North Shensi, but as already stated the Shensi specimens in their winter coats show a paler and less yellow colouring.

Its Chinese name is "Hao-t'u-tzŭ," meaning rat hare, or "Ti-t'u-tzŭ," meaning ground hare $\left(\right.$ Hao $=$ a rat, $\mathbf{T i}=$ ground; $\mathbf{T}^{\prime} \mathbf{u}$-tzŭ $=$ a hare).

39. Ochotona dauurica, Pallas.

Eight specimens, 5 ठే 0 , 3 우우. Tabool, 100 


\section{SPORT AND SCIENCE ON THE}

miles N. of Kalgan, Mongolia. 4,000 ft.

All eight specimens were caught in certain small ravines in the "five hills" from which Tabool gets its name. They seemed to frequent disused badger holes, adding extensive excavations of their own. They are easy to trap with small "gins" placed in the runways; but will not take bait. This is the common Mongolian and Siberian form.

40. Ochotona sorella, Thos.

One specimen, ㅇ. Mountains 50 miles N.W. of T'ai-yüan Fu, Shansi. $\quad 5,500 \mathrm{ft}$.

This is the second specimen recorded of this very rare pika, the type, the only other specimen, having been secured by me from the forests twenty miles north of this locality. It is related to $O$. cansa from Kansu, but is smaller, and darker in colour.

41. Sus sp.

Three specimens, 1 oิ, 2 우오. Mountains 50 miles N.W. of T'ai-yüan Fu, Shansi. $5,500 \mathrm{ft}$.

One specimen, $\hat{o}$ (immature). Wu-tsai, 20 miles W. of Ning-wu Fu, Shansi. 6,000 ft.(?) The last specimen was brought down to the plain from the mountains south-east of Wu-tsai by native hunters.

The species of the Shansi pig has not yet 206 


\section{SINO-MONGOLIAN FRONTIER}

been determined. Much material from all parts of North China will be needed before the status of the North Chinese Suidce can be satisfactorily determined. This seems to be a halfway species between Sus amurensis and Sus moupinensis.

As detailed accounts of the hunting of these pigs appear in Chapter II, further remarks here are not needed. Sufficient to say that recently some very large pigs have been shot in Shansi, where they are on the increase. Districts where pigs were unknown twenty years ago are overrun now. About ten years ago there was an epidemic amongst the wild pigs in Shansi, when hundreds were found dead by the natives. ${ }^{1}$

Its Chinese name is "Yeh chu," meaning "Wild pig," or "Shan chu," meaning "Mountain pig."

42. Cervus canadensis subs.

Two specimens, 1 ô, 1 ㅇ. Mountains 30 miles W. of K'uei-hua-ch'êng, N. Shansi. 7,000 ft. At present it is impossible to identify the subspecies to which this deer belongs. From its habitat it would appear to be related to Cervus canadensis asiaticus of Siberia, or to $C$. canadensis songaricus of the Thian

1 A similar epidemie has taken place this winter (1913-14), so that the pigs have decreased again.-A. de C.S. 


\section{SPORT AND SCIENCE ON THE}

Shan. It seems smaller than the Manchurian wapiti, C. canadensis xanthopygus, a specimen of which I had the opportunity of examining. The habitat of this deer, according to the Chinese, extends right into Turkestan, whence comes the Bactrian wapiti (C. canadensis bactrianus). Having examined horns of this species, and also of $C$. canadensis asiaticus, in comparison with some horns picked up in the same locality as that from which our specimens came, I should not hesitate to pronounce our specimens distinct from either of the others.

Its Chinese name, "Ma lu," means "Horse deer " $(\mathrm{Ma}=$ horse, $\mathrm{lu}=$ deer $)$.

43. Capreolus bedfordi, Thos.

Two skulls, $\hat{\sigma}$, ㅇ․ Mountains 30 miles W. of K'uei-hua-ch'êng, N. Shansi. $7,000 \mathrm{ft}$.

Two skins, Lama Miao, Mongolia. $4,000 \mathrm{ft}$.

The two skins purchased in Lama Miao were said to have been brought from Northern Mongolia. They are very pale indeed, being winter specimens, and are somewhat larger than the usual run of Shansi skins.

The horns of the roe-deer in North Shansi seem to run to an unusually large size. A pair that were secured by a European sportsman were nearly eighteen inches in length and of great thickness. 


\section{SINO-MONGOLIAN FRONTIER}

Some roe-deer shot in North Chihli, east of Kalgan, during a late winter shooting trip in 1912, showed a very pale colour, as compared with Capreolus bedfordi from West Shansi.

The Chinese name is P'ao-tzŭ.

44. Ovis jubata, Peters.

Two complete specimens, 우우. Four skulls,

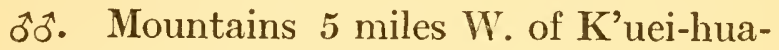
chêng, N. Shansi. $7,000 \mathrm{ft}$.

First described in 1876 from the mountains north of Peking, this sheep has since been pretty much lost sight of. It is probable that it has been steadily killed off, till now it is found in China proper only, in North Shansi, where a few isolated herds still find shelter in the high, barren and precipitous mountains. The most marked characteristic is the increased thickness of the horns in proportion to their length. In this they differ from the other members of the genus Ovis in Asia.

These sheep are difficult to hunt, being extremely shy, besides having wonderful eyesight and sense of smell. Their hearing is also extremely good.

The horns, as already indicated, attain a great thickness. Specimens measured by me ranged from 16 inches to $19 \frac{1}{2}$ inches in 


\section{SPORT AND SCIENCE ON THE}

circumference at the base. The longest horn measured by me was 50 inches.

In winter this sheep has a fine thick coat of a dark grey slate colour, with a brown mane and cream legs. It is very agile and climbs with ease the rocky precipices which occur throughout its haunts.

The mating season is in October and November, the young being born in April, at which time the old rams do not associate with the ewes.

The Chinese name is "P'an-yang" (P'an= a circle, doubtless referring to the shape of the horn ; yang = a sheep).

The Mongol name is "Argali."

45. Gazella subgutturosa.

Three skulls, ỡ $\widehat{0}$. Mongolian Plateau, N. of Kalgan.

Three specimens, 웅․ Mongolia, 70 miles N.N.E. of Kalgan. 4,000 ft.

One specimen, ㅇ. Mongolia, 80 miles N.N.E. of Kalgan. 4,000 ft.

Four specimens, 1 ð, 3 웅․ Tabool, 100 miles N. of Kalgan, Mongolia. $4,000 \mathrm{ft}$.

The three skulls were purchased in the game market in Tientsin, and were said to come from somewhere north of Kalgan.

The other eight specimens were all shot by us during our journey through Inner Mon- 


\section{SINO-MONGOLIAN FRONTIER}

golia, when we saw large herds, sometimes numbering many hundreds of individuals.

The antelopes are very wary, and difficult to approach. Their hearing is good, but is far surpassed by their sight and sense of smell.

The females are hornless, while the horns of the males are not very large, but well shaped and graceful.

This antelope is called the goitred antelope, on account of the enormously distended larynx. The reason for this is not very clear, as the antelope does not seem to possess a voice.

The speed of these antelopes is very great, far exceeding that of the best greyhounds.

The Chinese name is "Huang yang," meaning "Yellow sheep." The Mongol name is "Gurrusu." 

THE FLORA OF THE SINDMONGOLIAN FRONTIER 



\section{CHAPTER IX}

THE FLORA OF THE SINO-MONGOLIAN FRONTIER

$\mathbf{N}$ this chapter, which cannot be considered 1 as more than a very superficial account of the flora of the country along the Chinese frontiers of Mongolia, an attempt is made to give the general reader some idea of the subject.

Notwithstanding the ever-increasing deforestation of the wooded areas, the yearly close cropping of the smaller herbage by the natives and their halfstarved flocks in less favoured districts, the general dryness of the climate over vast stretches of country, and the recurring droughts, sometimes extending over periods of two or three years, there exists a wealth and variety of vegetable forms, the proper identification of which would take a lifetime.

Hitherto only the fringes of the subject have been touched by specialists, and there is very little in the way of works of reference to aid the wouldbe explorer in this vast field of research.

The following notes may therefore be of interest 


\section{SPORT AND SCIENCE ON THE}

to the general reader, at the same time serving as a help to the future botanists of this country, in directing them to the districts, where they may most readily find fruitful fields for their labours.

I have arranged the subject under four headings, Trees, Fruits, Flowers and Cryptogams, discussing under the first, wood-producing, arborial forms; under the second, plants bearing edible fruit; under the third, conspicuous flowering plants, and under the fourth, the flowerless plants such as ferns, mosses and fungi.

\section{i. TREES}

North China is on the whole very poorly supplied with good wood-producing trees. The Chinese have no forestry laws, and though they know good wood when they see it, they do very little in the way of tree culture. Along the main roads saplings are planted from time to time, but the first passer-by, who feels in a destructive mood, or is in need of a stout pole, or even a bit of firewood, cuts down the young tree with impunity. Still many remain and develop into fine trees, but even these are cut down for their wood long before they should be.

The owners of woods round temples in the foothills are very jealous of their preservation, and woe betide the wood stealer who gets caught. This desire to preserve the woods, however, does not prevent the owners from selling every foot of 


\section{SINO-MONGOLIAN FRONTIER}

timber, large or small, if they can get a good price, and as young pines are in continual demand for rafters and small beams in building operations, the young trees are ruthlessly cut down, leaving the once-smiling hillside denuded of spinneys and copses-weary wastes of trampled under-brush, dotted over with stumps, and littered with lopped off branches and bark slivers.

Once while spending a week in the wooded area of Shêng-yeh in the hills west of T'ai-yüan $\mathrm{Fu}$, I made a rough estimate of the number of young pines that were daily being taken out to be sold in T'ai-yüan $\mathrm{Fu}$ for rafters. Two hundred donkeys and mules, carrying on an average thirty sapling pines apiece, passed our camp each day. This had been going on for a month, and would go on for another, so that about three hundred and sixty thousand young trees were cut down in that district alone that summer. There is no reason why the rafters should not have been cut from stout planks of large timber, leaving the young pines to attain a reasonable size before being cut down. This instance serves to show the utter thriftlessness and waste of Nature's resources indulged in by the Chinese in regard to their timber supplies. It is strange that such should be the case with the Chinese, who in other respects get the very most out of the soil they cultivate; but this sad state of affairs must be attributed to bad government, rather than to 


\section{SPORT AND SCIENCE ON THE}

the peasant, whose one concern is to lay by sufficient food and money for the years when his crops fail and starvation threatens him.

The owners of the great forests in the high mountain ranges are even more prodigal in their ravages amongst the trees than the wood-owners of the foothills. With utter disregard for the future, large areas of timber are cut out, and though the planting of new trees would be but a simple matter, nothing is done to replenish the stock. Immense areas of what was, but a few years ago, extensive forest land, now lie bare and brown, with scarcely a vestige of vegetation left. Here again a sad lack of discrimination in the size of the trees cut down is evident. Everything that comes into the way of the woodcutter is hacked down, and if it is too small to be of value is left where it falls.

If North China is poor in trees, Southern Mongolia is absolutely destitute. Only in the Ordos did we see any trees at all, and then they were but stunted willows. The rich grasslands of the Mongolian Plateau we were told were too exposed to the cold blasts from the north for the cultivation of trees, but there must be some varieties which would stand the exposure.

\section{(a) Gymnosperms}

The bulk of the heavy timber in the forests of Western Shansi is composed of conifers, chiefly 218 


\section{SINO-MONGOLIAN FRONTIER}

Spruce (Picea sp.) and Larch (Laryx sp.). These trees occur at altitudes of from 5,000 feet upwards, usually growing on slopes exposed to the north, which, remaining snow-covered all the winter and late into spring, are always more moist than those facing south, where the snow usually melts a few hours after it has fallen. Though these forests are often very extensive, the trees seldom attain a growth of more than two feet in diameter. Large areas of forest, consisting of one or other of these species, is the rule, but not infrequently mixed forests occur.

The lower slopes in these forest areas are often clothed with the Common Pine (Pinus sylvestris), while it is nearly always this tree that goes to make up the woods round temples in the foothills. This tree is prized above either of the foregoing species as a wood producer. The woodcutters strip the saplings of their lower branches, which causes them to grow very tall and straight.

In Shansi one also comes across the peculiar White-barked Pine (Pinus bungeana). It is characterized by having a three-needled leaf, and by its smooth silvery-white bark. This tree is very rare indeed.

In Shensi I came across a small member of the genus Pinus, which grows on rocky cliff surfaces, and is characterized by having five or seven needles. This also seems to be a rare species.

In the foothills and on the plains of Shansi and 


\section{SPORT AND SCIENCE ON THE}

Chihli the Cypress (Cupressus sp.) is very common, being used chiefly to adorn temples and cemeteries. In the wild state it does not attain any great size; but in old temples and official buildings very large specimens may often be seen. The wood of this tree is used in the manufacture of the more expensive coffins, as it is worm-proof and withstands the action of moisture longer than any other kinds.

Mention must be made of the peculiar little conifer which we found growing in small dense patches at long intervals in the Ordos Desert. This resembles the Juniper more than anything else, and as already stated is very resinous.

The Yew (Taxus sp.) occurs very rarely in North China; the vicinity of Shi-t'ieh near T'ai-yüan Fu in Shansi being the only place known to me where it grows. In South Shensi I found it quite abundant in the Tsing-ling Mountains.

Though scarcely a gymnosperm, the peculiar Maidenhair-tree (Ginkgo biloba) should be mentioned next. This, the only living member of a very ancient family, has been preserved in the Buddhist Temples of China and Japan. Though it is thought that wild trees may exist in Western China, none have been discovered so far. There are two very fine specimens in the grounds of the famous old Temple at Chin-ssŭ near 'T'ai-yüan $\mathrm{Fu}$ in Shansi. The Chinese consider the nuts of this tree a delicacy. 


\section{SINO-MONGOLIAN FRONTIER}

(b) Angiosperms

Turning from the gymnosperms we find a great number of trees, comparatively few of which, however, are good wood-producers. In the mountainous regions of Shansi and Kansu, and over the loess hills of Shensi, where uncultivated areas occur, we find such small trees as the Hazel, the Birch, a small variety of Poplar and a stunted Oak growing in great profusion, and forming dense coverts for various kinds of game.

There are several species of Hazel (Corylus), one of which (Corylus heterophylla) is a tall, spare tree, scarcely more than a shrub, with small leaves and a very meagre crop of small nuts. This plant grows as a small tree in sheltered spaces in the heavy timber of Larch and Spruce, or as a thick shrub in dense patches on the more exposed slopes. Another species (C. mandshurica) is a large-leafed shrub, which produces a large nut, sometimes in great profusion. This variety is far less common than the other.

The Birch (Betula sp.), usually occurring at fairly high altitudes, reaches a greater size than the largest Hazel. Its bark readily peels, and is used by the natives in the manufacture of utensils and mats. In the high mountains of Shansi it is particularly abundant. In North Chihli and North Shansi it is often the only tree growing in sparse woods on the northern slopes of the mountains. The trunk seldom reaches a greater dia- 


\section{SPORT AND SCIENCE ON THE}

meter than six or eight inches. Whether this is due to the trees belonging to a small species, or to the fact that the natives are for ever cutting them down for firewood it is impossible to say.

The Poplar (Populus sp.), though very similar to that met with on the plains, never reaches any great size in these mountainous districts. It occurs chiefly in North Shansi, in Shensi and in Kansu, forming the chief growth of any size over large areas of uncultivated land. Except as firewood and in charcoal burning, this tree has very little economic value.

The Stunted, or Scrub-Oak (Quercus sp.) usually occurs on the sunny slopes in the more mountainous regions, showing that it is the severe climate which prevents this tree from developing. It produces a very small acorn, while the stem seldom grows thicker than a man's arm. In the lower hills of Chihli, north, east and west of Peking, the Oak occurs as a fine tall tree.

Besides these trees, which after all are scarcely deserving of the name tree, there are some rarer species, such as the Maple (Acer sp.), the Ash (Fraxinus sp.) and the Aspen (Populus tremula).

On the plains the commonest trees are the Poplar, the Elm and the Willow.

Of these the Poplar (Populus sp.) is most cared for, as it grows very fast, producing a soft wood. It forms an invaluable supply to the Chinese, who use it for all purposes. It is particularly 


\section{SINO-MONGOLIAN FRONTIER}

important to the natives of the country districts and out-of-the-way small towns, where a supply of good wood is wanting. When treated in the same way as the young Pine, this tree grows tall and fairly straight. It is then used for beams and uprights in building operations.

The EIm (Ulmus sp.) is valued for its wood, usually being allowed to grow to a great size before it is cut down. It is grown extensively along the main roads on the plains of Shansi, Chibli and in the valleys of Kansu. The wood being very tough, is used in the manufacture of carts and wheelbarrows, and the better class of furniture.

The Common Villow (Salix sp.) is found all over North China. It was the only tree we saw in the Ordos Desert. All along the banks of the Yellow River and throughout Northern Shensi this tree forms almost the only wood supply, and is usually used in a very unseasoned state. All the barges and ferries on the upper reaches of the Yellow River are made from willow boards, which usually being narrow and crooked, require great ingenuity in being fitted together.

The Weeping Willow (Salyx babylonica) is a tree that pertains more to the towns and well populated districts of North China.

In and round the towns also occur such trees as the Acacia (Robinia sp.) and what the Chinese call Ch'un Hsu. The former is particularly abundant in the cities of Shansi, where it attains an 


\section{SPORT AND SCIENCE ON THE}

enormous size. Old trees of this species are greatly venerated by the natives, and frequently little shrines are built into the hollow trunks, while testimonials, written on red calico, are nailed up all over the trees by suppliants, who have received benefit. This tree casts a delightful shade, and makes a very handsome addition to pleasure grounds. The Chinese also used the wood, though it is soft and not very good.

The Ch'un Hsu, of which the Chinese distinguish two varieties, are soft-wooded, rapid-growing trees. The Ch'ow Ch'un (stinking ch'un), known to science as Aliantus glandulosa, is the smaller variety, and is characterized by a very disagrecable odour, while the Hsiang ch'un (sweet-scented ch'un), known as Cedrela odorata, grows to a large size. The Chinese esteem the tender shoots of the Hsiang ch'un, which they pickle in various ways. These trees seem to be the northern representatives of the Varnish-trees of the south. In South Shensi a variety grows which, if rubbed against, poisons the skin, producing a running eczema that is very hard to cure.

The Sycamore (Acer sp.) is another tree which grows on the plains, and is valued for its wood, which being free from knots is largely used in the manufacture of furniture.

The walnut (Juglans regia sinensis) is also a tree that thrives upon the plains; but it is also cultivated in some of the mountain valleys, 


\section{SINO-MONGOLIAN FRONTIER}

notably in Western Chihli and Eastern Shansi. The nuts produced by some of these are of excellent quality. Needless to say the wood of the Walnut is greatly valued, and is the most expensive to be had in the country. The Walnut occurs throughout all North China, but is very rare in North Shensi.

The Wild Walnut occurs, though rarely, in North China, the mountains round Peking being almost the only place where it is known.

Another nut-bearing tree that should be mentioned is the Chestnut (Castanea sp.) This tree grows wild in the mountainous regions of Northwestern Chihli, occurring only very rarely elsewhere. The chestnut is one of the favourite nuts of the Chinese and it may be seen on every fruit or sweet stall in both town and country.

In the dry and alkali impregnated parts of the Chihli plain and the wide valleys of Shansi the Tamarisk (Tamarix sp.) is to be found. There are two varieties, one a tree with a thick knotty trunk, light feathery foliage and clusters of minute, pink flowers. The whole plant is very graceful and ornamental. It is evidently capable of withstanding considerable drought. The other variety is a small shrub, with a red stem and long, trailing roots. It grows on the mud-flats of the large rivers in Shansi. 


\section{SPORT AND SCIENCE ON THE}

\section{ii. FRUITS}

North China is well favoured in the quality and variety of her fruit-bearing plants. The Chinese are essentially fruit lovers, and will consume enormous quantities when the chance offers.

Though thriftless or ignorant in the matter of tree-culture for wood, they are skilled in the art of fruit culture, being well acquainted with the various methods of grafting, and judicious in selection. In this way some of their favourite fruits, such as peaches and persimmons, have been brought to a high state of perfection.

On the whole the fruit of this country resembles that of Europe ; but there are some very characteristic kinds.

The commonest, and perhaps most characteristic of the fruit-bearing trees of the country on the south side of the Great Wall is the Jujube (Zizyphus sativa) or "Tsao." In and round every village and town on the plains and in the lower foothills of Chihli, Shansi and Shensi numbers of these trees may be seen. They are especially abundant in Western Chihli, on the plains of T'ai-yüan Fu and Hsin-Chou in Shansi, along the banks of the Yellow River from He-K'ou to T'ung-kuan, and up all the tributaries of that river in Shensi and Shansi. In Shantung also the Jujube is extensively cultivated, many specialized varieties being grown there; but this province scarcely comes under our title. 
PLATE X̃V.

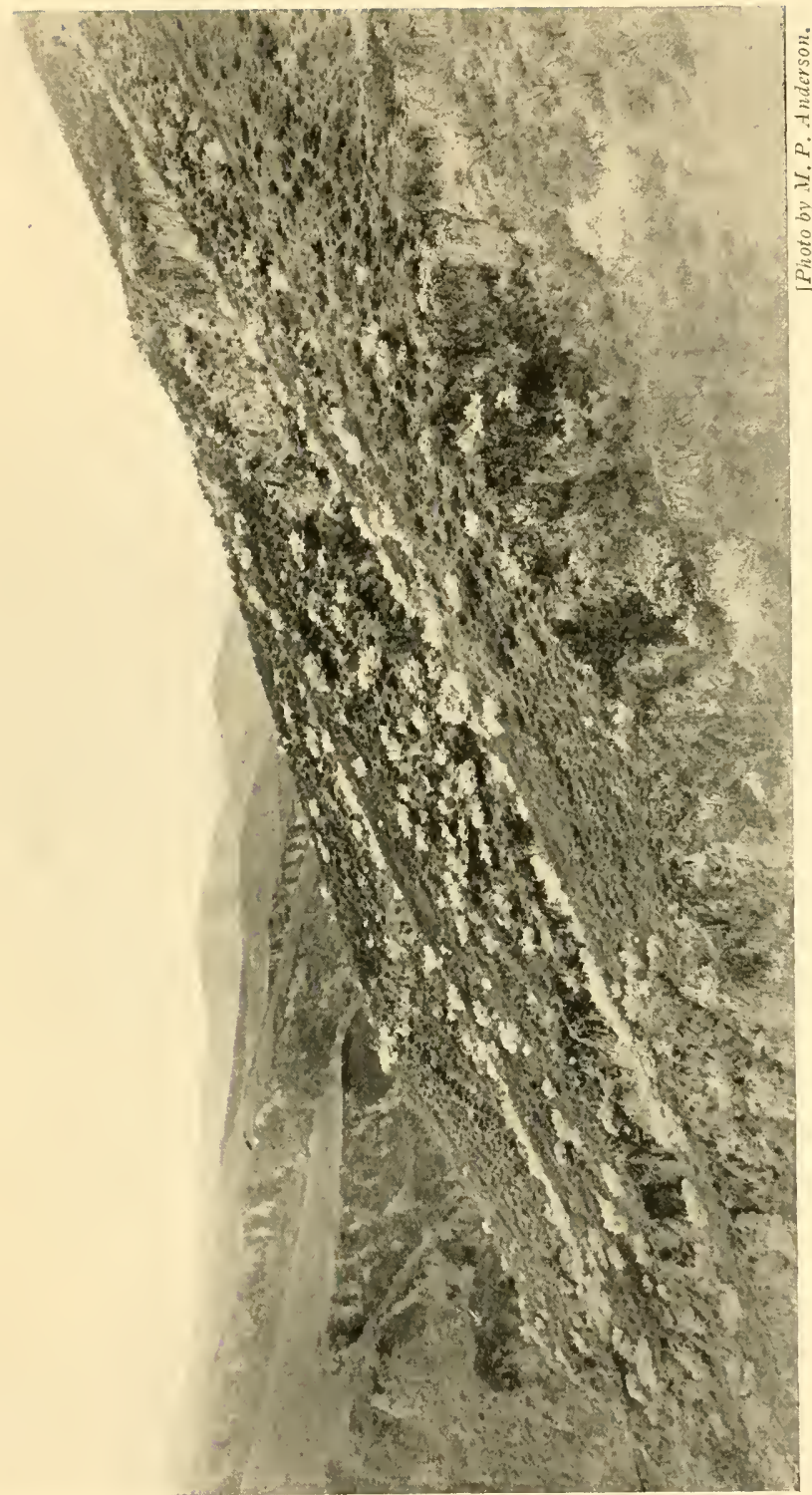

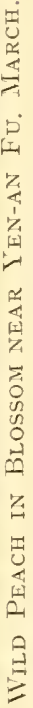





\section{SINO-MONGOLIAN FRONTIER}

The cultivated Jujube tree produces a great abundance of fruit, which when green resembles in appearance nothing so much as the olive. When ripe the fruit is very palatable and is of a rich red-brown colour. It does not decay, but dries easily, and so can be conveniently kept for long periods, or transported over great distances. The fruit is greatly esteemed by the Chinese, who use it extensively in their confectionery, and by soaking it in honcy, make an excellent preserve. These honey dates are shipped to Southern China in great quantities.

There are several varieties of Jujube, the differences lying in the shape, size, substance and sweetness of the fruit. A stoneless variety is grown in the Wu-hu Magistracy of Shantung, near Laoling. Of a sweet taste and good flavour this Jujube is greatly esteemed, and was annually sent to the Manchu Court at Peking.

The wood of the Jujube is excessively hard. In colour it is red alternating with light yellow, so that it is very ornamental. In certain parts of the country the natives make rolling pins, toys, and other articles of domestic use.

The tree itself is tall and straggling, with long, usually twisted and bent bole. The leaves are pinnate, of a light-green colour and glossy surface. The flowers are small and green.

Long after all other trees are in leaf the Jujube remains naked and brown. The first shoots do 


\section{SPORT AND SCIENCE ON THE}

not appear till towards the end of May. The fruit does not ripen till the end of September.

The Wild Jujube (Zizyphus sativa spinosa), as it grows exposed to continual cropping and burning by the farmers, is nothing more than a shrub, but when left alone it attains the size of a small tree. The fruit of the wild plant is very small, with a large stone, and has a pleasant sour taste. The country people grind it up and make it into a sort of cake, very dry and powdery. The stem and branches of this plant are covered with long spines, some of which are straight and others hooked like an animal's claw. It is thus extremely useful in hedge-making. Usually the Vild Jujube grows in dense thickets over grave patches, and as already stated, forms fine cover for pheasants and other small game. Like the cultivated variety, it comes into leaf very late in the season.

Neither the Wild nor Cultivated Jujubes will grow at altitudes over 3,000 feet above sea level.

There is a second subspecies of this plant recognized, which, owing to its gnarled and twisted branches and hooked spines, has been called the Dragon's-claw Jujube (Z. s. tortuosa). This plant is used as an ornamental shrub.

Another fruit-bearing tree, characteristic of the country, is the Persimmon (Diospyros). Though the majority of species or varieties belonging to this genus belong to Central China, yet a few 


\section{SINO-MONGOLIAN FRONTIER}

occur as far north as Peking, and so may be mentioned here.

In the wild state the Persimmon is rather rare, occurring in Chihli round Ch'ang-li-Hsien on the Peking-Moukden Railway, not far from the sea coast, and also in the mountains west of Pao-ting Fu. This plant, known as Diospyros lotus, produces a small yellow fruit, which nevertheless has a good flavour. This wild form is used as a stock, upon which the cultivated varieties are grafted.

Another wild form, which occurs in Shansi and Shensi, produces a very small black fruit with large stones or pips. This is called by the Chinese "He tsao," meaning "black jujube."

Of the cultivated varieties the largest and most prized is known as the "Ta mo pan "Persimmon. This is a fine golden-orange coloured fruit, practically seedless, and of a sweet flavour. It is nonastringent, a much to be desired quality in Persimmons. There are numerous other smaller varieties, of which one occurs in the mountains along the border line between Shansi and Chihli. A very sweet red Persimmon grows in Honan and South Shensi.

The Chinese dry the fruit of the Persimmon, which is then very pleasant and wholesome to eat. The best dried fruit comes from Pei-t'ung-kuan, just north of the Wei Valley in Shensi.

Throughout the mountainous regions of all the northern provinces the Wild Peach (Amygdalus 


\section{SPORT AND SCIENCE ON THE}

davidiana) grows, often in great profusion. In Shensi I have seen it growing so thickly that when in bloom it gave the impression of snow on the distant hillside.

As already stated, this is believed by some to be the original Wild Peach, from which all our numerous varieties have been developed. As Wild Peaches also occur in India and Persia, it cannot be taken for granted that the Chinese form is the original stock.

It is a very hardy plant, and makes a good stock, upon which to graft the cultivated varieties. The fruit is small and sour, with hard leathery flesh. The blossom, which varies from pink to white, is very fine, so that as an ornamental shrub this plant is greatly valued. When cultivated there is an even greater variation in the colouring of the blossom, while the plant will attain a considerable growth, developing into a tree. The kernels, as well as the fruit, form one of the staple diets of the squirrels and chipmunks in the districts where the Wild Peach grows. The stones, being round and ornamental, are often used by priests as rosary beads or by children in a game resembling our "knuckle bones."

There are several varieties of the Cultivated Peach (Amygdalus persica), in the development of which the Chinese have been most successful. The fruit of some varieties attain an enormous size, being said to weigh as much as one catty 


\section{SINO-MONGOLIAN FRON'TIER}

( $1 \frac{1}{3}$ Ib.) apiece. In Shansi some small green peaches of an exquisite flavour are cultivated. There is another variety with deep crimson-coloured flesh.

Recent expcriments carried out in America show that the Peaches introduced from China do far better than those from Europe. This fact is believed to be due to the greater drought-resisting qualities of the Chinese plants.

The Wild Apricot (Prunus armeniaca) also flourishes in the mountains of North China. Unlike that of the Wild Peach, the fruit is soft, sweet and juicy. It grows into a good-sized tree, in which characteristic it again differs from the Wild Peach.

The Apricot is extensively cultivated by the Chinese, and many large and delicious varieties are grown. The fruit is dried for winter use, while the kernels are exported under the name of Almonds. In the mountains of Shansi the natives extract oil from the kernels, which they use in their lamps.

The Wild Plum (Prunus sp.), already referred to in an earlier chapter as the blackthorn, occurs, though somewhat rarely, in the mountains of Shansi. It sometimes attains the size of a large shrub. The fruit is small, black and very sour. There are several varieties of cultivated Plums, a small purple one being the most common. Large yellow plums may also be bought occasionally.

In North China only two varieties of Cherries 


\section{SPORT AND SCIENCE ON THE}

occur, both of which are wild. One, the Bush Cherry (Prunus tomentosa), produces a small red fruit, obtainable only during a very short period in the month of June. The fruit is scarcely worth the trouble of stoning. The Cherry grows in the form of a dense shrub in dry rocky ravines.

In the coastal regions of North-eastern Chihli a very small bush grows, which bears a large and delicious cherry. When fully ripe this fruit is of a deep crimson colour, and is equal in flavour to any of our home varieties. The bush seldom reaches a height of even one foot, being found low down in the thick grass on the hillsides. The stem is short, twisted and woody; the leaves are large. Each plant produces two or three clusters of fruit, which, unlike those of the Bush Cherry, grows on a long peduncle. I have been unable to find any reference to this very remarkable Cherry.

The Pear (Pyrus) is represented in North China by several wild species, as well as by a number of cultivated varieties.

The commonest wild form, and the one from which the Chinese cultivated varieties have been developed, is Pyrus chinensis. This tree grows in the valleys of the mountainous districts. It is a tall tree, not very common, with a very small fruit. I have found this species growing on the tops of the loess ridges both in Shansi and Shensi.

A second species grows upon the plains, producing 


\section{SINO-MONGOLIAN FRONTIER}

a small soft fruit, while a third grows in the foothills and on the plains.

There are a number of cultivated Pears in China, belonging to three pronounced types. The commonest of these is characterized by very yellow skin, hard, white, somewhat granular flesh, with no very special flavour. It is juicy and refreshing, but very few Europeans like it. The finest variety, known as Ya-li, comes from Kuo-Hsien in North Shansi, in which district several other well known varieties are cultivated.

Another type of Pear is the Pai li, which is small with a pale yellow skin and a soft white flesh of a distinct though delicate flavour. This variety is grown round Peking, and is often called the Peking Pear.

The third type has a dark yellow-brown skin, with very soft, granular, juicy flesh. In flavour this Pear resembles more closely the European varieties, though it is much inferior to them. It is supposed to have been developed from the second mentioned species of Wild Pear.

A Crab-apple (Malus baccata) is to be found in the northern provinces of China, though it is by no means common. The fruit is very small, though of a good flavour.

China is very poor in cultivated Apples, only very inferior varieties being grown. Of these the P'ing-kuo is most esteemed by the Chinese. This is a large Apple with a pale green skin and 


\section{SPORT AND SCIENCE ON THE}

white pithy flesh. The flavour is very delicate, without the least acidity. A cultivated Crabapple also exists, which in flavour far surpasses the P'ing-kuo. A third variety of Apple also occurs, the fruit of which is of a medium size with dark red skin, mealy flesh, and sour taste.

A fruit that is much valued by the Chinese is the Edible Haw (Crataegus pinnatifida). In a wild state the fruit is small and very sour, but when cultivated it reaches the size of a small medlar, and though sour is very palatable. It makes up into a fine jelly.

Already I have mentioned the Grape as being extensively cultivated in the Chiao-chêng and Wên-sui districts of Shansi. Though this is undoubtedly the finest grape-producing area, this fruit is also cultivated all over North China, right up to Kalgan in North Chihli. At Hsüan-hua Fu, near Kalgan, a very fine quality of White Grape is grown.

Though the Wild Grape (Vitis amurensis) occurs in North China, it is by no means common.

Pomegranates and Figs are cultivated in gardens in North China, but are not indigenous and do not grow wild.

In the mountains of Shansi several kinds of edible berries are to be found. The most abundant of these is the Gooseberry (Ribes sp.), thick bushes of which grow in the Ning-wu districts in every valley and ravine. Both the fruit, which 


\section{SINO-MONGOLIAN FRONTIER}

attains the size of a marble and is very luscious and sweet when ripe, and the stems are thickly covered with sharp spines. Sometimes bushes of spineless fruit may be found, and they are very nice. Even the spiny fruit can be eaten if a little care be exercised. It is strange that the Chinese have never thought of cultivating this excellent berry.

In the higher parts of the mountains two varieties of Red-currants occur. One of these is a tall thickly leaved and close-growing shrub, the berries, sharp and astringent, growing in a thick cluster on an upright stalk. The other resembles exactly the Red-currant of British gardens, both in appearance and flavour.

A very superior Wild Raspberry (Rubus idaeus) also occurs in these mountains. It, too, resembles the British cultivated variety, and grows chiefly in the valley bottoms, where one may sometimes find extensive patches of it. The fruit is fully as large as our garden variety and is very sweet and well flavoured.

Another berry belonging to the genus Rubus grows on the mountain sides. This resembles the Dewberry, in leaf and blossom, and in its straggling growth. The fruit, however, remains of a bright red colour when ripe, one or two only of the drupels remaining, which attain a comparatively large size.

In the long grass and open glades of the forests 


\section{SPORT AND SCIENCE ON THE}

the Wild Strawberry (Fragaria sp.) thrives, producing two or three large berries upon each stalk. The latter are unusually long, which is doubtless due to the length of the grass in which the plant grows. The flavour of this fruit is excellent. I found it growing at altitudes exceeding 8,000 feet.

There are at least two species or varieties of Mulberry (Morus). One of these (Morus alba) bears a white fruit of a very fine flavour and large size. It grows in the province of Chihli. I have not seen it in Shansi or Shensi, but it doubtless occurs there. The other variety produces a fine purple fruit, which is perhaps of a stronger flavour than the white. This plant sometimes attains the size of a large tree, and on account of its large leaves gives good shade. This Mulberry is extensively cultivated in both Shansi and Shensi, chiefly for the sake of its leaves, upon which silkworms are fed.

In the mountains of North China there grows in great profusion a very thorny shrub, with pale blue-green leaves. It produces great quantities of a very sour, orange berry, which, however, has an exquisite flavour. The berries grow in close masses upon the stem. They are no larger than small peas, have several small hard pips, are very soft and juicy, and grow upon short petioles. They form one of the staple winter diets of the pheasants, these birds always being found in coverts of this shrub. 


\section{SINO-MONGOLIAN FRONTIER}

The Chinese, like the Negroes of America, are exceedingly fond of Melons, of which they have a number of cultivated varieties. First and foremost comes the Water-melon. These are grown very extensively, where the soil and climate are favourable, and in summer the Chinese consume enormous quantities of this harmless fruit. A European, who attempted to start a mineral water factory in T'ai-yüan Fu, found in the Water-melon an unconquerable competitor, and finally was forced to abandon the enterprise.

Besides the Water-melon there is a long soft White Melon, with a delicate flavour known as "Ts'ai kua" (Vegetable Melon), also small orange and green Melons, known respectively as T'ien kua (Sweet Melon) and Hsiang kua (Scented Melon).

Pumpkins of various kinds also occur, chief amongst which are Cucurbita maxima, C. moschata and C. pepo. The Cucumber, though scarcely a fruit, is also extensively grown. None of these Melons or Pumpkins are found in a wild state.

\section{iii. FLOWERS}

Under this heading comes so vast an array of plants, that it is impossible to do them even the barest justice in a portion of a chapter. I must be content with a mere skimming of the surface, mentioning a few of the more important Orders, and the chief representatives of each.

In many places the mountains of Shansi and 


\section{SPORT AND SCIENCE ON THE}

Shensi, and even those of districts originally included in Mongolia, are clothed with bushes of a Wild Rose. In spring these are thickly covered with fine yellow blossoms, making a wonderful display of colour. The red stem of this Rose is thickly covered with sharp spines. The leaves are very small and pinnate. In autumn the bushes are thickly laden with round hips of a dark crimson colour and sweet pleasant taste. Altogether this is one of the most beautiful wild flowering plants of North China, and should be introduced into European gardens. I found this plant growing on the very border of the Ordos Desert on dry and exposed mountain sides.

Another Wild Rose of a straggling growth and with a large pink blossom occurs in the mountains of Shansi, usually being found in the sheltered ravines, while a third species of stunted growth and with a small pink blossom occurs in the mountains of North Chihli and North Shansi, and even in the hills of the Mongolian Plateau.

A fine flowering shrub which is found in the mountainous regions is the Lilac (Syringa sp.). It grows to a height of from three to eight feet, and is thickly covered with fragrant blossoms. The Chinese have fine cultivated varieties of this species.

The Privet (Ligustrum sp.) is another flowering shrub, which occurs in these mountains, though it is less common.

The Order Compositæ is well represented in 238 
PLATE XVI

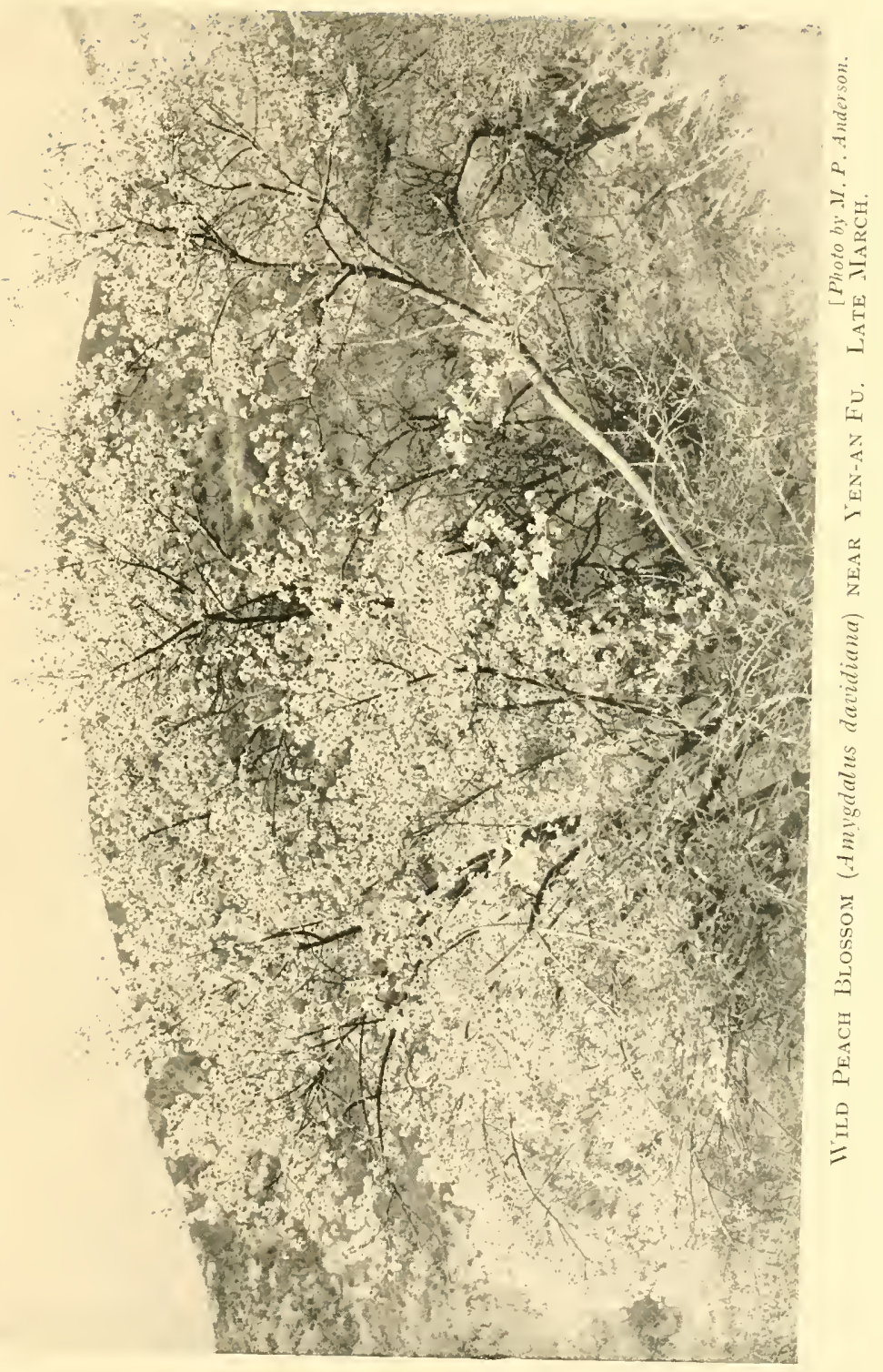





\section{SINO-MONGOLIAN FRONTIER}

North China, and also in the more fertile parts of Inner Mongolia. Daisies and Marguerites of all kinds occur, besides the Dandelion, Thistles of various kinds, the Burdock, the Sawwort, the Starwort, the Nipplewort, the Yarrow, Marigolds, Wild Chrysanthemums, and a number of species with inconspicuous flowers and strong scented leaves, which evidently belong to the same family as the Cudweed (Gnapholium) of our English marshes and fens. In the mountains of Shansi a large pink Daisy, which flowers in autumn, is very common, while the Michaelmas Daisy is also abundant.

The Leguminosæ are also well represented, Trefoils, Vetches and Clovers occurring in great variety in Mongolia, as well as in China proper. The Sanfoin also occurs, besides some varieties of leguminous shrub with fine pink blossoms. In the Chiao-ch'êng Shan of Western Shansi we encountered large patches of a small leguminous shrub with yellow blossoms and very formidable spines. Along the edges of the Ordos another spiny shrub belonging to this order forms almost the only herbage.

Labiates are less common, though in this connexion it is interesting to note that, just as in Great Britain the Stinging Nettle (Urlica) is imitated in appearance by the Dead Nettle (Lamium), so in China the Stinging Nettle, which has a deeply lobed palmate leaf, is imitated by a 


\section{SPORT AND SCIENCE ON THE}

Dead Nettle. The two plants grow in the same localities and by the careless observer might easily be taken for the same thing. This Dead Nettle has a large pink flower. Both plants are common on the Mongolian grasslands north of Kalgan, as well as all over North China.

Several other Labiates are to be met with, one variety of which, bearing a fine purple-blue flower, is very conspicuous. Wild Thyme is very abundant in North Shansi.

In the mountains of Shansi, Shensi and North Chihli a species of Japanese Anemone (Anemone $s p$.) is very common. White, pink and even mauve blooms are met with, though the last are not common. There are several other species of Anemones, notably a fine blue variety, a pink one and a small white one resembling the British Wood Anemone.

Buttercups and Celandines are also common. A fine variety of Marsh Marigold was noticed in some of the swampy valleys near Lama Miao in Mongolia, while in the permanent streams of North China I have frequently found the Bulbous Crowfoot and the Water Ranunculus.

In Kansu a fine Wild Peony grows, sometimes in great profusion. This is not the shrub or tree variety, which as far as I know has not yet been discovered in a wild state, though Shensi is supposed to be its original home.

On the plains and in the lower hills there are 


\section{SINO-MONGOLIAN FRONTIER}

several species of Clematis, none of which, however, have very conspicuous blooms. One, found in Shansi, has clusters of small, white, bell-shaped flowers. Another has a yellow blossom, while white and purple varieties occur.

Primulas are very few in North China. There is one species, which grows along the dusty roadsides in Shansi. This resembles the Cowslip, but is larger and of a deep crimson-brown colour.

In the mountains west of K'uei-hua-ch'êng in North Shansi I found a single specimen of a light mauve-coloured Primula growing in the shade of some small timber. These are the only two members of this Order which have come to my notice.

The Forget-me-not and Scorpion-grass (Myotis) are fairly common in Shansi, though members of this Order are not numerous.

The White, the Scented and the Common Violet all occur, in some places in great abundance. In North Shansi, pink blossoms are also not uncommon. In the woods a small Pansy may sometimes be found, though it is rather rare.

The Order Campanulaceæ is represented by the Harebell, the Canterbury-bell and the Bellflower, all of which are very common in the mountains of Shansi, where also and in Mongolia the Scabeus (Knautia sp.) is very abundant.

The Honeysuckle (Lonicera sp.) and the Elder 


\section{SPORT AND SCIENCE ON THE}

(Sambucus sp.) represent the Order Caprifoliaceæ. These plants are not very common, however.

Caryophyllaceæ is represented by several varieties of Campion, the commonest of which is the Ragged Robin.

The Field Convolvulus (Convolvulus sp.) occurs in great abundance, though a large white member of the same family is less common.

A Stonecrop and a small narrow-leaved Houseleek seem to be the only representatives of the Crassulaceæ.

In members of the Order Scrophulariacer, North China seems to be rather poor, and South Mongolia entirely wanting. The Toadflax and a species of Foxglove are the only common varieties. The Sesamon is extensively cultivated in certain parts, the seed being exported in great quantities.

Wild members of the Poppy family are very rare, a variety of Horned Poppy and a small red Poppy being the only ones I have hitherto come across. The Cultivated Poppy, from which opium is obtained, was up till recently grown all over North China, wherever the soil was suitable.

The Geraniaceæ are represented by several small varieties of the Crane's-bill type.

The Broad-leaved Plantain is very common, especially in damp localities.

One of the most striking flowers of the Shansi mountains is the Gentian, which blooms all through the summer. The blue colour of this 


\section{SINO-MONGOLIAN FRONTIER}

beautiful plant surpasses in intensity that of any other blue flower of these parts. This plant usually grows on dry, bare spaces, seeming to thrive better when absolutely free from other plants. The Rock Rose (Helianthemum) is another of the mountain flowers.

Several varieties of Dock occur, in which connexion one must mention the Wild Rhubarb. This grows very extensively in the mountains of North Shansi and Chihli, and is also abundant in the low hills of Inner Mongolia. It is of an excellent flavour. The natives have discovered the medicinal properties of its roots.

In all the northern provinces the Mistletoe is found, growing chiefly on the Elm and the Poplar. The peculiarity of the Chinese Mistletoe is that the berries, instead of being white, are a brilliant red or yellow, which make it very ornamental.

In Monocotyledonous plants North China is not over abundant.

Several varieties of Iris occur, the commonest of which is the Flag. This plant grows in tufts all over North China and is one of the commonest plants in the grasslands of Inner Mongolia. A small but strikingly beautiful Iris occurs in North Shansi in the mountains round K'uei-hua-ch'êng. This flower ranges from deep purple to pink in colour and is beautifully marked. A tall, thinstemmed, narrow-leaved, small-blossomed variety occur's, though somewhat sparsely, from the sea 


\section{SPORT AND SCIENCE ON THE}

coast in North-eastern Chihli to the western border of Kansu.

There are two or three Wild Lilies in North China, though the Chinese have a great variety of cultivated forms. In the mountains of Shansi, Shensi and Kansu and in North Chihli a beautiful Scarlet Lily is very abundant, a tall Yellow Lily being met with on the plains and lower mountain sides. The latter also occurs in Mongolia. In. the Ning-wu and K'o-lan Chow districts of Shansi, and even as far north as K'uei-hua-ch'êng, I have seen the Solomon's Seal growing plentifully.

Three varieties of Orchis occur in North China though they are far from common. One, which closely resembles the Spotted Orchis, is found in the marshes near the sea coast of North-east Chihli. The other two occur in the lower mountains of Shansi. One of these has a small green flower growing on a spike, and resembling that of the Tway-blade: the other has a small pink and white flower. Both plants are very small, and, growing in the deep grass, are not easily found.

There seems to be no Wild Daffodil or Narcissus, though the well known Chinese Sacred Lily is cultivated everywhere.

Several varieties of Wild Garlic occur, and I have also found a Wild Leek, and a Wild Onion.

Every variety of grass is to be found. In certain places the tall Reed, from which the Chinese 


\section{SINO-MONGOLIAN FRONTIER}

make mats, grows in dense jungle-like patches, while in the river valleys and streams Sedges and Bulrushes form cover for wild-fowl. The furthest north that the Bamboo grows wild is in the Tsingling mountains of South Shensi, but in gardens it is found as far north as Tientsin.

The Chinese cultivate a number of cereals, the chief of which are, Millet, Sorghum, Rice, Wheat, Maize and Oats. The last being able to withstand severe weather, is grown high up in the mountain ranges of Shansi, and, with the Potato, forms the staple diet of the mountaineers. This cereal and also Wheat, with a little Millet, is now being grown by Chinese on the Mongolian Plateau with great success.

\section{iv. CRYPTOGAMS}

Under this our last heading we have to consider but few plants.

North China is extremely poor in ferns, only six species having come under my notice, in spite of my continual searching for these types of plants. This scarcity is doubtless due to the dryness of the climate.

One of the commonest ferns is a small plant with a frond, shaped like a deeply lobed vine or maple leaf, and a thin black stalk. The spores grow along the margins of the frond on the under surface. This fern grows in the lower mountains 


\section{SPORT AND SCIENCE ON THE}

of Shansi, in the crevices of old temples and walls, and in well shaded ravine bottoms.

Two other small ferns may also be met with in the same spots. One resembles the Hart's Tongue, though it is of a very minute size. The frond is more tapering, ending in a long threadlike point, at the very tip of which the spores occur. When this tip touches the ground, the spores develop and a new plant grows. In this way this little fern propagates itself. The other variety more resembles our Spleenwort, though it also is very small, and not over abundant.

In the crevices of some rocks in the highest mountains of Western Shansi I found a delicate fern, also resembling the Hart's Tongue in shape, though without the long point of the species already described, nor the auriculate base of either.

In the mountains of North Shansi and Chihli yet another fern with a lanceolate frond occurs. This variety is more common than any of those already mentioned, and usually grows upon rock surfaces, even in exposed positions. The under surface of the frond is thickly covered with spores. In the dry season the frond curls up, exposing the spore-covered under surface, so that they are readily scattered by the wind.

The remaining species of fern is the Bracken, which grows extensively on some of the warmer slopes of the mountains of Northern and Western Shansi and in Kansu. Except in its smaller size 


\section{SINO-MONGOLIAN FRONTIER}

this fern exactly resembles the European species.

Other Cryptogams prevalent in North China are the Horsetail (Equisetum), the Liverwort (Pellia) and the Selaginella (Selaginella sp.).

Of the last named there are two species. One, resembling the Common British species (S. spinosa), grows in damp ravines in the mountains of Shansi. The other, a drought-resisting form, grows on exposed rock surfaces in the barren Limestone mountains bordering the Chihli plain.

Numerous mosses and lichens grow in the forests and mountainous areas.

In conclusion I would mention the fungi, many edible species of which exist. The Mushroom is very common, especially upon the Mongolian Plateau. It is surprising how many species belonging to this genus are eaten by the Chinese, who dry them for winter use, and serve them up at feasts in a great many ways. The poor people in the mountains of Shansi yearly make quite a good income by drying and selling the various kinds of edible fungi, some of the choicer varieties fetching as much as 500 cash (over 1s.) per pound. 

GEOLOGICAL NOTES 



\section{CHAPTER X}

\section{GEOLOGICAL NOTES}

CEOLOGICALLY the country traversed on the various journeys described in this book may be divided into two sections, separated roughly one from the other by the outer loop of the Great Wall.

South of this line, in Chihli and Shansi, the outcrops are chiefly of sedimentary rocks, with here and there masses of the underlying plutonic and metamorphic rocks showing through. Thanks to Baron von Richthofen and Bailey Willis these rocks are pretty well understood, and there remains only the work of recording their occurrence in different localities, and any other geological phenomena hitherto unobserved. These stratified rocks extend westward and northward across the Ordos, North Shensi and well into Kansu, and also up to the extreme north-west of Shansi.

North of the outer loop of the Wall the outcrops are entirely igneous and metamorphic, granite, trachyte, basalt, porphyry, gneiss and schist occurring in great confusion, so that considerable 


\section{SPORT AND SCIENCE ON THE}

time, much close study and hard work will be required to reduce them to a system. There is evidence of great volcanic disturbance all along, and northward of this border line.

Nowhere are the sedimentary rocks visible, except well to the east of the eastern extremity of the loop, and far to the north-west of its western extremity.

This chapter is divided into nine parts, each dealing with a different section of country. The first four include the sedimentary formations which lie south of the outer loop of the Wall; while of the others, four consist of notes upon the igneous and metamorphic rocks just mentioned, and one (Part 8) deals with the recurrence of the sedimentary rocks in and west of North-western Shansi.

The parts are as follows :-

Part 1. The geology of the country traversed by the Chên-T'ai Railway: Western Chihli and Eastern Shansi.

Part 2. The geology of the country traversed by Anderson and the author in 1908: Northern Shensi, the Ordos, and Western Shansi.

Part 3. The geology of the Upper Fên Ho basin Western Shansi.

Part 4. The geology of the country traversed by the Peking-Kalgan Railway, North Chihli. 


\section{SINO-MONGOLIAN FRONTIER}

Part 5. The geology of the Ch'ing Ho and Hsiwan-tzŭ district, North Chihli.

Part 6. The geology of the country traversed by the Chang-sui Extension Line: Northwestern Chihli and North-eastern Shansi.

Part 7. The geology of the country from Yangkao to K'uei-hua-ch'êng, North Shansi. Part 8. The sedimentary rocks, north-west of Pi-ch'ien-ch'i, North-western Shansi. Part 9. The geology of the Mongolian Plateau, Inner Mongolia.

\section{PART I}

The Geology of the Country traversed by the Chên-T'ai Railway: Western Chinli and Eastern Shansi

This section of country contains one of the most extensive and important coalfields in China, and therefore deserves closer attention than the writer has been able to give it. The following notes have been gathered during several journeys by rail between Shih-chia-chuang and T'ai-yüan $\mathrm{Fu}$, so that the conclusions drawn therefrom can only be considered as tentative and not final. It is hoped, however, that they will be of value, as this district has not been too thoroughly explored or described.

Richthofen traversed this area before any railway 


\section{SPORT AND SCIENCE ON THE}

was even contemplated, and described the coalfields and iron-mines in glowing terms. Subsequently his descriptions were revised and annotated by the late Rev. Herbert Dixon, of Shansi, for the Pekin Syndicate. Further investigations and reports were made for the Syndicate by their engineer, Mr. J. G. H. Glass. Nevertheless there yet remains much to be done in the geology of the district, as the last two explorers confined their attentions chiefly to its mineral resources.

The journey should be very instructive to any one wishing to study the geology of Shansi, for, owing to the general westerly dip of the strata, one passes through the whole series of the sedimentary rocks, from the Hu-t'o series (pre-Cambrian limestones, etc.), through the Sinian system (Cambro-Ordovician limestones, etc.), through the entire Shansi formation (shale and sandstone coal measures and overlying red sandstones of the Red Beds) to the Huang-t'u formation (loess and other quaternary deposits).

On leaving Shih-chiah-chuang, the junction of the Chên-'T'ai and Pe-Han Railways, one soon passes from the great alluvial plains of Chihli into rugged mountains, which are composed of the dark massive siliceous limestone belonging to the Hu-t'o or Nank'ou series. ${ }^{1}$

1 This limestone occurs also in the Wu-t'ai Hsien district of Shansi, besides forming a large mass of the mountains at the famous Nank'ou pass north of Peking, at which point 


\section{SINO-MONGOLIAN FRONTIER}

The slopes facing the plain (i.e. eastward) are in the form of a steep and rugged escarpment, formed, possibly, by extensive erosions, but more probably by a fault running roughly north and south, with the downthrow on the east. This theory may be supported by the fact that the strata, which are very marked, dip to the west at varying angles. Slight folding is also noticeable.

After passing westward through the Hu-t'o series for a short distance, one encounters typical Sinian limestones, which are next replaced by sandstones of the Shansi coal measures. Here, at a point just before Ching-hsing Hsien is reached, a good quality of bituminous coal is extensively mined by the Ching Hsing Mining Company.

Immediately west of Ching-hsing Hsien, massive limestone mountains are again encountered, suggesting the existence of another fault, especially as the eastern slopes again present rugged escarpments, and the strata still dip to the west. As far as could be judged from the train, this limestone extends all the way to the P'ing-ting Chou district. This does not agree exactly with Richthofen's map, which gives alternating outcrops of limestone and coal measures, but it must be remembered that the railway line follows the valley bottoms,

it was described and named "Untersinisch" by Richthofen. This was subsequently divided from the Sinian system by the members of the Carnegie Expedition, 1904, who discovered the unconformity between the two systems. 


\section{SPORT AND SCIENCE ON THE}

deep down in the strata, so that one cannot observe from it the outcrops at higher altitudes in the mountains, while Richthofen, travelling by road, actually crossed several high ridges, and therefore was able to observe the topmost outcrops.

Just before reaching Yang-ts'uen, the station for P'ing-ting Chou, one comes to the end of the limestone, and encounters once more the famous Shansi formation, with its extensive beds of coal and iron.

My friend, Professor E. T. Nyström, formerly of the Shansi Imperial University, has dealt very fully and ably in his book, The Coal and Mineral Resources of Shansi Province, China, with the coal of this district, besides that of nearly all the other known sources in the province. I might just mention that the coal is of a very good quality, and that iron ore is very abundant and easily worked, though at present little is being done to develop any industries connected with these valuable mineral resources.

Professor Nyström in his book gives amongst others the following analysis of the anthracite coal of this district:-

Moisture . . . 0446 per cent.

Volatile Hydrocarbons $6 \cdot 12$,

Fixed Carbon . . $85 \cdot 80$,

Ash . . . $7 \cdot 62$,

Sulphur . . . $0.89 \quad$, 


\section{SINO-MONGOLIAN FRONTIER}

Referring to his various analyses he says : "All these analysis of coal from P.T.C. (P'ing-ting Chou) show a coal of high quality. Richthofen calls it equal to the best Pennsylvanian anthracite."

As one travels up the valley from Yang-ts'uen one passes places where the Pao Ching Mining Company ${ }^{1}$ has sunk shafts, and is mining comparatively small quantities of coal. Along the line where cuttings have been made one can see thick seams of coal actually exposed.

Continuing in a direction a little south of west, it is noticed that the strata, now comprised of alternate beds of sandstone and shale, and varying in colour from a dark purplish brown to olive green and yellow ochre, still dip to the west. Steadily ascending, the railway line next passes through the Red Beds, which are red shales and sandstones forming the upper layers of the Shansi formation. Finally come the thick loess deposits of the Shouyang Hsien district, just before reaching which town, the highest point on the line, marking the divide between the Fên-Ho and the P'u-t'o Ho, is crossed (about 3,000 ft. altitude). From here a descent

1 This eompany was formed by the gentry of the province to exploit the mineral resourees (ehiefly coal and iron) after the redemption of the mining rights from the Pekin Syndicate, by the payment, it is said, of Tls. 2,250,000. The coneession was first obtained by the Pekin Syndicate in 1898, and was finally relinquished in 1907. Sinee that time the Chinese have really done very little to develop these vast mineral resources. 


\section{SPORT AND SCIENCE ON THE}

is made through thick beds of red sandstone (Red Beds), the strata of which dip still to the west. Just before Pei-ho-liu is reached, the red sandstone gives place to grey sandstone of a similar nature. Passing through this, the line comes out upon the alluvial plain of T'ai-yüan at Yü-tzŭ Hsien, and turning northward, terminates twenty miles further at T'ai-yüan Fu itself. From the train as it makes this last stretch can be seen the Lung-wang Shan, lying to the east. These mountains are composed of a massive outcrop of the Shansi coalbearing series, and though I have not actually determined such to be the case, are doubtless formed by a large anticlinal fold, as they rise to a greater altitude than the Red Beds at Shouyang Hsien. Anthracite coal is mined here at an altitude of fully 3,000 feet. This seems to mark the western boundary of the anthracite beds, for in the mountains immediately west of the plain bituminous coal only is mined.

\section{PART 2}

The Geology of the Country traversed by Anderson and the Author in 1908 : Northern Shensi, the Ordos and Western Shansi

On my journey with Anderson through North Shensi, along the Ordos border and into Western Shansi, I kept some note of the geological formations. 
PLATE XVII.

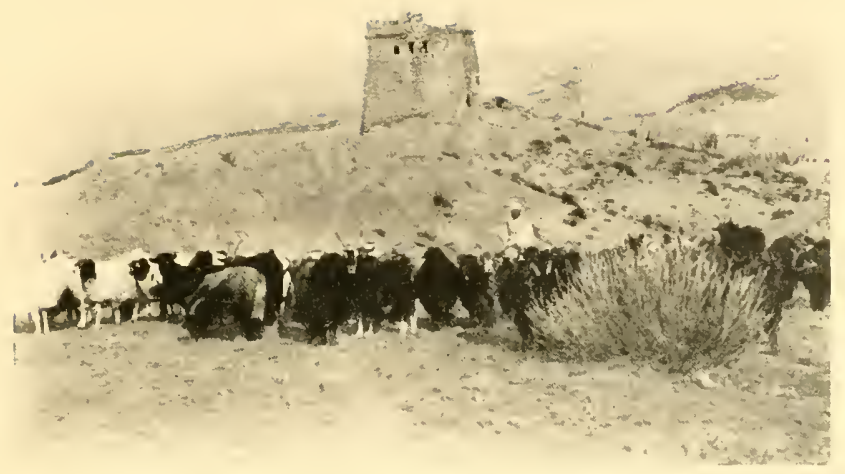

A Tower of the Great Wall, Ordos Border.

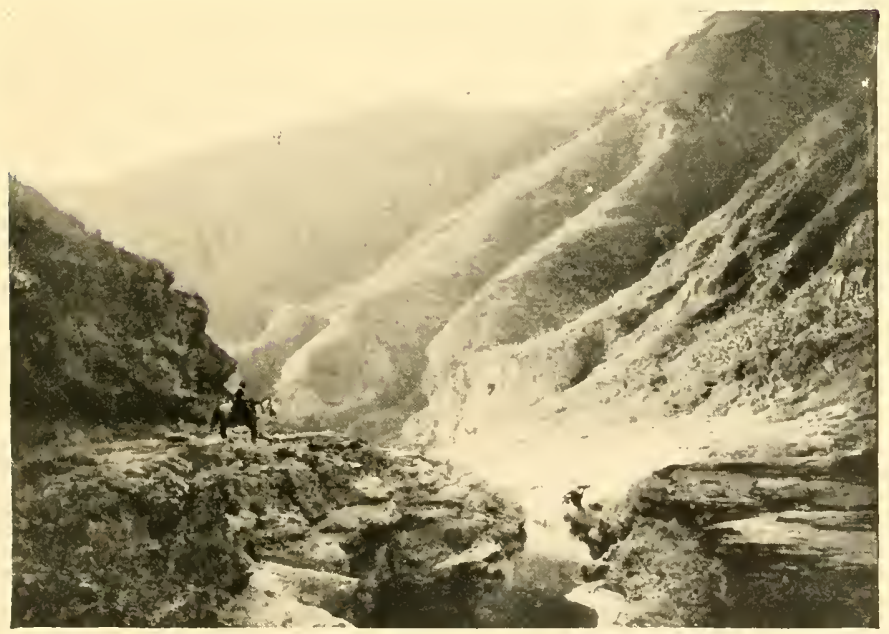

Loess Ravine in North Shensi.

Opposite p. 258.] 



\section{SINO-MONGOLIAN FRONTIER}

As the Clark Expedition subsequently traversed a good portion of our route, and as I have already published notes on the geological formations along that portion, there is no need to go over it again here.

From Yen-an $\mathrm{Fu}$ to Ching-pien Hsien we travelled up the valley of the Yen-shui, and noted that the sandstone strata, usual in North Shensi, occurred all the way, without fault and practically horizontal. As far as I can make out this sandstone belongs, or at least corresponds, to the Red Beds, which form the upper strata of the Shansi formation. What corroborates this supposition is the fact that no coal seams appear along the ravines, as is the case in the coal-producing districts of Shansi, yet coal is extensively mined throughout North Shensi, vertical shafts being sunk to reach the seams. As the average altitude of the upper surface of the sandstone strata does not exceed 3,000 feet, it follows that the Shansi coal measures are very much higher than those of Shensi. Further, there seems to be no reason to suppose that they are two distinct systems, so that one can only suppose that the strata of North Shensi must lie in an extensive and shallow synclinal fold, or that they have become depressed below those of Shansi owing to faults somewhere along the course of the Yellow River. We know that there is a series of faults with downthrow on the west, running roughly parallel with the Yellow 


\section{SPORT AND SCIENCE ON THE}

River, marking out the course of the Fên Ho in Shansi. There seems to be no special reason why there should not be a second series of faults down the course of the Yellow River. As a matter of fact, wherever I have crossed the latter from Shansi into Shensi, I have noticed that the mountains on the Shansi side are higher and more precipitous than those on the Shensi side, while the strata on either side do not correspond at all well.

Near the head of the Yen-shui valley red sandstone replaces the grey or yellow. Here the loess mantle is very much thicker than elsewhere. At Ching-pien Hsien no outcrop of sandstone is visible, as the course of the stream cuts deeply through hardened sand and dark sun-baked mudstone.

Continuing into the desert we encountered nothing but sand, alternating with stretches of pale blue-grey clay, in which were lagoons and small lakes. As we travelled north-eastward from here, along the border, we again encountered the red sandstone lying beneath the enormous deposits of sand, or in places sand and clay mixed. Near Yü-lin $\mathbf{F u}$ this gave place to yellow-grey sandstone once more, which continued till we again neared the Shansi border, when the shales, typical of the Shansi series, once more presented themselves, underlying the sandstone. Again at Pao-tê Chou the difference in levels of the strata 


\section{SINO-HONGOLIAN FRONTIER}

was very noticeable. Working south-east from Pao-tê Chou, we shortly encountered limestone, belonging to the $\mathrm{Ki}$-ch'ou formation, the strata of which dipped gently to the west. Rising steadily up through this, we reached a high ridge of limestone, descending from which we again reached the sandstone of the Shansi formation, in which the town of K'o-lan Chou is situated, and which extends eastward from here to the Fên Ho. Though we had crossed the great ridge dividing the basin of the Fên Ho from the Yellow River, we did not encounter any of the usual archaic formations. This then forms one of the few breaks in the continuity of the archaic ridge, which runs from Ningwu Fu to Yung-ning Chow in Western Shansi.

From K'o-lan Chou we journeyed northward to Wu-tsai Hsien, crossing a low ridge in the Shansi formation, and from Wu-tsai eastward to Ning-wu Fu, crossing a somewhat higher ridge in the same formation. Here we noticed bituminous coal being mined close to the city. Northward from Ning-wu Fu I noticed the Shansi formation extending for some distance, but I did not pursue my investigation very far in this direction.

Leaving Ning-wu Fu we journeyed eastward, soon encountering the Sinian limestone, followed by limestone of the Hu-t'o series, originally described from close to this very region by Bailey Willis. A little to the west of T'ai-niu-tien, the limestone 


\section{SPORT AND SCIENCE ON THE}

is cut through by a dyke of granite, probably belonging to the T'ai-shan complex, which forms the basal complex of the formations of the $\mathrm{Wu}$ - $\mathrm{t}^{\text {'ai }}$ Hsien district.

We crossed the alluvial plain and reached Hsinchou, at which point we joined the route taken by Bailey Willis' party on its way from Wu-t'ai Hsien to T'ai-yüan Fu.

Striking south from Hsin-chou, we crossed the south-western terminus of the Ki-ch'ou Shan, where occur the typical Sinian limestones, which Bailey Willis has called the Ki-ch'ou formation, and which are of the Cambro-Ordovician period.

The Ki-ch'ou Shan run from north-east to southwest along the south-eastern margin of the Hsinchou plain. The range consists of a massive scarp on the north-west and a dip slope on the southeast, as a result of an extensive fault, running in the same direction as the range. This fault is one of a series, which, as already stated, extend down through Shansi. The next in the series occurs, in the opinion of the author, along the north-western margin of the T'ai-yüan Fu plain, where again the limestone rises in a massive and precipitous scarp; only in this case the downthrow is on the southeastern side. Considering the general westerly dip of the strata from the Chihli plain to well west of T'aiyüan $\mathrm{Fu}$, and the merging of the upper rocks of the Shansi formation into the T'ai-yüan plain on its eastern margin, the sudden recurrence of the limestone 


\section{SINO-MONGOLIAN FRONTIER}

on the western margin of the same plain can only be explained by the existence of a fault, such as I have just described. Indeed there is no reason why a fault should not occur here, for further south and in an almost direct line with it a similar fault occurs, running in a direction slightly west of south, along the eastern side of the O Shan. In this also the downthrow is on the east. Richthofen, also, came to the conclusion that there was a fault along the north-western margin of this plain.

We put up at Huang-t'u-tsai, the place which gives its name to the Huang-t'u formation, a name given by Bailey Willis to the loess and various other Quaternary deposits of North China.

The following day we continued down a dry stream bed and finally came out upon the T'ai-yüan $\mathrm{Fu}$ plain once more.

\section{PART 3}

The Geology of the Upper Fên Ho Basin, Vestern Shansi

The geology of the country lying north-west of the T'ai-yüan Fu plain, owing to the extensive fault running down its north-western margin, is in many ways a repetition of that of the country traversed by the Chên-T'ai Railway. A new feature, however, is presented in the form of extensive outcrops of plutonic and metamorphic rocks. 


\section{SPORT AND SCIENCE ON THE}

Hitherto this country has scarcely been touched by any geologist; so that the following notes, though far from complete, may be considered as breaking new ground. They were gathered on the trip described in the second chapter of this book.

Let us take a line running north-west from T'ai-yüan $\mathrm{Fu}$, through Tsing-lo Hsien, Wu-chiakou, Tien-p'ing to Wu-tsai Hsien, and consider in section the different formations.

First after crossing ten or twelve miles of alluvial plain, loess and stony river bed, we encounter the extensive escarpment of Ki-ch'ou limestone, caused by the fault running north-east to southwest. Entering a deep gorge at Kuan-k'ou, we note that the strata at first are horizontal, though slightly folded; but that further on they dip slightly in a general north-westerly direction. Continuing along the bottom of the ravine, which rises steadily through the limestone, Pei-hsiaotien, ten miles from Kuan-k'ou, is reached. This is a small town situated at an altitude of 4,570 feet in an open valley in the Shansi coal measures, where bituminous coal of the usual quality is mined. We have thus ascended roughly 2,000 feet, through the Sinian limestone to the Shansi formation.

On leaving Pei-hsiao-tien the road continues north-westward, ascending a narrow valley. Here metamorphic rocks, consisting chiefly of 


\section{SINO-MONGOLIAN FRONTIER}

schist, with veins of quartz running through it, abruptly replace the sedimentary rocks. Ascending the steep pass, first a broad vein of dark basalt containing a high percentage of iron is encountered: subsequently two high ridges formed by a massive dyke of granite are crossed.

The metamorphic rocks, which are not very extensive, may owe their existence to the granite, as, judging from the stratigraphy of the district, it seems probable that the granite is an intrusion of later date than the limestone and coal measures.

On the western descent the outcrops show the same rocks as on the east (i.e. granite and schist). These, however, are soon replaced by Ki-ch'ou limestone of an equal height with that east of the passes, with a slight north-westerly dip. As may be expected, this gradually gives place to the carboniferous series (Shansi formation) once more. Soon the Fên Ho is reached (at Tsing-lo Hsien), crossing the valley of which, we still find the sandstone and shales of the Shansi formation. The strata here, however, are now horizontal for a short distance, subsequently dipping more and more sharply to the south-east, till they are almost perpendicular. They are suddenly replaced by almost perpendicular strata of limestone (Ki-ch'ou). These form a high ridge, with a dip slope on the southsouth-east of at least $80^{\circ}$, and a very steep escarp- 


\section{SPORT AND SCIENCE ON THE}

ment on the north. This clearly indicates the existence of a great synclinal fold in the sedimentary rocks, extending from the north-west of the granite dyke, near Pei-hsiao-tien to this point.

Wu-chia-kou lies in the valley to the north of this ridge of limestone. It must be noted that our section crosses this ridge somewhat obliquely. The northern slope of this valley is of red sandstone belonging to the Man-t'o Shales, the strata of which lie unconformably against schists of the Wu-t'ai series, and also dip sharply to the south-east. The rocks of the Wu-T'ai series are soon replaced by a great mass of basal complex, probably equivalent to the T'ai-shan complex. The outcrops of granite here are very extensive, and form the mass of the mountain chain, which rises to a great height (10,000 feet), and is about five miles wide.

On the north-western slope of this massive range of archaic rock, limestone, similar to that on the east, lies unconformably against the older systems ; but, dipping sharply to the northwest, it is soon replaced by sandstone of the Shansi formation, also dipping sharply to the north-west and merging into the Wu-tsai plain.

The occurrence and dip of the sedimentary rocks on this side of the range, suggest that the strata lie in the form of an immense anticline, the apex of which has been denuded, 


\section{SINO-MONGOLIAN FRONTIER}

exposing the archaic formations beneath. On the north-western side of the range the strata flatten out and probably continue horizontally up to and beyond the Yellow River. I did not notice any sign of the Hu-t'o series, but doubtless they exist.

North-east from Wu-chia-kou the geology of the country immediately adjoining the Ningwu $\mathrm{Fu}$ district, as already stated in my geological notes in Through Shên-Kan, shows a series of shale and sandstone ridges (Shansi formation), the strata of which dip to the east at angles varying from $30^{\circ}$ to $80^{\circ}$. The ridges are formed by escarpments on the west and dip slopes on the east. It is in some of the higher and more. gentle hollows, caused by this configuration, that lie the fresh-water lakes, mentioned in Chapter II of this book as having been newly discovered in January of 1910.

Here again the Shansi formation is replaced westward by the Ki-ch'ou formation (limestone), the strata of which dip to the east at very sharp angles. The outcrop of archaic rock, which has extended unbroken north-east from the $\mathrm{Wu}$ chia-kou district, has tapered down, disappearing altogether before Ning-wu Fu is reached. 


\section{SPORT AND SCIENCE ON THE}

\section{PART 4}

The Geology of the Country traversed by the Peking-Kalgan Railway

From Peking to Nan-k'ou the railway traverses part of the Chihli plain. As one approaches Nan-k'ou, low limestone hills, outliers from the main range, can be seen. In these the very marked strata dip at an angle of about $45^{\circ}$ to the south-east. The same thing may be seen in the lower slopes of the main range. The strata of the higher levels, however, are horizontal, and, though the actual contact cannot be clearly made out from the train, suggest the existence of two unconformable formations of limestone. This is the case, the sharply dipping strata of the lower slopes and outliers having been identified as belonging to an older formation called the Nankou series, which finds its equivalent in Shansi in the Hu-t'o series already mentioned.

Ascending the valley, at the mouth of which Nan-k'ou is situated, one soon reaches a level above the Nankou limestone, and finds the Tayang limestone (Sinian), the equivalent of the Ki-ch'ou limestone in Shansi, lying in horizontal strata. Further on up the valley these commence to dip to the north-west, and are interbedded with blue clays and shales. Finally the strata become contorted, and are replaced by plutonic 


\section{SINO-MONGOLIAN FRONTIER}

rocks, consisting chiefly of light buff-coloured granite. This formation continues to well beyond the crest of the ridge, till the mountains give place to a wide plain-the valley of the Ta-sha Ho, which joins the Ta-yang Ho a little to the south.

Crossing this plain in a north-westerly direction, a second range is encountered, which runs from east-north-east to west-south-west, and consists, as far as can be judged from the train, of limestone formation (probably Ta-yang limestone).

Near Hsia-hua-yüan, where the Ta-yang Ho cuts through this range in a narrow and deep valley, the sedimentary rocks become rather complicated. Coal-bearing sandstone and shale strata lie underneath the limestone, an unconformity between the two formations being distinctly discernible. This can only be explained by the existence of an overfold or overthrust. The coal-bearing strata are more or less horizontal and somewhat folded, while the limestone shows perpendicular or very sharply dipping strata.

North-west of Hsia-hua-yüan, for a considerable distance, horizontal strata of purple shale and sandstone occur. These next give place to limestone, which extends to within six miles of Kalgan, when it is replaced by the volcanic rocks of the Kalgan district. In our rambles through the hills round this town we found porphyry, chiefly 


\section{SPORT AND SCIENCE ON THE}

of a brown or brick-red colour, and other volcanic rock in great confusion. Specimens of serpentine and metamorphosed felspathic rocks were also obtained. To the north-west, basalt is exposed in the deep cutting of the stream bed, which ends in the Han-nor-pa pass. Further up this valley extensive beds of volcanic ash occur, which at first sight might be mistaken for the sedimentary rocks of the Shansi formations. The deposits are of a bright red colour, and in places assume the form of conglomerates, with large wellrounded boulders. This suggests that these beds were laid under water. Nearer the pass, these deposits are much lighter in colour, being pink or buff and light blue-grey. In places the original substance has degenerated into soft clay, while, wherever the strata assume the form of conglomerate, the fragments of harder rock are roughedged and not rounded as they are nearer Kalgan. Beyond these beds basalt occurs right up to and beyond the Han-nor-pa pass.

\section{PART 5}

The Geology of the Ch'ing Ho and Hsi-wantZǓ District, Northern Chinli

Leaving Kalgan we travelled northward up the valley of the P'an-chang Ho for about six miles. The sides of this valley are steep and composed entirely of outcrops of trachyte of a mauve grey 


\section{SINO-MONGOLIAN FRON'TIER}

colour. This colour on the exposed surface is changed, through weathering, to a dark brown. Typical crystals of felspar occur throughout the mass. In the specimens gathered the crystals had undergone considerable decomposition.

At a place called IIsi-tien-tzŭ the valley takes a bend eastward, at right angles to its original course, while a wide but waterless valley enters it from the north. This is called Ching-kou, while the main valley, which has a good permanent stream, is now called Ch'ing Ho.

The trachyte continues all the way to Kaochia-yin-tzŭ, just beyond which place it ends. Here it is of a lighter colour, the weathered surface being of a bright brick red, while the new fracture shows the rock itself to be of a light mauve-grey. The white crystals of felspar are also much larger and more noticeable than in the outcrops nearer Kalgan. Where they are exposed at the surface, these crystals rapidly disintegrate and are washed away, leaving the surface rock full of holes, which gives it something the appearance of a rock charged with air-bubbles.

Beyond Kao-chia-yin-tzŭ, still working eastward, we found metamorphic (chiefly gneiss) rocks, alternating with plutonic (granite), the former predominating.

Both the metamorphic and plutonic rocks are seamed with stringers, leads and ledges of quartz (probably auriferous). 


\section{SPORT AND SCIENCE ON THE}

At Hsin-yin-tzŭ the valley bends northward again, and subsequently continues winding in a general north-easterly direction to its source. From this village the outcrops are entirely of granite, felsite and serpentine, no metamorphic rocks occurring, till, just before Hsi-wan-tzŭ is reached, an extensive outcrop of gneiss is encountered.

Beyond Hsi-wan-tzŭ (i.e. to the east) we found the mountains to be composed entirely of a dark grey-brown or purple-grey trachyte containing the characteristic white crystals of felspar.

\section{PART 6}

The Geology of the Country traversed By the Chang-sut Extension Line, Northwestern Chihli and North-eastern Shansi

From near Kalgan to Tsai-kou-pu this railway line traverses obliquely the wide valley of the Yang Ho, crossing a great mass of detritus brought down from the north. After leaving Tsai-koupu it follows a tributary of the Yang Ho, called the Nan-yang Ho, and soon passes through a range of mountains composed entirely of metamorphic rocks, soft mica schists greatly predominating. In places the schists show very marked stratification.

Beyond this the valley widens out and the line no longer hugs the mountain side. Immense 


\section{SINO-MONGOLIAN FRONTIER}

masses of detritus, brought down from the mountains to the north, are crossed by the track, and they testify to the enormous amount of denudation that is taking place here. An examination of the rocks shows that the mountains to the north are composed mainly of granite and gneiss. These conditions prevail as far as Yang-kao, the present terminus of the line.

No sedimentary rocks of any kind were noticed on this journey, except the massive limestone forming a tall range on the south side of the Yang Ho valley. Elsewhere on the lower slopes a considerable amount of loess was noticed.

The schists noticed near Tsai-kou-pu probably belong to the same formation as the Wu-tai series, or are equivalent to it, while the granite and gneiss beyond are doubtless equivalent to the T'ai-shan Complex.

\section{PART 7}

The Geology of the Country from YangKaO To K'UEI-HUA-CH'ÊNG, North ShansI

As already stated, Yang-kao is situated on the eastern edge of the Ta-t'ung $\mathbf{F u}$ plain. To the north lies a great chain of tall rugged mountains. These seem to be composed mainly of metamorphic rock, gneiss being the only rock we encountered on entering these mountains on our way to K'uei-hua-ch'êng. 


\section{SPORT AND SCIENCE ON THE}

The gneiss continued as far as Kuan-t'ung-pu (about 20 miles N.N.W.). West of this place igneous rock prevails, an immense lava flow forming a plateau some ten miles wide (length not ascertained, but considerable). The basalt, which marks the eastern limit of the North Shansi basalt, is typical of the same, being of a dark blue-grey colour, with air holes, usually lined with spar and containing crystals of hornblende. In places where the surface of the plateau is bare of soil the basalt shows distinct hexagonal cleavage, indicating columnar structure beneath. This lava flow, judging from the general contour of the country, is roughly from north to south. The plateau ends abruptly on its western side in a deep river valley, running from north to south. Westward other lesser plateaux occur, however, and travelling along the river valley, which now runs east and west, fine examples of columnar structure are to be seen, notably near Fên-chêng. At this place good clay occurs, enabling extensive pottery work to be carried on.

The volcanic formations continue from here all the way to the T'ai Hai. North of this lake the mountains are entirely of granite as far as Mei-tê-êrh (Mei-teul), at the edge of the K'ueihua-ch'êng plain.

Some of this granite, notably that occurring up the valley east of Mei-tê-êrh, contains large quantities of garnets, some of which are as large 


\section{SINO-MONGOLIAN FRONTIER}

as marbles. All the granite up this way is of a pale buff colour.

The hills south of the lake are of basalt, as also are those on the west as far as the pass beyond Ning-yüan. Here an extensive outcrop of granite, a continuation of that occurring north of the lake, extends as far as Yang-p'o-yao-tzŭ. From this point to the edge of the K'uei-hua-ch'êng plain basalt occurs, showing fine columnar structure. The basalt and granite are frequently superimposed by loess, but not to any very great depth or extent.

No outcrops of any kind occur on the plain, which is mainly alluvial, with patches of winddeposited sand.

The T'ai Hai (lake) lies in an immense basin some twenty miles long and ten miles wide. This basin is bounded on three sides by low hills of volcanic formation, and on the fourth (the north) by high mountains of granite. It is difficult to explain the existence of this hollow in which the lake lies. The latter is said to be very deep in the centre. At first one might suppose that it occupies the crater of an extinct volcano, but this is by no means certain. Further investigation is needed before such a theory can be confidently advanced. It would, however, be interesting to know the origin of all the basalt, so prevalent in this country.

Referring to the mountains north-west of K'uei- 


\section{SPORT AND SCIENCE ON THE}

hua-ch'êng, where we hunted wild sheep, I find the following notes in my diary :-

"These mountains are entirely plutonic, volcanic, and metamorphic. The low foothills, which run in a series of low parallel ridges, are composed of lava (porphyry). Next (working westward) comes some white and greenish stone, which I take to be a metamorphosed felspar. Beyond this and rising to a great height, with deep cut ravines and valleys, come gneissic and schistose rock, with intrusions of granite. Working still west an extensive outcrop of white marble is crossed. Beyond this again the rock seems to be granitic, gneissic and schistose. The schists, I believe, are chloritic, while the granites certainly have a large proportion of felspar. A certain amount of iron-stone, but no coal, was noticed."

Probably the mountains north and north-east of K'uei-hua-ch'êng are similar in formation to those north-west.

\section{PART 8}

The Sedimentary Rocks North-west of PICh'Ien-ch'I, North-Western Shansi

From K'uei-hua-ch'êng to Pi-ch'ien-ch'i we traversed low-lying country at the foot of mountains and hills of the usual archaic formations.

North-west of Pi-ch'ien-ch'i, where we entered the mountains, we encountered extensive beds of 


\section{SINO-MONGOLIAN FRONTIER}

sedimentary rocks, doubtless belonging to the Shansi formation. First we came to some very massive conglomerate. This is composed of large cobbles and small boulders, held together by a very hard matrix containing sand and small pebbles. The strata of this conglomerate, which are very marked, and often over ten feet in thickness, dip to the north-west at angles varying from $45^{\circ}$ to $80^{\circ}$.

They are interstratified with small, pinched-out seams of coal and soft shale. In places the conglomerate is much contorted.

At Wu-lan-pan, a village six miles north-west from $\mathrm{Pi}$-ch'ien-ch'i, the conglomerate gives place to pink and yellow sandstone, with a much gentler dip (about $20^{\circ}$ N.W.).

Beyond Wu-lan-pan the conglomerate again appeared, underlying a dark brown shale, this time at a dip equal to that of the sandstone. After this we came to high mountains, composed chiefly of metamorphic rocks, through which great masses of granite protrude, forming a system of high peaks. No volcanic rock was noticed in this district.

My friend Mr. Nyström, already mentioned in Part I of this chapter, tells me that, when in the mountains north of Sa-la-ch'i (or Saratsi), one day's journey west of this point, he encountered outcrops of sedimentary rocks exactly similar to those described above, and, like me, he arrived 


\section{SPORT AND SCIENCE ON THE}

at the conclusion that they belonged to the Shansi formation.

\section{PART 9}

The Geology of the Mongolian Plateau, InNer Mongolia

Throughout the whole of this journey nothing but igneous and metamorphic rocks were encountered. In general it may be stated that this portion of the Mongolian Plateau is formed by an extensive lava-flow (or flows), traversed by dykes of granite and quartz, the last occurring with less frequency than the others. Whether these dykes are of an older date than the basalt it is not easy to say.

Topographically the area beyond the steep ascent of the Han-nor-pa pass consists of very slightly undulating plains of a uniform altitude (about 4,000 feet), bounded or traversed by small ranges of low, rocky, partially grass-covered hills. The extremities of these are frequently joined by almost imperceptible ridges. Sometimes they end in abrupt cliffs, but most often they slope gently into the plain. In the valleys there are usually shallow lagoons of varying sizes; while occasionally permanent streams of clear, sweet water wind through very clayey soil. The soil round the lagoons is also very argillaceous.

The ascent of the Han-nor-pa pass is through 


\section{SINO-MONGOLIAN FRONTIER}

basalt of a dark grey colour, not unlike that encountered in Shansi, while in the valley leading up to it various kinds of rock, all igneous, were noticed. Amongst others, we gathered specimens of a red-brown porphyry containing numerous elongated air-holes, besides distinct crystals of felspar and quartz. Specimens of metamorphosed felspar, of light grey basalt, and of a peculiar yellow sandstone, were also gathered. The predominating rock throughout, however, was found to be basalt, and, nearer to Kalgan, trachyte.

Except in the hills and on the ridges of the Plateau, the thick grass-covered surface soil prevented our noting the nature of the sublying rock, but an examination of the outcrops in the hills showed that basalt greatly predominated, while dykes of granite occurred here and there. As we approached Lama Miao the granite increased in proportion till it seemed, sometimes, as if dykes of basalt crossed the general mass of granite. Usually, however, the higher ridges were found to be of granite, while wherever the sublying rock in the lower slopes and valleys was visible it usually turned out to be basalt. At a place named Oola Hutaga some gneiss was noticed, but here also the hills were chiefly of granite and volcanic rock.

At Tabool we noticed some wide veins of quartz running north and south through metamorphic and granitic rocks. This quartz was not noticed 


\section{SPORT AND SCIENCE}

elsewhere. Here also some outcrops of muscovitic schist occurred.

It was stated by one of the missionaries that twenty li (about 6 miles) south-west of Hallo Ossa (near Tabool), the Chinese were excavating for coal. This would suggest an outcrop of the coal-bearing sedimentary rocks noticed west of K'uei-hua-ch'êng.

From Tabool south to Kalgan the outcrops showed almost entirely volcanic, with a little granite. 
APPENDIX 



\section{ITINERARIES}

\begin{tabular}{|c|c|c|c|c|c|}
\hline 官 & From & To & $\begin{array}{c}\text { Dis- } \\
\text { tance } \\
\text { in } \\
\text { MHes }\end{array}$ & Stages & Remarks. \\
\hline 1 & T'ai-yuan Fu & Sui-tê Chou & 180 & 9 & Via Fên-chou Fu \\
\hline 2 & Yen-an Fu & Yü-lin Fu . & 211 & 10 & Via Ching-pien Hsien \\
\hline 3 & Yü-lin Fu & Pao-tê Chou & 136 & 5 & \\
\hline 4. & Pao-tê Chou & Ning-wu Fu & 121 & 6 & Via Ko-lan Chou \\
\hline 5 & Ning-wu Fu & T'ai-yuan Fu & 101 & 4 & Via Hsin Chou \\
\hline 6 & T'ai-yuan Fu & Ning-wu Fu & 106 & 6 & Via Tsing-lo Hsien \\
\hline 7 & Kalgan & Hsi-wan-tzŭ & 381 & 2 & \\
\hline 8 & Yang-kao & $\begin{array}{l}\text { K'uci-hua- } \\
\text { ch'êng }\end{array}$ & 127 & 6 & Southern Route \\
\hline & ", & , & 133 & 7 & Northern Route \\
\hline
\end{tabular}

ITINERARY No. 1.

T'ai-yuan Fu to Sui-tê Chou (via Fên-chou Fu).

Distance, 180 miles; 9 stages.

There is a cart road as far as Fên-chou Fu, which is good in winter but sometimes impassable in the rainy season. From Fên-chou Fu, only mule traffic is possible.

Stage 1. Chin-esŭ (15 miles). General direction : S.W. Traverse level plain, crossing Fên Ho (by bridge in winter, ford or ferry in summer) two miles S.W. of T'ái-yuan Fu. Pass through low-lying fields to base of hills, where the road becomes rocky. Good inn at Chin-ssŭ, and fine old temple. 


\section{APPENDIX}

Stage 2. K'ai-shi (27 miles). General direction : S.W. Road good all the way. Pass important town of Chiao-ch'êng Hsien (20 miles), where there are inns. Inns at K'ai-shi very bad.

Stage 3. Fên-chou Fu (24 miles). General direction : S.W. Pass important town of Wên-sui Hsien (10 miles). Good inns at Fên-chou Fu. Latitude (East Gate) $37^{\circ} 15^{\prime} 42^{\prime \prime}$ N., Longitude $111^{\circ} 48^{\prime} 2^{\prime \prime}$. Altitude 2,600 ft.

Stage 4. Wu-ch'eng (24 miles). General direction: West. Travel up loess valley and crossing a pass descend into limestone eanyon at Hsiangyang (10 miles). Follow up canyon and cross high pass descending rough stony valley to Wu-ch'êng. Several inns at Wu-ch'êng.

Stage 5. Yung-ning Chou (15 miles). General direction: West. Follow river valley along a good road. Good inns at Yung-ning Chou.

Stage 6. Liu-lin-chên (15 miles). General direction : S.W. Road follows down valley, first south 5 miles and then west. Good inns at Liu-linchên, which is a prosperous place.

Stage 7. K'ang-chia-t'a (20 miles). General direction: N.W. Continuing down the valley for about 8 miles the road hugs the side, finally turning abruptly up a side ravine. A very steep ascent to high loess pass, and winding descent to bed of Yellow River. This is crossed by ferry. Road follows along the right bank in a westerly direction for $\mathbf{5}$ miles to $\mathrm{K}$ 'angchia-t'a, where there is a good inn.

Stage 8. Yi-ho-ch'êng (20 miles). General direction: N.W. A stiff climb on leaving K'ang-chia-t'a, followed by some miles over loess tops, and 


\section{APPENDIX}

then descent along winding ravine to $\mathrm{Yi}$-hoch'êng. Good mule track. Several good inns at Yi-ho-ch'êng.

Stage 9. Sui-tê Chou (20 miles). General direction: West. N.W. up deep loess ravine, over loess pass and S.W. down second ravine to valley of Wu-ting-Ho, up course of which 8 miles to Sui-tê Chou, situated on the right bank. Good mule track. Good inns in south suburb. Latitude (South Gate) $37^{\circ} 29^{\prime} 51^{\prime \prime}$ N., Longitude $110^{\circ} 13^{\prime} 49^{\prime \prime} \mathrm{E}$. Altitude $2,300 \mathrm{ft}$.

For Itinerary of the journey from Sui-tê Chou to Yen-an Fu, vide "Through Shen-Kan," Appendix I (a), pp. 159-161.

\section{ITINERARY No. 2.}

Yen-an Fu to Yü-lin Fu (via Ching-pien Hsien). Distance, 211 miles; 10 stages.

Mule track all the way, though big wheeled carts could be used in the Ordos.

Stage 1. Chou-tung (20 miles). General direction: N.W. Good mule track following valley all the way. Pass An-sai Hsien (15 miles), where there are inns. Cross river once or twice without difficulty. Good inn at Chou-tung (a small village).

Stage 2. Hua-tzŭ-p’ing (23 miles). General direction: N.W. Road same as stage 1; passing a few small villages. Cross river several times. Good inn at Hua-tzŭ-p'ing.

Stage 3. Ma-tzŭ-wan (30 miles). General direction : N.W. This journey is made arduous by numerous fordings of the river, 68 in number, but not 


\section{APPENDIX}

hard, especially toward the end. Near head of valley a steep and difficult ascent leads to small farm and inn called Ma-tzŭ-wan. No other stopping place. Poor inn.

Stage 4. Ching-pien Hsien (18 miles). General direction: N.W. A mere bridle-path descending into a deep valley. Ascending other side and crossing sandy flats reaches Ching-pien Hsien, where there are several inns.

Stage 5. Ning-t'iao-liang (10 miles). General direction: North. Immediately on leaving Chingpien, a treacherous stream in a deep ravine must be crossed. Ascending on to flat plain the road leads straight north over sand to scattered farms (Chinese) called Ning-t'iaoliang. No inns.

Stage 6. Hung-tu-er Chieh $(20$ miles). General direction: N.E. Road lies over sand hills crossing here and there low ridges of harder ground. Sand very hard to walk in. Road not always easy to discern, especially after sandstorm. Very bad inns.

Stage \%. Ma-ni Ho (20 miles). General direction : N.E. Road same as stage 6. Cross a river named Chang-feng-pan Ho (15 miles). Ma-ni Ho on a small river of same name. Poor inn. Stage 8. Hai-lin-t'u Ho (20 miles). General direction: N.E. Road same as stage 6, but more sand hills. Hai-lin-t'u Ho also on small river of same name. Poor inn.

Stage 9. Hung-t'u-er (25 miles). General direction : N.E. Road even more sandy than stage 8 ; the soft sand making very hard going. Rather good inn. 


\section{APPENDIX}

Stage 10. Yü-lin Fu (25 miles). General direction: N.E. Road very sandy and going very hard, otherwise same as preceding stages. Just before reaching Yü-lin Fu strike river bed and turn S. 4 miles to the city.

Yü-lin Fu, Latitude (South Gate) $38^{\circ} 16^{\prime} 54^{\prime \prime}$. Longitude $109^{\circ} 44^{\prime} 59^{\prime \prime}$ (Clark).

\section{ITINERARY No. 3.}

Yü-lin Fu to Pao-tê Chou.

Distance, 136 miles; 5 stages.

Between these two places there is only a mule track. In places where this skirts deep ravines in the loess it is rather dangerous. The country is very barren and food and fodder are scarce.

Stage 1. Tuan-ch'iang (20 miles). General direction : N. Sandy road all day. Hard going. Midday halt at Chang-lo-pu. Deep loess gullies make road rather dangerous towards end of day's journey. Tuan-ch'iang is an inn; there are no others.

Stage 2. Kao-chia-pu (23 miles). General direction: N.E. First part of road dangerous owing to treacherous path along deep loess ravines. The road crosses the Wall and makes detour into sandy desert. Midday halt at T'uoh-nieh-tzŭ-kou. Road follows stream from here eastwa.d to Kao-chia-pu, inside the Wall. Good inns.

Stage 3. Shên-mu Hsien (33 miles). General direction: N.E. Road less dangerous, though still sandy and tedious. It follows stream bed, ascending hill to Pei-li-pu, descending other 


\section{APPENDIX}

side, it next turns N.N.W. up a large valley to Shên-mu Hsien. Good inns.

Stage 4. Chêng-hsiang-pu (27 miles). General direction: N.E. Road follows up river bed to Yung-shing-pu, where midday halt is made. Climb hills to Chêng-hsiang-pu. Good inns.

Stage 5. Pao-tê Chou (23 miles). General direction : East. Descend stream bed all the way. Stop for midday at Ku-shan-pu. Road fairly good. Reaching Yellow River at Fu-liu Hsien, the crossing is effected by means of ferries. Paotê Chou on left bank. Good inns in suburb.

\section{ITINERARY No. 4.}

Pao-tê Chou to Ning-wu Fu.

Distance, 121 miles; 6 stages.

This is a rough journey, in which two ranges of hills are crossed. There is only a mule track.

Stage 1. Ta-t'a-pu (15 miles). General direction : E.S.E. Crossing the ridge on which Pao-tê Chou stands, the road descends into a deep ravine up which it follows all the way. Midday halt at Ch'iao-tóu. Good inn at Ta-t'a-pu.

Stage 2. Shih-tzŭ-yieh (27 miles). General direction : E.S.E. The road continues up the same ravine. Midday halt at Sui-yü-kuan. At the end of ravine a steep ascent brings one to the crest of a high ridge, where Shih-tzü-yieh (a farm) is situated. Lack of water in this country.

Stage 3. K'o-lan Chou (10 miles). General direction : S.E. This stage is a short one, the road follow288 


\section{APPENDIX}

ing down a deep and stony ravine to K'o-lan Chou. Good inns.

Stage 4. Wu-tsai Hsien (24 miles). General direction: N.E. Cart road aseends dry stream bed to its souree. A low ridge is crossed, and the road enters Wu-tsai plain. Road rather stony. Good inns at Wu-tsai.

Stage 5. Ch'ên-ch'eh Hsien (24 miles). General direction: N.E. Road less stony; good for carts. Very low ridge is crossed not far from Wu-tsai. Inn aecommodation poor at Ch'êng-eh'ch.

Stage 6. Ning-wu Fu (10 miles). General direction : S.E. The road, a mere mule track, leads over a ligh ridge. Both aseent and descent are very steep. Good inns at Ning-wu Fu.

\section{ITINERARY No. 5 .}

Ning-wu Fu to T'ai-yuan Fu (via Hsin Chou). Distance, 101 miles: 4 stages.

An easy journey. The last three stages are good for cart traffic, though rather bad in very wet weather.

Stage 1. Tai-niu-ticn (27 miles). General direction : S.E. Road, a mule track, follows up canyon, crossing pass at top. Then descent is made into a long valley, which narrows down into a deep gorge just before it comes out on to the Hsin Chou plain. No inn at Tai-niu-tien.

Stage 2. Hsin Chou (35 miles). General direction : S.S.E. This is not the usual stage, but it can be made in summer by making an early start. Several small villages passed. The whole journey is along a cart road over the plain. 


\section{APPENDIX}

Stage 3. Huang-t'u-tsai (24 miles), General direction : South. After traversing plain for three miles (cross muddy river bed), an ascent is made and a low pass crossed. Subsequently road follows through Locss country sunken roads) to Huang-t'u-tsai. Heavy cart traffic and many inns along the road.

Stage 4. T'ai-yuan Fu (15 miles), General direction : S. The cart road continues down the dry stream bed, finally reaching the T'ai-yuan Fu plain. Road good exeept in rainy scason.

ITINERARY No. 6.

T'ai-yuan Fu to Ning-wu Fu (via Tsing-lo Hsien). Distance, 106 miles; 6 stagcs.

Stage 1. Pei-pan (12 miles). General direction: N.W. Cart road lies over the plain to this village. Good all the year cxeept in the rainy season. Two or three inns at this village.

Stage 2. Pei-hsiao-tein-tzŭ (20 miles). General direction: N.W. Road follows up stony river bed to Kuan-k'ou (3 miles), then enters deep gorge in mountain. There is a path up side and along the top of the gorge. This is easier going than the gorge bottom. 10 miles further to Ling-ching, the mid-day halt. Still continue up gorge, now more open, to Pei-hsiao-tien. Good inns.

Stage 3. Tsing-lo Hsien (27 miles). Gencral direction : N.W. Shortly after lcaving Pei-hsiaotein two high passes must be crossed. The road then deseends down stolly river bed to 


\section{APPENDIX}

K'ang-ehia-hui (12 miles). Continue westward down valley all the way to Tsing-lo Hsien on the Fen Ho.

Stage 4. Niu-hua-ch'êng (20 miles). General direetion: N.N.E. Follow up Fen Ho valley all the way. Going good. No cart road. Midday halt at Yuang-an-ehêng (9 miles). Poor inn. Stage 5. Tung-tsai (12 miles). General direetion: N.N.E. Still continue up Fên Ho valley. Road same as day beforc. Hua-pei-t'ung (5 miles). No inn at Tung-tsai.

Stage 6. Ning-wu Fu (15 miles). General direction : N.N.E. Cart road (very rough) follows stony valley up to its head. A very rough but not steep pass is erossed at Fên-sui-ling (5 miles). Descent into Hua Ho valley. Stony road all the way to Ning-wu Fu.

\section{ITINERARY No. $\%$.}

Kalgan to Hsi-wan-tzŭ.

Distanee, $33_{2}^{\frac{1}{2}}$ miles; 2 stages.

A very short, but at times difficult journey. The road prepared for eart traffic is very rough and in spring when the ice is melting, or in the rainy season it is very difficult. It could be done in one day, but is a bit long for that.

Stage 1. Hsin-yin-tzŭ (13 $\frac{1}{2}$ miles). General direction: W.N.W. Road as stated above. First 4 miles northward, then due west to Hsin-yintzŭ. Halfway halt at Kao-chia-yin-tzŭ. Suitable inns at both places.

Stage 2. Hsi-wan-tzŭ (20 miles). Gencral direction : N.IV. Road as above; follows stony valley 


\section{APPENDIX}

all the way. Poor inns at Hsi-wan-tzŭ. Catholic Mission has a large establishment.

\section{ITINERARY No. 8.}

Yang-kao to K'uei-hua-ch'êng.

Distance, Southern route, 127 miles; 6 stages; Northern route, 133 miles; 7 stages.

This journey is a comparatively easy one. There is a cart road all the way. From T'ien-ch'êng-ts'uen there are two routes; one south and one north of the Tai Hai. The northern is perhaps the easiest.

Stage 1. Kuan-t'ung-pu (20 miles). General direction: West. The road first crosses three miles of plain (northward). It then enters a winding stony gorge going westward, and crossing low ridge at its head follows a wide valley. Crossing a low loess plateau in N.W. direction it finally reaches Kuang-t'ung-pu. Good inn.

Stage 2. Fên-chêng (12 miles). General direction: W.N.W. Lcaving Kuan-t'ung-pu the road climbs on to a broad plateau, which it traverses for 8 miles, passing some scattered villages the largest of which is called He-ke-tawan-tzŭ. The western descent from the plateau is very steep and rough. 4 miles up the valley to Fên-chêng, which is an important placc with good inns.

Stage 3. T'ien-ch'êng-ts'uen (18 miles). General direction: W.N.W. The road first crosses a small flat plain, somewhat swampy, for 3 miles. It then crosses a ridge and reaches Ma-ts'angliang (5 miles). Following a valley up its 


\section{APPENDIX}

course it finally reaches 'T'ien-ch'êng-ts'uen, passing $\mathrm{Ma}$-wang-miao (5 miles). Good inns.

\section{SOUTHERN ROUTE.}

Stage 4. Hsiang-huo-ti (21 miles). General direetion: West. Leaving 'T'ien-ch'êng-ts'uen the road takes a westerly course for $\mathbf{5}$ miles, when it reaches the T'ai Hai plain at Fang-huo-chêng. It then crosses plain, keeping south of the lake, and reaches Hsiang-hua-ti, a eatholic village with a church and mission buildings. Poor inns.

Stage 5. Yang-p'o-yao-tzŭ (24 miles). General direction : West. Road goes westward, and, crossing a low pass into valley, reaches Ning-yuan-ting, passing several small villages on the way. Next it follows up a stony valley at whose head a steep pass is crossed. Descent down through stony valley, which gets very narrow and rough near Yang-p'o-yao-tzŭ. Two good inns.

Stage 6. K'uei-hua-ch'êng (32 miles). General direction: N.W. This is a long stage, and if necessary can be divided into two, a halt being made at Yang-ke-pa-er (8 miles from K'uci-huach'êng). The first 6 miles down stony valley, at whose mouth Hsi-k'ou-men is situated. Subsequently the road crosses the plain, the first 5 miles to Sha-pu-na (or Nor) being very sandy is hard going. Other villages from here on are He-t'an-wan ( $1 \frac{1}{2}$ miles), Pi-ehien-fang ( $1 \frac{1}{2}$ miles), Yang-ke-pa-er (3 miles), Ta-pu-na (or Nor) (5 miles), and Ta-he-he (5 miles).

NORTHERN ROUTE.

Stage 4. Su-chi (20 miles). General direction 


\section{APPENDIX}

North. On leaving T'ien-ch'êng-ts'uen the road bends to the north-west up a gradual ascent to a pass in a bluff on the edge of the T'ai Hai basin, then descends to Pa-ti-hsiah (inns) (5 miles), subsequently turning northward, skirting the eastern shore of the lake. It passes Ma-liut'ung (inns) ( 6 miles), Sha-tai-kou (6 miles), when it enters mountain valley and reaches $\mathrm{Su}$-chi, which place is composed of one large inn.

Stage 5. Sui-mo-chien (25 miles). General direction: W.N.W. The road turns westward up a side valley and crosses a steep pass ( 6 miles), descends into another valley passing Haoch'ien-shan (4 miles), and Wu-li-pa (2 miles; several inns). It then crosses another low pass and descends valley to Sui-mo-chien, passing Ta-la-pu-la (2 miles, pop. 1,000; several inns), Hung-sha-pa (3 miles), Ta-yu-ssŭ ( 3 miles, pop. 500 ; several inns).

Stage 6. Mei-tê-erh (18 miles). General direction: W.N.W. Road follows down valley and is easy going. It passes Ming-k'ou-mên ( 3 miles), Lang-tiao-tze ( $1 \frac{1}{2}$ miles), Ku-li-shih ( $1 \frac{1}{2}$ miles), Ku-chia-wan-tzŭ (3 miles), Shih-jên-wan (3 miles; good inn). Mei-tê-erh is just outside the mouth of the valley.

Stage 7. K'uei-hua-ch'êng (20 miles). General direction: W.N.W. The road erosses the plain and is easy going. It passes $\mathrm{Wu}$-lu (5 miles), Pa-tzŭ (4 miles), Tao-ho-lung (2 miles), Chiahsiang-yin-tzŭ (3 miles) and Tai-sung (3 miles). K'uei-hua-ch'êng: pop. 50,000; good inns. Important commercial centre. 


\section{APPENDIX}

I refrain from giving itineraries of our journey in Inner Mongolia, as unless the main high roads are followed there can be no ccrtainty about the stages and halting places. The Mongols shift their camps, as it suits them, and the traveller perforce pitches his own camp at the end of a day's run, wherever he can find a supply of water. We did not follow the main high road to Lama-Miao, so cannot give the stages.

Printed in Great Britain by Butler \& Tanner, Frome and London. 



Microtorncd by Preservation Services $\mathrm{mfm} \# 5570.0 \hat{y}$ 
SMITHSONIAN INSTITUTION LIBRARIES

||||||||||||||||||||||||||||||||||||||||||||||||||||||||||||||||||||||

39088 002074235 nhmamm DS710.S6X

Sport and science on the Sino-Mongolian 